LUIS FELIPE FERREIRA MENDONÇA CRUZ

\title{
AÇÕES AFIRMATIVAS E O PRINCÍPIO DA IGUALDADE
}

Dissertação apresentada à Faculdade de Direito da Universidade de São Paulo para a obtenção do título de Mestre em Direito.

Área de concentração: Direitos Humanos.

Orientador: Prof. Dr. Kabengele Munanga.

SÃO PAULO 


\section{FOLHA DE APROVAÇÃO}

CRUZ, Luis Felipe Ferreira Mendonça. Ações afirmativas e o princípio da igualdade. Dissertação (Mestrado) - Faculdade de Direito, Universidade de São Paulo, São Paulo, 2011.

Dissertação apresentada à Faculdade de Direito da Universidade de São Paulo para a obtenção do título de Mestre em Direito.

Área de concentração: Direitos Humanos.

Aprovado em:

Banca Examinadora:

Prof. Dr.:

Julgamento:

Instituição:

Assinatura:

Prof. Dr.:

Julgamento:

Instituição:

Assinatura:

Prof. Dr.:

Julgamento:

Instituição:

Assinatura: 


\section{AGRADECIMENTOS}

A Paula Ferreira Mendonça Cruz e Bruna Barbosa Silva, pela ajuda na transcrição de excertos e pela valiosa companhia.

A Felipe Albertini Nani Viaro, pela ajuda na busca de material e nas traduções.

Aos amigos do Rugby XI, por me manterem vivo e íntegro nos últimos anos!

Aos contribuintes paulistas do ICMS e a minha agência financiadora - meus pais pela oportunidade de poder me dedicar à pesquisa e à elaboração deste estudo.

Aos Professores Virgílio Afonso da Silva, Eunice Aparecida de Jesus Prudente e Dilma de Melo Silva, pelas pacientes atenções e preciosas sugestões.

E, sobretudo, ao Professor Kabengele Munanga, pela oportunidade de ser seu aluno - mesmo sem me conhecer pessoalmente - e pela ampla liberdade que me concedeu para desenvolver este estudo. 


\section{RESUMO}

CRUZ, Luis Felipe Ferreira Mendonça. Ações afirmativas e o princípio da igualdade. Dissertação (Mestrado) - Faculdade de Direito, Universidade de São Paulo, São Paulo, 2011.

Ao enunciado da igualdade pode-se atribuir corretamente dois princípios jurídicos: o princípio da igualdade fática e o princípio da igualdade jurídica. Esses princípios, todavia, estão frequentemente em colisão, configurando um aparente paradoxo. A partir da teoria dos princípios, por conferir aos princípios jurídicos o caráter de mandamentos de otimização, é possível solucionar o aparente paradoxo por meio da máxima da proporcionalidade. As medidas de ação afirmativa, por sua vez, visam a fomentar o princípio da igualdade fática ao mesmo tempo em que restringem o princípio da igualdade jurídica. Conquanto restrições a direitos fundamentais com a estrutura de princípio sejam possíveis, elas devem seguir a máxima da proporcionalidade. A aferição da constitucionalidade de medidas restritivas a princípios só é possível no caso concreto. Desse modo, as medidas de ação afirmativa são, em geral, um instrumento facultado ao Estado para perseguir fins constitucionalmente determinados independentemente dos critérios de diferenciação adotados.

Palavras-chave: Igualdade. Princípio. Ações Afirmativas. Direitos Fundamentais. 


\begin{abstract}
CRUZ, Luis Felipe Ferreira Mendonça. Affirmative action and the principle of equality. Dissertation (Master), Faculdade de Direito, Universidade de São Paulo, São Paulo, 2011.

To the statement of equality two legal principles can be correctly attributed: the principle of factual equality and the principle of legal equality. These principles, however, are frequently under collision, configuring an apparent paradox. From the theory of principles, as it confers to legal principles features of optimization commandments, it is possible to solve the apparent paradox through the proportionality maxim. Affirmative action measures, in turn, aim to foment the principle of factual equality at the same time that they restrict the principle of legal equality. Although restrictions to constitutional rights that have the structure of principles are possible, these restrictions must follow the proportionality maxim. Reviewing the constitutionality of measures restrictive to principles is only possible on a case by case basis. Therefore, affirmative action measures are, in general, an instrument granted to the State to pursue constitutionally determined goals, independently of the adopted differentiation criteria.
\end{abstract}

Keywords: Equality. Principle. Affirmative Action. Constitutional Rights. 


\section{LISTA DE SIGLAS E ABREVIATURAS}

ADI - Ação Direta de Inconstitucionalidade

ADPF - Arguição de Descumprimento de Preceito Fundamental

AgR - Agravo Regimental

AI - Agravo de Instrumento

CF - Constituição da República Federativa do Brasil

IBGE - Instituto Brasileiro de Geografia e Estatística

IPEA - Instituto de Pesquisa Econômica Aplicada

MI - Mandado de Injunção

RE - Recurso Extraordinário

REsp - Recurso Especial

STF - Supremo Tribunal Federal 


\section{SUMÁRIO}

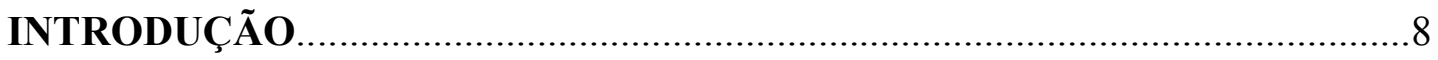

\section{CAPÍTULO 1 - DO PRINCÍPIO DA IGUALDADE}

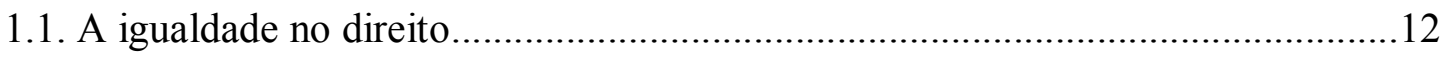

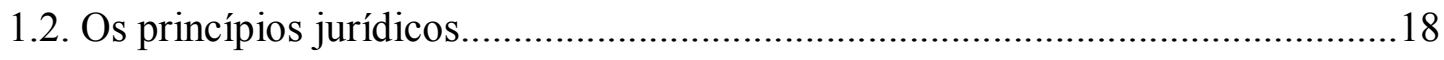

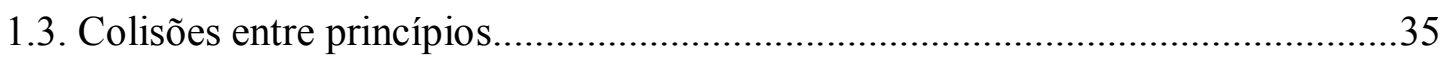

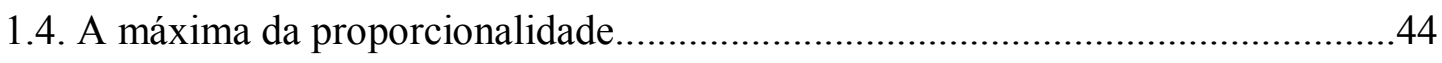

\section{CAPÍTULO 2 - DAS AÇÕES AFIRMATIVAS}

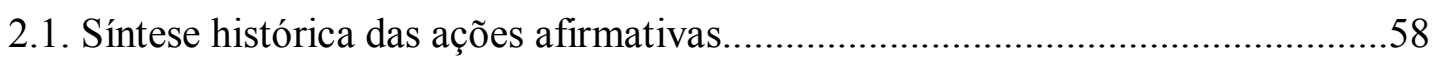

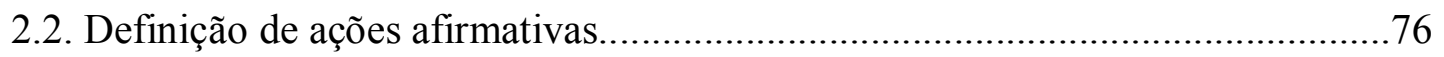

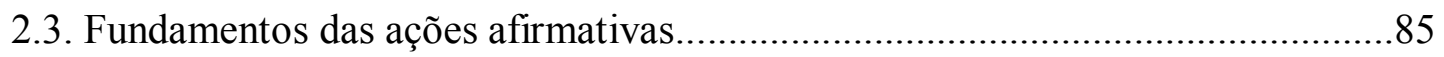

\section{CAPÍTULO 3 - AÇÕES AFIRMATIVAS E O PRINCÍPIO DA IGUALDADE}

3.1. Sobre a juridicidade das ações afirmativas no Brasil........................................94

3.2. Sobre a juridicidade do critério de diferenciação etnicorracial..........................101

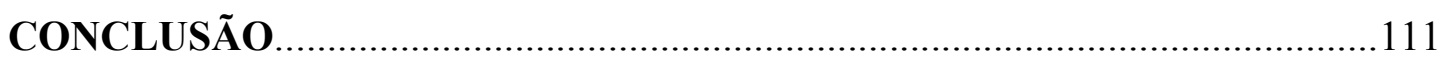

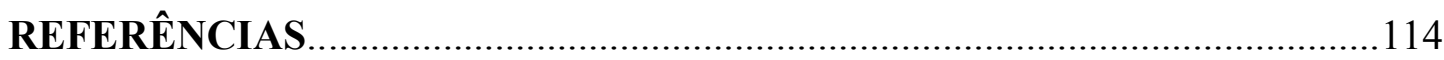




\section{INTRODUÇÃO}

Atualmente, o tema das ações afirmativas vem recebendo, no Brasil, grande atenção. Quer seja em razão da aplicação relativamente tímida e tardia desse gênero de políticas públicas, quer seja em razão da forte oposição que têm sofrido, os méritos das políticas de ação afirmativa estão longe de ser um consenso.

Conquanto seja tema polêmico, não é pouco o que já foi escrito sobre as ações afirmativas no Brasil: não se trata de um tema novo ou inédito no âmbito acadêmico. Sobre as políticas de ação afirmativa baseadas no fator etnicorracial, por exemplo, já há quem tenha feito análise sociológica do debate jurídico sobre o tema ${ }^{1}$ e quem tenha estudado o tema no direito comparado ${ }^{2}$; há, ainda, quem tenha discorrido acerca da impropriedade da adoção isolada desse critério de diferenciação no Brasil ${ }^{3}$ e há muitos que já defenderam sua possibilidade jurídica e sua adequação sociopolítica ${ }^{4}$.

No entanto, apesar dos inegáveis méritos e das incomensuráveis contribuições trazidos por todos os estudos feitos sobre as políticas de ação afirmativa, observa-se uma relativa superficialidade quanto à sua fundamentação jurídico-constitucional. Muitos autores, após discorrerem farta e brilhantemente sobre a história e sobre as características

\footnotetext{
${ }^{1}$ Cf., entre outros: MedeIros, Priscila Martins. "Raça” e Estado democrático: o debate sóciojurídico acerca das políticas de ação afirmativa no Brasil. Dissertação (mestrado em Sociologia), Centro de Educação e Ciências Humanas, Universidade Federal de São Carlos, São Carlos, 2005.

${ }^{2}$ Cf., entre outros: MenEzes, Paulo. Ação afirmativa (affirmative action) no direito norte-americano. São Paulo: Revista dos Tribunais, 2001.

${ }^{3}$ Cf., entre outros: KaUfmann, Roberta Fragoso Menezes. Ações afirmativas à brasileira: necessidade ou mito? Porto Alegre: Livraria do Advogado, 2007.

${ }^{4}$ Cf., entre outros: AtChABAHIAN, Serge. Principio da igualdade e ações afirmativas. São Paulo: RCS, 2004. RoDRIGUES, João Jorge Santos. Direito e ação afirmativa: as políticas de ação afirmativa para afrobrasileiros. Dissertação (mestrado em Direito e Estado), Faculdade de Direito, Universidade de Brasília, Brasília, 2005. VILAS-BÔAS, Renata Malta. Ações afirmativas e o princípio da igualdade. Rio de Janeiro: América Jurídica, 2003. Silva, Sidney Pessoa Madruga da. Discriminação Positiva: Ações Afirmativas na Realidade Brasileira. Brasília: Brasília Jurídica, 2005. SilvA, Maria do Socorro da. Ações afirmativas para a população negra: um instrumento para a justiça social no Brasil. Dissertação (mestrado em Direito), Faculdade de Direito, Universidade de São Paulo, São Paulo, 2009. GuERrini, Estela Waksberg. Ações afirmativas para negros nas universidades públicas brasileiras: o caso do Tribunal de Justiça do Rio de Janeiro (2001-2008). Dissertação (mestrado em Direito), Faculdade de Direito, Universidade de São Paulo, São Paulo, 2010.
} 
das políticas de ação afirmativa e após considerarem os méritos e deméritos, vantagens e desvantagens, sucessos e insucessos dessas políticas, concluem pela sua constitucionalidade - ou inconstitucionalidade - apenas citando dispositivos da CF (a exemplo de seu art. $3^{\circ}$ ou seu art. $5^{\circ}$ ), seu preâmbulo, ou dispositivos de Direito Internacional dos Direitos Humanos (a exemplo do art. $1^{\circ}, \S 4^{\circ}$ da Convenção Internacional sobre a Eliminação de Todas as Formas de Discriminação Racial) que sustentam a posição adotada, tomando por pouco problemática sua adequação - ou inadequação - ao sistema jurídico brasileiro. A fundamentação jurídico-constitucional das ações afirmativas exige maior profundidade.

A partir dessa constatação, o escopo do presente trabalho consiste em aprofundar a análise das políticas de ação afirmativa sob o prisma dos princípios constitucionais com o objetivo de complementar a fundamentação trazida pelos demais estudos sobre o tema. Uma dificuldade, contudo, se impõe: por conta da relativa novidade do tema ${ }^{5}$ no Brasil, pouco se discutiu a respeito da constitucionalidade de medidas de ação afirmativa no STF - não há sequer uma decisão definitiva quanto às políticas de ação afirmativa baseadas no recorte etnicorracial ${ }^{6}$. Portanto, em relação a outros temas, assumem maior relevância os fundamentos jurídicos trazidos pela doutrina e jurisprudência estrangeiras, que fornecem substratos úteis extraídos de sistemas jurídicos que, em muitos casos, se assemelham ao sistema brasileiro ou foram mesmo fontes diretas de inspiração ao constituinte de 1987.

Desse modo, o presente trabalho, utilizando-se de uma abordagem metodológica específica, busca melhor estruturar a fundamentação jurídico-constitucional das políticas de ação afirmativa, que, por sua vez, podem se tornar um importante instrumento para a mitigação de incontáveis e, muitas vezes, intoleráveis desigualdades - de diversos matizes - presentes na sociedade brasileira.

O trabalho a ser desenvolvido consiste, em brevíssimas palavras, na análise das políticas de ação afirmativa à luz da teoria dos princípios, que pode ser a chave para explicar a controversa questão da possibilidade jurídica da adoção desse gênero de políticas e sua compatibilidade com a CF.

Com a finalidade de delimitar o escopo da pesquisa e orientar as atividades necessárias ao desenvolvimento do tema, foram estabelecidas as seguintes hipóteses: (i) as

\footnotetext{
${ }^{5}$ Em relação a outros países, notoriamente em relação aos Estados Unidos da América.

${ }^{6}$ Isso não significa que o assunto não tenha sido discutido nas instâncias inferiores, mas apenas que não há uma decisão em sede de controle concentrado de constitucionalidade. Sobre o assunto, foram ajuizados a ADPF 186 e o RE 597.285/RS, pendentes de julgamento.
} 
políticas de ação afirmativa estão fundamentadas em princípios contidos na $\mathrm{CF}$ (em especial no princípio da igualdade fática); (ii) as políticas de ação afirmativa, para serem constitucionais, devem ser proporcionais, pois restringem direitos; (iii) as políticas de ação afirmativa, em geral, são um meio facultativo para fomentar a realização de princípios constitucionais (em especial do princípio da igualdade fática), mas não são um meio obrigatório nem proibido; (iv) a adoção (ou não) de políticas de ação afirmativa, se facultativas, é uma questão política, não encontrando respaldo jurídico apenas se as medidas forem desproporcionais; (v) o ônus argumentativo é de quem pretende o estabelecimento de políticas de ação afirmativa; e, por fim, (vi) os argumentos empíricos (sociológicos, econômicos, culturais, etc.), geralmente oriundos de fora do círculo jurídico, são, nesse caso, de particular interesse.

Este estudo foi estruturado em três capítulos. O primeiro capítulo, dedicado ao princípio da igualdade, é dividido em quatro seções. A primeira seção abordará a noção jurídica de igualdade: é um direito fundamental com a estrutura de princípio. A segunda seção tratará do núcleo da abordagem metodológica utilizada, que é a separação das normas jurídicas entre regras e princípios. Os pontos centrais serão a definição de princípio jurídico, o que é essencial para a coerência do trabalho, e a concomitante análise do enunciado da igualdade, seu significado e os possíveis princípios jurídico que a partir dele poderão ser refinados. Será demonstrada a coexistência de dois princípios jurídicos em constante colisão: o princípio da igualdade jurídica e o princípio da igualdade fática. A terceira seção consistirá em uma explicação sobre como ocorrem as colisões entre princípios e de que modo são solucionadas mediante o estabelecimento de relações condicionadas de precedência. Há, contudo, uma peculiaridade na colisão entre o princípio da igualdade fática e o princípio da igualdade jurídica: por conta de uma inerente assimetria, o ônus argumentativo recai sobre quem pretende estabelecer um tratamento jurídico desigual. Encerrando o primeiro capítulo, a quarta seção se destinará a explicar como se opera a máxima da proporcionalidade - modo de solução de colisões entre princípios.

O segundo capítulo é destinado às ações afirmativas: o que são, como surgiram e quais são suas finalidades. A primeira seção exporá um breve histórico desse gênero de política pública e sua previsão em atos normativos de diversos países. Na segunda seção será investigado o conceito de ações afirmativas, suas características e suas finalidades. Será conferido um significado mais amplo às ações afirmativas, já que são inúmeras as modalidades e critérios adotados, não se resumindo apenas a medidas que conferem 
vantagens a determinados grupos sociais. Por fim, a terceira seção, com base na relativamente farta bibliografia a respeito, descreverá as principais justificativas para a adoção das medidas de ação afirmativa, assim como serão expostos alguns argumentos contrários a elas.

O terceiro capítulo consiste na análise da possibilidade jurídica de adoção de políticas de ação afirmativa utilizando-se do instrumental oferecido pela teoria dos princípios. A primeira seção, portanto, será focada na possibilidade jurídica de adoção de medidas de ação afirmativa no Brasil. Como o espectro é bastante amplo, será observado que, em geral, as medidas de ação afirmativa são um meio possível para que o Estado fomente objetivos veiculados pela $\mathrm{CF}$, entre os quais a redução das desigualdades socioeconômicas, e que a análise da constitucionalidade de tais medidas não é possível em abstrato, mas tão somente caso a caso. Por fim, a segunda seção tratará de aplicar toda a teoria apreendida até então na solução de uma polêmica pergunta prática: é possível a adoção do critério etnicorracial como fator de diferenciação em medidas de ação afirmativa? 


\section{CAPÍTULO 1 - DO PRINCÍPIO DA IGUALDADE}

\subsection{A igualdade no direito}

A noção de igualdade entre os seres humanos não é uma descoberta contemporânea. Filósofos já se preocupavam com o tema, e suas implicações, séculos antes do início da era cristã. Foi com o cristianismo, contudo, que a igualdade entre os homens ganhou fôlego, sendo relevante objeto de preocupações na teologia ${ }^{7}$. No Iluminismo, as investigações sobre a igualdade adquiriram um cunho politizado, destinadas a transformar a sociedade. Nada de novo, portanto. Não obstante, há um aspecto das preocupações com a igualdade entre os seres humanos que é relativamente recente. Esse aspecto, que pertence à Idade Contemporânea - aliás, um dos marcos do início da Idade Contemporânea - constitui o tema da presente seção: a noção jurídica de igualdade.

As Revoluções Liberais do final do séc. XVIII trouxeram inúmeras mudanças, tanto políticas quanto sociais, econômicas e científicas, com reflexos em todas as áreas do conhecimento, inclusive no Direito. Na área jurídica, merecem destaque as declarações de direitos, sendo a declaração de 1789 - Declaração dos Direitos do Homem e do Cidadão a mais marcante. Tais documentos, fundamentados na noção de soberania popular, impuseram limites e condições ao exercício do poder, entre os quais a igualdade. Desse modo, a igualdade passou a integrar definitivamente o mundo jurídico ${ }^{8}$, sempre em posição de destaque.

Entre a pluralidade de sentidos do vocábulo "igualdade", portanto, há alguns eminentemente jurídicos. São esses sentidos que interessam ao presente estudo: para apreendê-los, far-se-á referências a dispositivos constitucionais, tratados internacionais e à

\footnotetext{
${ }^{7}$ Cf. Vilas-BôAs, Renata Malta. Ações afirmativas e o princípio da igualdade. Rio de Janeiro: América Jurídica, 2003, p. 3-16.

${ }^{8}$ Cf. Comparato, Fábio Konder. Igualdade, desigualdades. Revista trimestral de direito público, São Paulo, n. 1,1993, p. 76.
} 
doutrina, já que "[s]ignificações específicas no discurso jurídico devem ser obtidas a partir

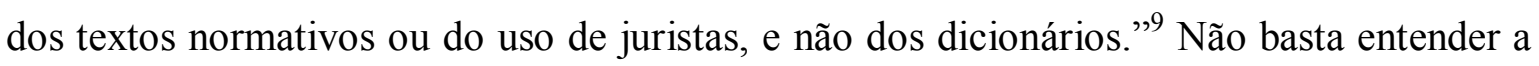
igualdade, para os fins propostos neste trabalho, como uma noção lógica, filosófica, teológica, sociológica ou econômica. Deve-se entender a igualdade como parte integrante de determinadas normas jurídicas.

A partir do momento em que a igualdade passou a figurar no rol de direitos fundamentais previstos nas constituições de diferentes Estados (direito positivo estatal), tornou-se possível qualificá-la como um típico direito fundamental - o direito à igualdade -, muito embora não haja um consenso sobre sua abrangência e suas características. De qualquer maneira, o direito à igualdade, desde suas mais remotas origens, sempre foi marcado, assim como qualquer dos direitos humanos, pela sua fundamentalidade. Não se quer dizer que o direito à igualdade sempre tenha sido um direito fundamental: só o foi considerado a partir da codificação dos direitos assegurados pelas diversas constituições nacionais e por instrumentos de Direito Internacional. Mesmo antes disso, desde o séc. XVIII, o direito à igualdade sempre foi marcado pela fundamentalidade, que nada mais é que a "[...] prioridade em todos os graus do sistema jurídico, portanto, também perante o dador de leis." ${ }^{10}$ A partir do exposto, percebe-se que a este trabalho subjaz o critério procedimental para se identificar um direito fundamental, critério que, embora não isento de críticas, se presta útil como ponto de partida. Direitos fundamentais não são apenas o que a constituição afirma o ser (critério formal), nem são os direitos humanos que foram positivados no ordenamento jurídico nacional (critério material); direitos fundamentais, no âmbito do direito interno, são aqueles que são considerados tão importantes que a opção entre garanti-los ou não garanti-los não pode nem deve ser "[...] confiada a las mayorías parlamentarias ordinarias [...]"11, ou, como ocorre no Brasil, sequer ao parlamento no exercício do poder constituinte derivado (art. 60, $\S 4^{\circ}$ da CF). Assim, "[e]1 criterio

\footnotetext{
${ }^{9}$ BArreto, Paulo Ayres. Contribuições: regime jurídico, destinação e controle. São Paulo: Noeses, 2008 , p. 33.

${ }^{10}$ AleXY, Robert. Constitucionalismo Discursivo. $2^{\mathrm{a}}$ ed. Tradução Luís Afonso Heck. Porto Alegre: Livraria do Advogado, 2008, p. 48.

${ }^{11}$ Borowski, Martin. La estructura de los derechos fundamentales. Tradução Carlos Bernal Pulido. Bogotá: Universidad Externado de Colombia, 2003, p. 37.
} 
procedimental está ligado a criterios formales y materiales [...]"12 e não exclui a existência de direitos fundamentais internacionais, como se verá adiante.

No direito brasileiro, o tratamento jurídico conferido à igualdade não seguiu caminho diferente. O direito à igualdade esteve previsto em todas as constituições brasileiras $^{13}$. Atualmente, pode-se dizer que o direito à igualdade, além de ser direito fundamental, é inclusive veiculado por enunciados topologicamente posicionados em destaque que abrem o art. $5^{\circ}$, caput da CF com a clássica expressão "todos são iguais perante a lei". Ademais, garante-se a "inviolabilidade do direito [...] à igualdade" e, por fim, especifica-se que "homens e mulheres são iguais em direitos e obrigações" (art. $\left.5^{\circ}, \mathrm{I}\right)$. Assim, o Brasil segue a tradição, inaugurada com a Constituição francesa de $1793^{14}$, de enunciar o direito à igualdade mediante a expressão "perante a lei", à semelhança da previsão constitucional na Lei Fundamental alemã (art. 3.1), na Constituição colombiana (art. 13), na Constituição espanhola (art. 14), na Constituição francesa (art. $1^{\circ}$ ), no Ato Constitucional do Canadá de 1982 (art. 15.1), entre outras. Essa semelhança é relevante justamente porque grande parte dos estudos sobre o direito à igualdade que servirão de suporte a este trabalho é oriunda de países estrangeiros que consagram o direito à igualdade exatamente nos mesmos termos. Assim, mais do que identidade de objeto, há identidade de enunciado.

Aqui é possível notar que se utiliza uma noção semântica de norma jurídica, pois se baseia na distinção entre a norma (objeto da ciência do Direito) e seu enunciado. Não se pretende discutir as inúmeras teorias que explicam a norma jurídica, o que seria uma grande fuga do escopo deste trabalho: o exame dogmático do direito fundamental à igualdade. Por ser um exame dogmático, visa-se ao estudo da contextura do direito enquanto sistema de normas, “[...] se nele existem ou não certos institutos, e de que modo tais institutos se relacionam com outros; o único caminho é a dogmática, que implica uma

\footnotetext{
12 BorowsKI, Martin. La estructura de los derechos fundamentales. Tradução Carlos Bernal Pulido. Bogotá: Universidad Externado de Colombia, 2003, p. 37.

${ }^{13}$ Para um histórico da positivação do direito à igualdade nas constituições brasileiras, confira: MELLO, Marco Aurélio Mendes de Farias. Óptica constitucional - a igualdade e as ações afirmativas. Revista de Direito Bancário, do Mercado de Capitais e da Arbitragem, São Paulo, a. 5, n. 15, p. 13-20, jan./mar. 2002, p. 13-15.
}

14 “Art. 3 Todos os homens são iguais pela natureza e perante a lei.” Cf. COMPARATO, Fábio Konder. A afirmação histórica dos direitos humanos. $2^{\mathrm{a}}$ ed. São Paulo: Saraiva, 2001, p. 155. 
análise intra-sistêmica [...]"15. A análise intrassistêmica, é importante mencionar, não significa, por sua vez, a exclusão dos conhecimentos oriundos das demais ciências. Significa servir-se deles apenas na medida em que esses conhecimentos sejam necessários para a própria operacionalização intrassistêmica do direito, principalmente no momento da argumentação jurídica para a fundamentação de juízos de dever-ser. Assim, pertencem à ciência do Direito “[...] los principios y los otros argumentos normativos en los que se apoya el procedimiento de la aplicación del derecho y/o tiene que apoyarse a fin de satisfacer la pretensión de corrección."16

Ainda por ser um exame dogmático, o trabalho será calcado na análise do direito vigente e se erguerá sobre pontos de partida - de pressupostos ${ }^{17}-$, sendo um deles a distinção entre enunciado e norma, compatível com as mais variadas teorias sobre a validade $^{18}$. Um enunciado que veicula uma norma jurídica é um enunciado normativo, que, enquanto construção linguística, deve ser interpretado ${ }^{19}$. Se a norma for um direito fundamental, os respectivos enunciados são enunciados normativos de direito fundamental ${ }^{20}$. Os enunciados que expressam o direito à igualdade, como já foi dito, se encontram principalmente no art. $5^{\circ}$, caput da CF. Desses enunciados é possível extrair, sem maiores dificuldades, o direito à igualdade, que pode ser assim formulado utilizandose de um dos operadores deônticos básicos (proibido, obrigatório e permitido): "é obrigatório que todos sejam iguais entre si", ou "é proibido que não sejam todos iguais entre si", ou, ainda, "todos devem ser iguais entre si". Assim está formulado o direito geral

\footnotetext{
${ }^{15}$ Carvalho, Paulo de Barros. Curso de Direito Tributário. $17^{\mathrm{a}}$ ed. São Paulo: Saraiva, 2005, p. 55. Ao autor atribui-se a noção de dogmática enquanto Ciência do Direito em sentido estrito.

${ }^{16}$ AleXY, Robert. El concepto y la validez del derecho. $2^{\mathrm{a}}$ ed. Tradução Jorge Seña. Barcelona: Gedisa, 2004, p. 123.

${ }^{17}$ Cf. Ferraz JR., Tercio Sampaio. Introdução ao estudo do direito: técnica, decisão, dominação. $4^{\mathrm{a}}$ ed. São Paulo: Atlas, 2003, p. 85. Ademais, deve-se ter em vista o objetivo deste trabalho (exposto na introdução) e a própria função da dogmática jurídica: “[a] dogmática dos direitos fundamentais, enquanto disciplina prática, visa, em última instância, a uma fundamentação racional de juízos concretos de dever-ser no âmbito dos direitos fundamentais." AlEXY, Robert. Teoria dos direitos fundamentais. Tradução Virgílio Afonso da Silva. São Paulo: Malheiros, 2008, p. 43.

${ }^{18}$ Cf. Alexy, Robert. Teoria dos direitos fundamentais. Tradução Virgílio Afonso da Silva. São Paulo: Malheiros, 2008, p. 52.

${ }^{19}$ Cf. Silva, Virgílio Afonso da. Princípios e regras: mitos e equívocos acerca de uma distinção. Revista Latino-Americana de Estudos Constitucionais, Belo Horizonte, n.1, p. 607-630, jan./jul. 2003, p. 616.

${ }^{20}$ Cf. AleXY, Robert. Teoria dos direitos fundamentais. Tradução Virgílio Afonso da Silva. São Paulo: Malheiros, 2008, p. 66.
} 
de igualdade, estabelecido diretamente de enunciados normativos de direito fundamental, pois para apreendê-lo basta uma análise perfunctória dos enunciados referência.

A existência de direitos fundamentais diretamente estabelecidos, contudo, não exclui a possibilidade de que outras normas de direito fundamental sejam atribuídas a partir dos mesmos enunciados por meio de um refinamento. Uma norma de direito fundamental atribuída “[...] é válida, e é norma de direito fundamental, se para tal atribuição a uma norma diretamente estabelecida pelo texto constitucional, for possível uma correta fundamentação referida a direitos fundamentais." 21

Convém notar que, paralelamente ao front interno de positivação dos direitos humanos em direitos fundamentais, e de forma não menos importante, a positivação dos direitos humanos em direitos fundamentais também se deu no front externo. Assim, o direito à igualdade também não é estranho ao Direito Internacional, sendo previsto em inúmeros instrumentos. A Declaração Universal dos Direitos Humanos, de 1948, prevê o direito à igualdade ao afirmar que todos " [...] nascem livres e iguais em dignidade e direitos" (art. $1^{\circ}$ ). O Pacto Internacional de Direitos Civis e Políticos de 1966 (ratificado pelo Brasil em 1992) prevê o direito geral de igualdade pela fórmula "todas as pessoas são iguais perante a lei e têm direito, sem discriminação alguma, a igual proteção da lei” (art. 26). Trata-se de uma interessante mescla entre a tradição europeia de enunciar o direito à igualdade mediante a fórmula "perante a lei" e a fórmula norte-americana da equal protection $^{22}$. Assim, o direito à igualdade integra $\mathrm{o}$ rol de direitos fundamentais internacionais:

Los derechos fundamentales internacionales son derechos que han sido
consagrados en los pactos y convenciones internacionales para la protección de
los derechos humanos. Estos derechos constituyen el intento de transformar los
derechos humanos en derecho positivo. [...] Entre los pactos y convenciones de
validez mundial deben mencionarse ante todo la Declaración Universal de
Derechos Humanos de 10 de diciembre de $1948[\ldots] .{ }^{23}$

${ }^{21}$ Alexy, Robert. Teoria dos direitos fundamentais. Tradução Virgílio Afonso da Silva. São Paulo: Malheiros, 2008, p. 74.

22 "No State shall make or enforce any law which shall abridge the privileges or immunities of citizens of the United States; nor shall any State deprive any person of life, liberty, or property, without due process of law; nor deny to any person within its jurisdiction the equal protection of the laws." Amendment XIV. Disponível em <http://www.archives.gov/exhibits/charters/constitution_amendments_11-27.html>. Acesso em: 4 de setembro de 2010.

${ }^{23}$ BorowsKi, Martin. La estructura de los derechos fundamentales. Tradução Carlos Bernal Pulido. Bogotá: Universidad Externado de Colombia, 2003, p. 31-32. 
Logo, no discurso jurídico, e levando-se em conta o direito vigente no Brasil, a igualdade é um direito fundamental. E, mais ainda, é um direito fundamental com a estrutura de princípio.

Conquanto o vocábulo "princípio" seja altamente polissêmico mesmo no interior do discurso jurídico, parece ser unânime a inclusão do direito à igualdade na categoria dos princípios jurídicos. A razão mais importante para a unanimidade consiste no fato de que, qualquer que seja a definição de princípio adotada, o direito à igualdade estará incluído entre os princípios. A título de exemplo, a partir da definição de princípio mais utilizada no Brasil - que seriam as normas jurídicas mais importantes de um ordenamento jurídico ${ }^{24}$-, não haveria nenhum problema em se enquadrar o direito à igualdade na categoria, já que se trata de uma norma de suma importância que dirige a aplicação das demais normas. É curioso notar que, enquanto a inclusão do direito à igualdade na categoria de princípio não é problemática, a própria definição da categoria é altamente problemática.

Desse modo, levando-se em consideração que o uso indiscriminado de palavras polissêmicas, ou "palavras camaleônicas" 25 , pode prejudicar o rigor metodológico das investigações científicas ${ }^{26}$, em especial quanto a sua fundamentação, deve-se tratar do conceito de "princípio" que será utilizado no decorrer deste trabalho. Esse será o tema da próxima seção.

\footnotetext{
${ }^{24}$ J. Silva, C. Mello, L. Barroso, J. Canotilho e J. Raz, por exemplo, utilizam a palavra "princípio" nesse sentido. Cf. Silva, Virgílio Afonso da. Direitos fundamentais: conteúdo essencial, restrições e eficácia. $2^{\mathrm{a}}$ ed. São Paulo: Malheiros, 2010, p. 44.

${ }^{25}$ Cf. Alexy, Robert. Teoria dos direitos fundamentais. Tradução Virgílio Afonso da Silva. São Paulo: Malheiros, 2008, p. 45.

${ }^{26}$ Cf. Silva, Virgílio Afonso da. A constitucionalização do direito: os direitos fundamentais nas relações entre particulares. São Paulo: Malheiros, 2008, p. 35.
} 


\subsection{Os princípios jurídicos}

Como já foi exposto, não há dúvidas quanto ao caráter principiológico do direito à igualdade. A palavra "princípio", por sua vez, mesmo no interior do discurso jurídico, tem inúmeros significados. Esta seção tratará basicamente desses temas.

Inicialmente, deve-se ter em mente que uma norma jurídica, qualquer que seja sua hierarquia, ou é uma regra ou é um princípio ${ }^{27}$. Regra e princípio são espécies do gênero norma $^{28}$ e uma norma nunca poderá ser uma regra e um princípio ao mesmo tempo ${ }^{29}$. Cabe analisar quais são os critérios utilizados para essa diferenciação, configurando uma tese da separação rigorosa entre regras e princípios.

Muitas são as propostas de critérios para se diferenciar as regras dos princípios. No Brasil, prevalece a ideia segundo a qual os princípios são as normas mais importantes do ordenamento jurídico ${ }^{30}$, normas que, segundo P. CARVALHO, portam “[...] núcleos significativos de grande magnitude influenciando visivelmente a orientação de cadeias normativas $[\ldots]^{\prime 31}$. Na Alemanha, por seu turno, alguns autores procuram diferenciar as regras dos princípios a partir do grau de generalização e de abstração da norma ou de seu fundamento de validade (J. EsSER, E. Forsthoff, K. LARENZ, H. WOLFF e O. BACHOF). Outros, a partir da explicitude de seu conteúdo axiológico (C. CANARIS). Por fim, muitos autores de inspiração anglo-saxônica entendem que a diferença entre regras e princípios deriva do modo de aplicação da norma: as regras se aplicam no "tudo-ou-nada" e o eventual conflito entre regras é resolvido na dimensão da validade; já os princípios

${ }^{27}$ Cf. AleXY, Robert. Teoria dos direitos fundamentais. Tradução Virgílio Afonso da Silva. São Paulo: Malheiros, 2008, p. 91.

${ }^{28}$ Cf. Silva, Virgílio Afonso da. Princípios e regras: mitos e equívocos acerca de uma distinção. Revista Latino-Americana de Estudos Constitucionais, Belo Horizonte, n.1, p. 607-630, jan./jul. 2003, p. 607.

${ }^{29}$ Cf. Borowski, Martin. La estructura de los derechos fundamentales. Tradução Carlos Bernal Pulido. Bogotá: Universidad Externado de Colombia, 2003, p. 48.

${ }^{30}$ Cf. SILVA, Virgílio Afonso da. Direitos fundamentais: conteúdo essencial, restrições e eficácia. $2^{\mathrm{a}}$ ed. São Paulo: Malheiros, 2010, p. 44.

${ }^{31}$ Carvalho, Paulo de Barros. Direito Tributário, Linguagem e Método. $3^{\mathrm{a}}$ ed. São Paulo: Noeses, 2009, p. 268. 
consistem em fundamentos que devem ser conjugados com outros (R. DWORKIN) ou em mandamentos de otimização (R. ALEXY) ${ }^{32}$ e a eventual colisão entre princípios é resolvida na dimensão do peso, mediante sopesamento. O último critério apresentado será a base deste trabalho.

Escolher o critério de diferenciação entre regras e princípios é de suma importância principalmente em uma exposição sobre direitos fundamentais de caráter principiológico. Essa importância não se resume à eliminação de ambiguidades na utilização dos termos. Mais além, essa definição de princípio não implica uma mera diferença de denominação, mas uma diferença do próprio objeto. Adotar a noção de princípio como mandamento de otimização, como é a proposta de R. ALEXY, traz profundas implicações quanto à interpretação e à atribuição de direitos fundamentais, como alerta E. BÖCKENFÖRDE:

\begin{abstract}
Hans Huber ha llamado ya tempranamente la atención sobre el hecho de que la necesidad de concretización de los derechos fundamentales - entendidos como normas de principio - que resulta de su validez universal, de su amplitud e indeterminación no puede confundirse con la necesidad de interpretación. No sería una interpretación tradicional, sino más bien un fenómeno jurídico-creativo que va más allá de la interpretación, 'más atribución de sentido que aclaración de sentido', en cierto modo una atribución de contenido 'desde fuera ${ }^{33}$
\end{abstract}

A teoria dos princípios foi delineada, na Alemanha, principalmente por R. ALEXY e M. Borowski, e, no Brasil, por V. SILVA. Atribui-se, contudo, a R. DwORKIN a proposta de diferenciação entre regras e princípios a partir de um critério qualitativo. Afirma esse autor que "[a] diferença entre princípios jurídicos e regras jurídicas é de natureza lógica. [...] As regras são aplicáveis à maneira do tudo-ou-nada." ${ }^{34}$ Para melhor ilustrar o que R. DWORKIN sustenta, far-se-á referência ao seguinte exemplo: uma norma que determina que as reuniões de uma companhia devem se iniciar às 9 da manhã. Essa norma é uma regra porque ou é aplicada em sua totalidade - a reunião se iniciou às 9 horas - ou não é aplicada em sua totalidade - a reunião não se iniciou no horário devido. Isso não significa que as regras não podem comportar exceções: é perfeitamente possível que haja outra regra que

\footnotetext{
${ }^{32}$ Cf. Ávila, Humberto. A distinção entre princípios e regras e a redefinição do dever de proporcionalidade. Revista Diálogo Jurídico, Salvador, a. 1., n. 4, jul. 2001. Disponível em: <http://www.direitopublico.com.br/ pdf_4/DIALOGO-JURIDICO-04-JULHO-2001-HUMBERTO-AVILA.pdf $>$. Acesso em: 29 de outubro de 2009, p. 5-10.

${ }^{33}$ BöCKENFÖRDE, Ernst-Wolfgang. Escritos sobre Derechos Fundamentales. Tradução Juan Luis Requejo Pagés e Ignacio Villaverde Menéndez. Baden-Baden: Nomos, 1993, p. 127.

34 Dworkin, Ronald. Levando os direitos a sério. Tradução Nelson Boeira. São Paulo: Martins Fontes, 2002 , p. 39.
} 
determina que, nos dias de chuva, por exemplo, as reuniões devam se iniciar às 10 horas. Contudo, a regra só será completa se for enunciada juntamente com sua exceção, pois, segundo R, DWORKIN, as exceções compõem a regra: "as reuniões da companhia deverão se iniciar às 9 horas, exceto nos dias de chuva, hipótese em que deverão se iniciar às 10 horas". Um eventual conflito entre regras, por sua vez, ou é resolvido mediante a inclusão de uma exceção ou mediante a declaração de invalidade de uma das regras. Suponha-se que, na companhia imaginária, exista a já mencionada regra segundo a qual as reuniões devem se iniciar às 9 horas, mas haja outra regra que determina que as reuniões só poderão ser realizadas no período da tarde: nesse caso, por não ser possível abrir uma exceção, fatalmente uma das regras deverá ser considerada inválida - pois não há gradação na validade: uma regra não é "mais válida" que outra - utilizando-se qualquer um dos critérios de resolução de conflitos entre regras, como o critério da lex posterior derogat priori ou o critério da lex superior derogat inferiori. Percebe-se, então, o caráter binário, não graduado, das regras:

\begin{abstract}
The rule thus establishes a borderline - precise or vague - between the obligatory and not obligatory, the forbidden and permitted etc. If an action or a state of affairs is on the right side of the borderline, the norm is obeyed, no matter how close to the limit it is. [...] An important property of this mode of qualification is its binary, either-or, 0 -or-1 character. ${ }^{35}$
\end{abstract}

R. ALEXY concorda com a distinção entre regras e princípios baseada em um critério qualitativo, ou seja, baseada em qualidades estruturais das normas. Também concorda com a ideia segundo a qual as regras são aplicadas no "tudo-ou-nada" e que conflitos entre regras são resolvidos na dimensão da validade ${ }^{36}$. Contudo, vai além da teoria de R. DWORKIN ao propor que os princípios jurídicos sejam mandamentos de otimização.

Afirmar que um princípio jurídico é um mandamento de otimização significa dizer que deve ser realizado na maior medida possível, dentro das possibilidades fáticas e jurídicas existentes $^{37}$, ao contrário do que ocorre com as regras, que são mandamentos

\footnotetext{
${ }^{35}$ PeCZENIK, Aleksander. On Law and Reason. Dordrecht: Springer, 2008, p. 62.

${ }^{36}$ Cf. Alexy, Robert. Direito, Razão, Discurso: Estudos para a filosofia do direito. Tradução Luís Afonso Heck. Porto Alegre: Livraria do Advogado, 2010, p. 140.

37 Cf. AleXY, Robert. Teoria dos direitos fundamentais. Tradução Virgílio Afonso da Silva. São Paulo: Malheiros, 2008, p. 90.
} 
definitivos ${ }^{38}$. As possibilidades fáticas dizem respeito àquilo que é fisicamente possível, que pode ser realizado no mundo físico; as possibilidades jurídicas, por sua vez, são determinadas pelas normas jurídicas colidentes, em especial outros princípios. Diferenciam-se os princípios das regras pela sua estrutura, que pressupõe limitações à realização plena, pois nunca - ou quase nunca - as possibilidades fáticas e jurídicas serão ótimas no sentido de permitir a total realização de um princípio jurídico. Os princípios são, por conta de sua estrutura, necessariamente limitáveis, ao contrário das regras, que não podem ser limitadas, mas definitivamente aplicadas ou não aplicadas ${ }^{39}$.

Retornando-se ao exemplo da companhia imaginária, suponha-se que exista uma norma que determine que as reuniões devem se iniciar cedo. Essa norma é um princípio, pois o que determina deve ser realizado na maior medida possível e, portanto, pode ser objeto de sopesamento. Em suma, a norma é um princípio porque determina que as reuniões devem se iniciar o mais cedo possível, dadas as possibilidades jurídicas e fáticas possíveis. Suponha-se que exista outra norma que determina que a companhia deve assegurar um ambiente de trabalho saudável. Essa norma também é um princípio, pois determina que o ambiente de trabalho deve ser o mais saudável possível e pode ser sopesada. Logo se percebe que ambos os princípios descritos podem entrar em colisão: suponha-se que um diretor agendou uma reunião para as 6 horas da manhã, fundamentando sua decisão no princípio segundo o qual as reuniões devem se iniciar o mais cedo possível. Certamente muitos funcionários recorrerão ao presidente da companhia alegando que essa decisão do diretor não é razoável porque, entre outras razões, não é saudável estar presente tão cedo no ambiente de trabalho, já que terão sono durante o restante do expediente e, portanto, poderão ocorrer acidentes de trabalho. Nesse caso imaginário é claro que a decisão do presidente, qualquer que seja ela, não considerará inválido um dos princípios. Ao contrário, a decisão considerará os princípios válidos, mas, no caso em tela, um dos princípios deverá prevalecer sobre outro, pois teria mais "importância" ou maior "peso". Tudo isso é sucintamente resumido por R. ALEXY da seguinte maneira:

\footnotetext{
${ }^{38}$ Cf. AlEXY, Robert. Tres escritos sobre los derechos fundamentales y la teoría de los princípios. Tradução Carlos Bernal Pulido. Bogotá: Universidad Externado de Colombia, 2003, p. 96.

39 "Si una norma que asegura un derecho es tomada como una regla, entonces ese derecho es necesariamente un derecho no limitable. Si, no obstante, se trata de un principio, el derecho es necesariamente limitable." BoROWSKI, Martin. La restricción de los derechos fundamentales. Tradução Rodolfo Arango. Revista Española de Derecho Constitucional, Madrid, a. 20, n. 59, p. 29-56, mayo/agosto 2000, p. 39.
} 
Se dois princípios colidem - o que ocorre, por exemplo, quando algo é proibido de acordo com um princípio e, de acordo com o outro, permitido -, um dos princípios terá que ceder. Isso não significa, contudo, nem que o princípio deva ser declarado inválido, nem que nele deverá ser introduzida uma cláusula de exceção. $\mathrm{Na}$ verdade, o que ocorre é que um dos princípios tem precedência em face do outro sob determinadas condições. ${ }^{40}$

Os princípios, dessa forma, além da dimensão da validade, possuem uma dimensão que as regras não têm: a dimensão do peso ${ }^{41}$. Neste ponto, R. DwORKIN e R. ALEXY concordam $^{42}$ : a dimensão do peso ou da importância aparece, na colisão entre dois ou mais princípios, quando o princípio com maior peso relativo ou importância relativa, naquele caso, prevalece, sem que o princípio preterido perca sua validade ou que, em outros casos, inclusive prevaleça. Há, assim, tantas relações de precedência quantos forem os casos concretos em que há colisão entre princípios. É por isso que se fala em relação condicionada de precedência, pois é uma relação de precedência que se fixa apenas naquelas condições.

A resolução de colisões entre princípios pode se dar pelo sopesamento: deve-se sopesar os princípios eventualmente colidentes determinando-se, no caso concreto, qual tem maior peso. Assim, não se aplica um princípio a certos casos e em certas circunstâncias em favor de outro princípio sem que aquele deixe de ser válido e de integrar o ordenamento jurídico. O princípio afastado, por sua vez, poderá ser aplicado a outros casos e em outras circunstâncias afastando inclusive o princípio que o superara. O peso dos princípios é estabelecido casuisticamente, portanto, e o afastamento de um princípio não significa que tenha perdido sua validade enquanto norma jurídica. Por essa razão, M. BOROWSKI afirma que o fator de diferenciação entre regras e princípios é a capacidade de a norma ser objeto de ponderação ( = sopesamento):

Por su parte, la cuestión de si una norma de derecho fundamental representa una regla o un principio, puede ser solucionada mediante la pregunta de su capacidad

40 AlEXY, Robert. Teoria dos direitos fundamentais. Tradução Virgílio Afonso da Silva. São Paulo: Malheiros, 2008, p. 93.

${ }^{41}$ Cf. Dworkin, Ronald. Levando os direitos a sério. Tradução Nelson Boeira. São Paulo: Martins Fontes, 2002 , p. 42.

${ }^{42}$ Cf. AleXY, Robert. Direito, Razão, Discurso: Estudos para a filosofia do direito. Tradução Luís Afonso Heck. Porto Alegre: Livraria do Advogado, 2010, p. 141. 
para ser ponderada. Si una norma puede ser objeto de la ponderación en el caso concreto, entonces necesariamente se trata de un principio. ${ }^{43}$

Ademais, G. MANIACI aduz que o critério essencial para se distinguir regra de princípio é a possibilidade de sopesamento ${ }^{44}$ : não se busca o método de resolução das antinomias a partir da constatação de serem as normas envolvidas regras ou princípios, mas justamente se constata se as normas são regras ou princípios a partir de como a antinomia será resolvida - se na dimensão da validade ou do peso.

Neste ponto, passa-se à análise do direito à igualdade enquanto princípio. Qualquer aproximação ao enunciado da igualdade deve enfrentar sua estrutura semântica e estrutural aberta $^{45}$, o que provocou inúmeras discussões doutrinárias e jurisprudenciais quanto ao seu "alcance", "conteúdo", "sentido" ou "significado". Por muito tempo entendeu-se que o enunciado da igualdade significava o dever de se aplicar as normas jurídicas sem considerações pessoais, ou seja, a igualdade seria dirigida à aplicação da lei. Na defesa dessa noção, E. FORSTHOFF afirma que estender-se a igualdade à criação da lei conduziria a grave insegurança jurídica, já que “[...] para las apelaciones a una supuesta lesión del principio de la igualdad no existe ningún punto final." 46

Contudo, limitar-se ao entendimento segundo o qual o enunciado da igualdade se dirige à aplicação da lei é inócuo porque, ao exigir que “[...] toda norma jurídica seja aplicada a todos os casos que sejam abrangidos por seu suporte fático, e a nenhum caso que não o seja, nada mais significa que dizer que as normas jurídicas devem ser cumpridas." ${ }^{, 47}$ O tribunal constitucional alemão, por sua vez, assumiu que o enunciado da igualdade não diz respeito apenas à aplicação da lei, mas também à criação da lei: todos devem ser

\footnotetext{
${ }^{43}$ Borowski, Martin. La estructura de los derechos fundamentales. Tradução Carlos Bernal Pulido. Bogotá: Universidad Externado de Colombia, 2003, p. 108.

${ }^{44}$ Cf. MANIACI, Giorgio. Algunas notas sobre coherencia y balance en la teoría de Robert Alexy. Tradução José Juan Moreso. Isonomía, México, n. 20, p. 137-177, abr. 2004, p. 144.

45 Cf. AleXY, Robert. Teoria dos direitos fundamentais. Tradução Virgílio Afonso da Silva. São Paulo: Malheiros, 2008, p. 70-71.

${ }^{46}$ Forsthoff, Ernst. El Estado de la sociedad industrial. Tradução Luis López Guerra e Jaime Nicolás Muñiz. Madrid: Instituto de Estudios Políticos, 1975, p. 228.

47 AleXY, Robert. Teoria dos direitos fundamentais. Tradução Virgílio Afonso da Silva. São Paulo: Malheiros, 2008, p. 394. No mesmo sentido, cf. BERlin, Isaiah. Equality. Proceedings of the Aristotelian Society, London, new series v. 56, p. 321-326, 1955/1956, p. 306.
} 
tratados de forma igual pelo legislador ${ }^{48}$. O STF entende que o enunciado da igualdade vincula todas as instâncias de poder ${ }^{49}$, o que abrange o legislador, que tem o dever de tratar todos de forma igual - o que o tribunal denomina de igualdade na elaboração da lei ${ }^{50}$.

Ordenar que todos sejam tratados de forma igual pelo legislador não pode, contudo, significar que o legislador deva colocar todos na mesma posição jurídica, sob pena de criar normas sem sentido (ex: penas para todos, e não apenas para criminosos). Também não pode significar a exigência de que todos sejam iguais em todas as características naturais ou condições de fato (ex: todos devem ter cor dos olhos iguais, o que seria impossível):

Portanto, o enunciado geral de igualdade, dirigido ao legislador, não pode exigir que todos sejam tratados exatamente da mesma forma ou que todos devam ser iguais em todos os aspectos. Por outro lado, para ter algum conteúdo, ele não pode permitir toda e qualquer diferenciação e toda e qualquer distinção. ${ }^{51}$

A chave para a compreensão do enunciado da igualdade se encontra não na proibição de quaisquer diferenciações nem na possibilidade de quaisquer diferenciações, mas na fundamentação do tratamento jurídico desigual:

Quando o art. 5, caput, determina a fórmula clássica, que todos os homens diante da lei são iguais, para o Brasil, então isso não significa que não pode ser diferenciado. Essa prescrição não prescreve, por exemplo, que pobres e ricos devam pagar impostos no mesmo montante. Isso mostra que diferenciações são permitidas se para elas existem fundamentos razoáveis. ${ }^{52}$

Configura-se, assim, um sistema que ordena o tratamento jurídico igual, obrigatório, mas que pode ser afastado nos casos em que haja fundamentos razoáveis e corretos baseados em outros princípios constitucionais. Há, assim, uma assimetria entre o tratamento jurídico igual, que é o exigido via de regra, e o tratamento jurídico desigual, que é possível apenas em determinados casos:

${ }^{48}$ Cf. AleXY, Robert. Teoria dos direitos fundamentais. Tradução Virgílio Afonso da Silva. São Paulo: Malheiros, 2008, p. 395-396.

${ }^{49}$ Cf. AgR no AI 360.461/MG.

${ }^{50}$ Cf. MI 58/DF.

51 AleXy, Robert. Teoria dos direitos fundamentais. Tradução Virgílio Afonso da Silva. São Paulo: Malheiros, 2008, p. 396-397.

52 AleXY, Robert. Constitucionalismo Discursivo. $2^{\mathrm{a}}$ ed. Tradução Luís Afonso Heck. Porto Alegre: Livraria do Advogado, 2008, p. 51. 
A assimetria entre a norma de tratamento igual e a norma de tratamento desigual tem como conseqüência a possibilidade de compreender o enunciado geral de igualdade como um princípio da igualdade, que prima facie exige um tratamento igual e que permite um tratamento desigual apenas se isso for justificado por princípios contrapostos. ${ }^{53}$

A vedação da arbitrariedade significa que não se pode adotar um critério injustificado como fator de diferenciação. Em outras palavras, a diferenciação deve ser corretamente fundamentada, isto é, baseada em um discurso jurídico racional ${ }^{54}$. Se houver razões suficientes para um tratamento jurídico desigual, então não haverá arbítrio. Salientese que as razões devem ser apenas suficientes à admissão de um tratamento jurídico desigual - razões plausíveis - ainda que essa solução não seja a "melhor" ou a "mais justa" ${ }^{, 55}$.

Embora a exigência de justificação seja essencial para se entender o enunciado da igualdade, este não se reduz àquele. Não há como sustentar, como já fez o $\mathrm{STF}^{56}$, que o enunciado da igualdade é apenas a vedação da arbitrariedade, pois o exame da igualdade deixaria de sê-lo: exige-se que o exame da arbitrariedade seja conjugado com o exame da igualdade, o que exige a formação de pares de comparação ${ }^{57}$, afinal, a análise da igualdade é uma análise necessariamente comparativa ${ }^{58}$. Em outras palavras, o tratamento desigual arbitrário é aquele não devidamente fundamentado e, como qualquer restrição a um direito fundamental com o caráter de princípio deve ser fundamentado, não se estará diante de uma restrição legítima, mas de uma autêntica violação ao princípio vulnerado. Assim, a análise apenas de eventual arbitrariedade não se confunde com a análise da intervenção no dever de tratamento igual, embora deva integrar essa análise da mesma forma que deve

53 AleXY, Robert. Teoria dos direitos fundamentais. Tradução Virgílio Afonso da Silva. São Paulo: Malheiros, 2008, p. 411.

${ }^{54}$ Cf. AlEXY, Robert. Teoria da argumentação jurídica. Tradução Zilda Hutchinson Schild Silva. São Paulo: Landy, 2001, p. 211 et seq.

55 Cf. Alexy, Robert. Teoria dos direitos fundamentais. Tradução Virgílio Afonso da Silva. São Paulo: Malheiros, 2008, p. 413. No mesmo sentido, Bundesverfassungsgerichtsentscheidung 26 (302) (Einkommensteuergesetz), traduzido em: ScHWABE, Jürgen; MARTINS, Leonardo. Cinqüenta Anos de Jurisprudência do Tribunal Constitucional Alemão. Tradução Beatriz Hennig et. al. Berlin: Konrad Adenauer Stiftung, 2005, p. 323.

${ }^{56}$ AI 207.130-1/SP, fundamentado em MELlo, Celso Antônio Bandeira de. O conteúdo jurídico do princípio da igualdade. $3^{\mathrm{a}}$ ed. São Paulo: Malheiros, 1998, p. 18.

57 Cf. AleXy, Robert. Teoria dos direitos fundamentais. Tradução Virgílio Afonso da Silva. São Paulo: Malheiros, 2008, p. 401-402.

${ }^{58}$ Cf. Atchabahian, Serge. Princípio da igualdade e ações afirmativas. São Paulo: RCS, 2004, p. 18. 
integrar a análise de qualquer intervenção em princípios, vinculando-se o " [...] exame de arbitrariedade a dispositivos de direitos fundamentais específicos [... $]^{, 59}$.

Assim, delineia-se o seguinte plano: o tratamento igual é obrigatório se não houver razões suficientes para o tratamento desigual. Há um ônus argumentativo para o tratamento desigual, que não é, em si e por si só, absolutamente proibido. Resta saber que o tratamento igual ou desigual podem se referir tanto aos atos (igualdade jurídica) quanto às consequências (igualdade fática).

A igualdade jurídica, por se referir aos atos, assemelha-se ao que K. HESSE chama de "igualdade jurídica material": "[...] casos iguais devem encontrar regra igual." "60 Ou seja, fatos iguais devem receber a mesma normatização. Afirma o autor que os fatos serão iguais apenas em relação a certas características admitidas como relevantes, mas jamais em relação a todas, o que configuraria identidade de casos; convém abstrair-se das características não essenciais $^{61}$. A normatização semelhante para os fatos iguais é um ato do Estado, daí se diz que a igualdade jurídica é referente aos atos. Trata-se de um dever eminentemente negativo, pois exige uma abstenção do Estado - a abstenção de estabelecer normatizações distintas a casos iguais -, motivo pelo qual pode ser chamada de "igualdade negativa" ou "igualdade formal". Um exemplo é útil para ilustrar o que se pretende afirmar: uma lei que determine que todos paguem a mesma alíquota de imposto de renda por exemplo, $20 \%$ - seguiria impecavelmente a igualdade jurídica, pois tanto ricos como pobres serão tratados exatamente da mesma maneira, sem considerações quanto ao nível de riqueza de cada um, na medida em que pagam o imposto na mesma proporção.

Pode-se, contudo, objetar a tal atitude juridicamente igualitária do legislador argumentando-se que as consequências da lei tributária em questão serão desiguais: os ricos não teriam seu nível de vida significativamente afetado pelo pagamento do tributo, pois deixariam de consumir apenas certos bens supérfluos, ao passo que os pobres teriam seu nível de vida significativamente piorado, inclusive quanto ao acesso a artigos de

\footnotetext{
${ }^{59}$ AleXY, Robert. Teoria dos direitos fundamentais. Tradução Virgílio Afonso da Silva. São Paulo: Malheiros, 2008, p. 401.

${ }^{60}$ Hesse, Konrad. Elementos de Direito Constitucional da República Federal da Alemanha. Tradução Luís Afonso Heck. Porto Alegre: Sergio Antonio Fabris, 1998, p. 330. No excerto, a palavra "regra" não se refere ao conceito de regra enquanto mandamento definitivo, conforme a distinção feita neste trabalho; seria melhor interpretada como "norma" ou "normatização".

${ }^{61}$ Hesse, Konrad. Elementos de Direito Constitucional da República Federal da Alemanha. Tradução Luís Afonso Heck. Porto Alegre: Sergio Antonio Fabris, 1998, p. 331. Em adição à "igualdade jurídica material", o autor identifica a "igualdade jurídica formal", que seria a obrigação de se aplicar as leis sem considerações pessoais. Já se falou, neste trabalho, acerca da inocuidade dessa noção.
} 
primeira necessidade. Dessa forma, a referida lei hipotética não estaria de acordo com a igualdade fática, que se relaciona às consequências dos atos do Estado ao impor-lhe um dever positivo - o dever de o Estado, na normatização que estabelecer, levar em consideração as consequências dela oriundas. Assim, pode-se chamar a igualdade fática de "igualdade positiva" ou de "igualdade material". No exemplo da lei tributária, a igualdade fática orientaria a adoção de alíquotas progressivas em função da renda do contribuinte, para que os mais ricos pagassem proporcionalmente mais imposto de renda que os mais pobres.

É certo que, como no exemplo do imposto de renda, a igualdade jurídica muitas vezes vulnera a igualdade fática, que é melhor definida como a “[...] igualdade real e efetiva de todos, perante todos os bens da vida." ${ }^{26}$ Essa definição é a mais ampla possível e abrange as mais diversas teorias sobre a igualdade fática: igualdade de fruição de direitos ${ }^{63}$, igualdade de oportunidades ${ }^{64}$, igualdade de recursos, igualdade de bem-estar ${ }^{65}$, igualdade de consideração para as identidades dos grupos não-hegemônicos no processo social ${ }^{66}$, igualdade de felicidade ${ }^{67}$, etc. Isso é de suma importância por conta do âmbito de proteção amplo dos princípios, como se abordará adiante, que rejeita a exclusão a priori de posições jurídicas do âmbito de proteção da norma.

62 Silva, Sidney Pessoa Madruga da. Discriminação Positiva: Ações Afirmativas na Realidade Brasileira. Brasília: Brasília Jurídica, 2005, p. 41.

${ }^{63}$ Cf. Bastos, Celso Ribeiro. Curso de Direito Constitucional. São Paulo: Celso Bastos Editora, 2002, p. 317 apud Atchabahian, Serge. Princípio da igualdade e ações afirmativas. São Paulo: RCS, 2004, p. 51.

${ }^{64}$ Cf. Gomes, Joaquim B. Barbosa. A recepção do instituto da ação afirmativa pelo Direito Constitucional Brasileiro. Revista de Informação Legislativa, Brasília, a. 38, n. 151, p. 129-151, jul./set. 2001, p. 131. VILAS-BÔAS, Renata Malta. Ações afirmativas e o princípio da igualdade. Rio de Janeiro: América Jurídica, 2003, p. 16. Belmonte, Cláudio Petrini. O sentido e o alcance do princípio da igualdade como meio de controle da constitucionalidade das normas jurídicas na jurisprudência do Tribunal Constitucional de Portugal e do Supremo Tribunal Federal do Brasil. Revista de Informação Legislativa, Brasília, a. 36, n. 144, p. 157-175, out./dez. 1999, p. 163.

${ }^{65}$ Cf. DworkIN, Ronald. A virtude soberana: a teoria e a prática da igualdade. Tradução Jussara Simões. São Paulo: Martins Fontes, 2005, p. 3 et seq.

${ }^{66}$ Informação verbal proferida por ADAMS, Luis Inácio Lucena. Supremo Tribunal Federal. Audiência Pública sobre a Constitucionalidade de Políticas de Ação Afirmativa de Acesso ao Ensino Superior. Brasília: 3 de março de 2010. Disponível em: <http://www.youtube.com/watch?v=lBfsV3tH0T0>. Acesso em: 7 de março de 2010.

${ }^{67}$ Cf. MiLl, John Stuart. Utilitarianism. London: Parker, Son, and Bourn, West Strand, 1863, p. 9 et seq. 
Enquanto a igualdade jurídica é um valor em si mesmo ${ }^{68}$, pressuposto lógicojurídico de todo o sistema constitucional ${ }^{69}$, uma conquista liberal contra os favorecimentos injustificáveis do Ancien Régime e cujo pertencimento ao ordenamento constitucional é inquestionável, a questão do pertencimento da igualdade fática ao ordenamento é mais problemática. Há quem sustente que a igualdade fática só passou a integrar o ordenamento jurídico com a superação do Estado Liberal e o advento do Estado Social, que buscava a paulatina redução das desigualdades sociais mediante a atuação do Estado $^{70}$, pois a concretização do enunciado da igualdade dependeria da concepção de Estado que se $\operatorname{adota}^{71}$.

Esses entendimentos não estão corretos primeiramente porque uma análise histórica mais detida permite concluir que, mesmo no Estado Liberal, nunca houve rejeição ao tratamento jurídico desigual, desde que justificado. A primeira formulação jurídica da igualdade veio com a Declaração de 1789: "Les distinctions sociales ne peuvent être fondées que sur l'utilité commune." (art. $1^{\circ}$, fine, da Declaração dos Direitos do Homem e do Cidadão de 1789). A "utilidade comum" poderia ser levantada ao se conferir tratamentos jurídicos desiguais - distinções sociais -, isto é, poderia haver distinções desde que beneficiassem a sociedade em geral e não em benefício exclusivo dos indivíduos favorecidos. Ora, distinções sociais, nesse contexto, afastam o tratamento jurídico igual de modo que é possível concluir que, mesmo durante a expressão mais radical do Estado Liberal, nunca houve uma concepção formal absoluta e intransigente da igualdade. Desse modo, admitia-se restrições à igualdade jurídica: “[...] desde que uma desigualdade de tratamento jurídico possa ser justificada por um objetivo de interesse público, não haveria quebra do princípio da isonomia."72 Não houve, também, "evolução" para a igualdade

${ }^{68}$ Cf. AleXY, Robert. Teoria dos direitos fundamentais. Tradução Virgílio Afonso da Silva. São Paulo: Malheiros, 2008, p. 420. BoROwSKI, Martin. La estructura de los derechos fundamentales. Tradução Carlos Bernal Pulido. Bogotá: Universidad Externado de Colombia, 2003, p. 191.

${ }^{69}$ Cf. Comparato, Fábio Konder. Igualdade, desigualdades. Revista trimestral de direito público, São Paulo, n. 1,1993, p. 70.

70 Cf. SIlva, Sidney Pessoa Madruga da. Discriminação Positiva: Ações Afirmativas na Realidade Brasileira. Brasília: Brasília Jurídica, 2005, p. 38-39.

${ }^{71}$ Cf. SchOLLER, Heinrich. Die Interpretation des Gleichheitssatzes als Willkürverbot oder also Gebot der Chancengleichheit. Berlin: Duncker \& Humblot, 1969, p. 13 apud ALEXY, Robert. Teoria dos direitos fundamentais. Tradução Virgílio Afonso da Silva. São Paulo: Malheiros, 2008, p. 420.

72 COMPARAto, Fábio Konder. Igualdade, desigualdades. Revista trimestral de direito público, São Paulo, $\mathrm{n}$. 1, 1993, p. 70. 
material $^{73}$ ou a superação da igualdade formal e a adoção da igualdade fática ${ }^{74}$, que deve nortear a atuação do Estado contemporâneo, ou mesmo "mutação constitucional", verdade é que ambas as dimensões da igualdade coexistem e sempre coexistiram, ainda que de forma menos ou mais evidente. Nem se pode "[...] afastar-se de uma visão formalista do princípio da isonomia [... $]^{\prime 76}$, mas se deve tê-la em mente principalmente quando se pretende realizar uma diferenciação legítima com o intuito de proporcionar maior realização ao princípio da igualdade fática.

É possível, mediante a teoria dos princípios, atribuir a igualdade fática ao enunciado da igualdade independentemente da concepção de Estado que se adote. Isso ocorre porque, se for conferida à igualdade fática a estrutura de princípio, e o mesmo for feito em relação à igualdade jurídica, ambas se tornariam razões prima facie à atribuição de tratamentos, permitindo sua coexistência enquanto mandamentos de otimização ${ }^{77}$. $\mathrm{O}$ princípio da igualdade jurídica e o princípio da igualdade fática sempre coexistiram, e a teoria dos princípios pode explicar como podem coexistir, mesmo que frequentemente colidam entre si. Logo, é correta a atribuição ao enunciado da igualdade de ao menos dois princípios correspondentes à igualdade jurídica e à igualdade fática:

El principio general de igualdad se entiende en el sentido de la igualdad jurídica,
cuando la igualdad de trato ordenada constitucionalmente se comprende como
relativa al acto. Esto significa que la igualdad ordena un tratamiento similar en la
ejecución de un mismo acto. [...] Por el contrario, la igualdad fáctica es relativa a
las consecuencias. Este tipo de igualdad apunta a la igualdad en el resultado. Si
existen diferencias naturales o sociales entre las personas cuyas situaciones

${ }^{73}$ Cf. VILAS-BôAS, Renata Malta. Ações afirmativas e o princípio da igualdade. Rio de Janeiro: América Jurídica, 2003, p. 21.

${ }^{74}$ Cf. Montebello, Marianna. As Políticas de Ação Afirmativa sob a Perspectiva do Direito Internacional dos Direitos Humanos. Interesse Público, Porto Alegre, a. 6, n. 29, p. 117-138, jan./fev. 2005, p. 123.

${ }^{75}$ Cf. Kaufmann, Roberta Fragoso Menezes. Ações afirmativas à brasileira: necessidade ou mito? Porto Alegre: Livraria do Advogado, 2007, p. 267.

${ }^{76}$ SARMENTO, Daniel. A igualdade étnico-racial no direito constitucional brasileiro: discriminação "de facto", teoria do impacto desproporcional e ação afirmativa. In: CAMARGO, Marcelo Novelino (Org.). Leituras complementares de direito constitucional: direitos humanos e direitos fundamentais. $3^{\mathrm{a}}$ ed. Salvador: JusPodivm, 2008, p. 217.

77 “[...] é criado um modelo que permite atribuir também o princípio da igualdade fática ao art. $3^{\circ}, \S 1^{\circ}$ [da Lei Fundamental da Alemanha], e, com isso, conceber esse dispositivo constitucional como expressão de um conceito amplo de igualdade, sem que com isso já se decida previamente por alguma determinada concepção de igualdade. A chave teórico-normativa e metodológica para tanto é a teoria dos princípios." ALEXY, Robert. Teoria dos direitos fundamentais. Tradução Virgílio Afonso da Silva. São Paulo: Malheiros, 2008, p. 423. 
deben ser reguladas, para producir una igualdad fáctica es necesario que exista un trato jurídico desigual. ${ }^{78}$

Dessa forma, do enunciado da igualdade, que M. BOROWSKI chama de "princípio geral da igualdade", pode-se atribuir corretamente o princípio da igualdade fática e o princípio da igualdade jurídica. Seguindo a terminologia exposta acima, o princípio geral da igualdade comporta o princípio da igualdade jurídica e o princípio da igualdade fática. Isso pode parecer ilógico, pois parece misturar critérios classificatórios. Mas a questão é puramente terminológica. O que se chama de "princípio geral da igualdade" nada mais é que o enunciado da igualdade previsto tanto na CF quanto na Lei Fundamental da Alemanha. A partir desse enunciado, mediante interpretação, pode-se atribuir corretamente duas normas jurídicas com a estrutura de princípio: o princípio da igualdade fática e o princípio da igualdade jurídica.

Assim, ao afirmar que o princípio da igualdade fática não encontra guarita no art. $5^{\circ}$, caput da $\mathrm{CF}$, mas apenas em normas programáticas diversas ${ }^{79}, \mathrm{R}$. VILAS-BÔAS não está totalmente correta. É verdade que, por integrarem o contexto do enunciado a ser interpretado $^{80}$, as "normas programáticas" a que a autora faz referência orientam a interpretação do enunciado do art. $5^{\circ}$, caput da $\mathrm{CF}$ - o enunciado da igualdade -, mas procurar compreender o princípio da igualdade fática sem referência a esse dispositivo é impossível. Veja-se que as normas extraídas da interpretação dos enunciados que se referem à igualdade, tanto no plano de positivação interno quanto no externo, levam em consideração "[...] a conexão total na qual ela deve ser colocada, [...] de tal modo que contradições com outras normas constitucionais sejam evitadas." ${ }^{81}$ Uma leitura eminentemente "formal" do enunciado da igualdade entraria em contradição com outras

${ }^{78}$ BorowsKi, Martin. La estructura de los derechos fundamentales. Tradução Carlos Bernal Pulido. Bogotá: Universidad Externado de Colombia, 2003, p. 188-189.

${ }^{79}$ Cf. VILAS-BÔAS, Renata Malta. Ações afirmativas e o princípio da igualdade. Rio de Janeiro: América Jurídica, 2003, p. 21.

80 “[...] reconhecer se um enunciado [...] expressa uma norma, deve ser respondido que isso é possível com base em seu contexto. Por 'contexto' devem ser entendidos não somente os outros enunciados que estão em conexão com esse enunciado, mas também seu uso, isto é, as circunstâncias e regras de sua utilização." AlEXY, Robert. Teoria dos direitos fundamentais. Tradução Virgílio Afonso da Silva. São Paulo: Malheiros, 2008, p. 55.

${ }^{81}$ Hesse, Konrad. Elementos de Direito Constitucional da República Federal da Alemanha. Tradução Luís Afonso Heck. Porto Alegre: Sergio Antonio Fabris, 1998, p. 71. Trata-se do "princípio" da unidade da Constituição, que é, segundo K. HESSE, um dos "princípios" da interpretação constitucional. Não se trata, obviamente, de um princípio no sentido utilizado neste trabalho - daí a menção entre aspas -, mas apenas de uma forma de interpretação dos enunciados constitucionais. 
normas constitucionais, como aquela que determina que o Estado construa uma sociedade justa (art. $3^{\circ}$, I da CF), já que, como abordado, situações fáticas desiguais tratadas juridicamente de forma igual podem acarretar "injustiças":

\begin{abstract}
Ocorre que esse entendimento formal do princípio da igualdade, respaldando apenas uma igualdade perante a lei, não é, de per si, garantidor de um tratamento justo e adequado aos cidadãos, tendo em conta as diversas situações vislumbradas no cotidiano das pessoas. Ou seja, se o legislador, ao criar a norma legal, o fizer apenas com base num critério universalista de igualdade dos cidadãos, como se todos estivessem nas mesmas condições culturais, econômicas, saudáveis, etc., mesmo que no próprio preceito legal não faça nenhuma distinção espontânea, efetiva e faticamente poderá estar desrespeitando o princípio da igualdade, pois é sabido que, na prática, as pessoas não se encontram todas nas mesmas situações e condições. ${ }^{82}$
\end{abstract}

Já a leitura "material" do enunciado da igualdade, considerada isoladamente, entraria em contradição, por exemplo, com a proibição de distinções de qualquer natureza (art. 5\% caput da CF). Assim, só faz sentido concluir pela ocorrência concomitante, no ordenamento constitucional, dos princípios da igualdade formal e da igualdade fática, o que apenas aparenta ser um paradoxo, pois, para as inevitáveis colisões entre si, há uma solução racional e intersubjetivamente controlável - a máxima da proporcionalidade, a ser analisada com profundidade adiante.

Uma crítica que se pode levantar contra a atribuição do princípio da igualdade fática diz respeito às inúmeras teorias sobre a igualdade de fato. Certamente não há um critério para se determinar qual é a igualdade fática que a CF busca: pode ser a igualdade de felicidade, a igualdade de bem-estar, a igualdade de recursos, a igualdade de fruição de direitos, etc. Mas isso não é um problema. Ao se definir a igualdade fática como um princípio, por conta âmbito de proteção amplo que é característico dessa espécie de norma, automaticamente se incluem todas as teorias sobre a igualdade fática no âmbito de proteção daquele princípio. Explica-se melhor.

As normas de direito fundamental com o caráter de princípio possuem um suporte de fato amplo e, por consequência, um âmbito de proteção também amplo. O suporte de fato, embora seja um conceito pouco utilizado no campo do Direito Constitucional, é de grande relevância no que diz respeito a direitos fundamentais. Esse conceito foi cunhado

\footnotetext{
${ }^{82}$ Belmonte, Cláudio Petrini. O sentido e o alcance do princípio da igualdade como meio de controle da constitucionalidade das normas jurídicas na jurisprudência do Tribunal Constitucional de Portugal e do Supremo Tribunal Federal do Brasil. Revista de Informação Legislativa, Brasília, a. 36, n. 144, p. 157-175, out./dez. 1999, p. 160.
} 
no campo do Direito Civil e equivale à "hipótese de incidência" do Direito Tributário ${ }^{83}$. Constituem o suporte de fato "[...] fatos ou atos do mundo que são descritos por determinada norma e para cuja realização ou ocorrência de prevê determinada conseqüência jurídica: preenchido o suporte fático, ativa-se a conseqüência jurídica." ${ }^{84}$

O suporte de fato, segundo R. AleXY e M. BOROwsKI, no caso dos direitos fundamentais que têm a estrutura de princípio, é composto pelo âmbito de proteção e pela intervenção. A esses dois componentes V. SILVA adiciona a ausência de fundamentação constitucional, formulando o suporte fático da seguinte maneira: se algo é garantido pelo âmbito de proteção de um direito fundamental (APx) e se há uma intervenção nesse âmbito de proteção (IEx) não fundamentada constitucionalmente (não-FCx), então deverá ser ativada a consequência jurídica prevista (CJx), ou seja, “[...] se APx e não-FC(IEx), então $C J x[\ldots]^{» 85}$. A consequência jurídica, no caso dos direitos fundamentais, geralmente é a cessação da intervenção e o retorno ao status quo ante, no caso dos direitos de defesa, ou uma prestação, nos casos de direitos a prestações. Em última análise, essa formulação visa justamente a coibir o sacrifício desnecessário ou injustificado de direitos fundamentais.

Em outras palavras, convém, novamente, dar um exemplo. Tocar trompete está dentro do âmbito de proteção da liberdade artística (art. $5^{\circ}$, IX da CF), pois milita em favor de sua proteção ${ }^{86}$. Suponha-se que uma autoridade competente proíba um músico de executar suas composições para trompete nas casas noturnas porque não gosta do trabalho do artista. Todos os elementos do suporte de fato, nesse caso, foram configurados: se tocar trompete está no âmbito de proteção da liberdade artística e não houve uma fundamentação constitucional para a intervenção nesse direito, então a intervenção é uma violação ao direito e deve cessar. Outro seria o caso de um bêbado frustrado que pretenda fazer

\footnotetext{
${ }^{83}$ Cf. SILVA, Virgílio Afonso da. Direitos fundamentais: conteúdo essencial, restrições e eficácia. $2^{\mathrm{a}}$ ed. São Paulo: Malheiros, 2010, p. 66.

84 SILVA, Virgílio Afonso da. Direitos fundamentais: conteúdo essencial, restrições e eficácia. $2^{\mathrm{a}}$ ed. São Paulo: Malheiros, 2010, p. 67-68.

${ }^{85}$ Silva, Virgílio Afonso da. Direitos fundamentais: conteúdo essencial, restrições e eficácia. $2^{\mathrm{a}}$ ed. São Paulo: Malheiros, 2010, p. 67-68.

86 "Uma teoria ampla do suporte fático é uma teoria que inclui no âmbito de proteção de cada princípio de direito fundamental tudo aquilo que milite em favor de sua proteção. [...] No campo semântico dos conceitos de suporte fático devem ser adotadas interpretações amplas."AlEXY, Robert. Teoria dos direitos fundamentais. Tradução Virgílio Afonso da Silva. São Paulo: Malheiros, 2008, p. 322.
} 
improvisações de trompete na rua, de madrugada, no exercício de sua liberdade artística ${ }^{87}$. Nesse caso, a autoridade que o impede não encontraria problemas em fundamentar constitucionalmente sua intervenção na proteção ao meio-ambiente urbano equilibrado ${ }^{88}$, por exemplo. Assim, embora o ato de tocar trompete se encontre no âmbito de proteção da norma, não se configurou o suporte de fato porque a intervenção é legítima - é tão somente uma restrição - e, portanto, não se ativa a consequência jurídica ${ }^{89}$.

Dessa forma, o âmbito de proteção de um direito fundamental com a estrutura de princípio é um dos componentes de seu suporte de fato - e é seu componente mais importante. $\mathrm{O}$ âmbito de proteção diz respeito "[...] àquilo que a norma de direito fundamental garante prima facie, ou seja, sem levar em consideração as possíveis restrições." ${ }^{90}$ Em outras palavras:

[...] o que é protegido prima facie por esse direito [fundamental]? Essa pergunta deve ser respondida da seguinte forma: toda ação, estado ou posição jurídica que possua alguma característica que, isoladamente considerada, faça parte do 'âmbito temático' de um determinado direito fundamental, deve ser considerada como abrangida por seu âmbito de proteção, independentemente da consideração de outras variáveis." ${ }^{.1}$

Os princípios trazem obrigações, proibições ou permissões prima facie, ou seja, não definitivas. $\mathrm{O}$ ato de matar alguém - o que é, de certa maneira, contra-intuitivo - é um ato prima facie protegido pelo direito à liberdade, pois, ao se situar no âmbito temático da norma, se situa dentro do seu âmbito de proteção, que é amplíssimo. Contudo, não é um direito definitivo porque, nesse aspecto, o direito à liberdade será legitimamente

87 Exemplo trazido por ERBEL, Günter. Inhalt und Auswirkungen der verfassungsrechtlichen Kunstfreiheitsgarantie. Berlin: Springer, 1996, p. 95 apud SILVA, Virgílio Afonso da. Direitos fundamentais: conteúdo essencial, restrições e eficácia. 2a ed. São Paulo: Malheiros, 2010, p. 98.

${ }^{88}$ Certamente, nesse exemplo, a autoridade orientará sua atuação com base na legalidade de tal ato, como no art. 42, III do Decreto-Lei $n^{\circ}$ 3.688/41 (Contravenções Penais). Isso, contudo, ocorre porque, no ordenamento brasileiro, já houve um sopesamento, por parte do legislador, cujo resultado, nessa hipótese, concluiu pela prevalência do meio-ambiente urbano equilibrado sobre a liberdade artística. Para melhor se compreender o exemplo, suponha-se que não haja qualquer regulamentação infraconstitucional nesse sentido.

89 “'Se houver fundamentação constitucional para a intervenção, estar-se-á diante não de uma violação, mas de uma restrição constitucional ao direito fundamental, o que impede a ativação da conseqüência jurídica". SILVA, Virgílio Afonso da. O conteúdo essencial dos direitos fundamentais e a eficácia das normas constitucionais. Revista de Direito do Estado, Rio de Janeiro, a. 1, n. 4, p. 23-51, out./dez. 2006, p. 31.

90 AleXy, Robert. Teoria dos direitos fundamentais. Tradução Virgílio Afonso da Silva. São Paulo: Malheiros, 2008, p. 302.

91 Silva, Virgílio Afonso da. O conteúdo essencial dos direitos fundamentais e a eficácia das normas constitucionais. Revista de Direito do Estado, Rio de Janeiro, a. 1, n. 4, p. 23-51, out./dez. 2006, p. 34-35. 
restringido (por uma norma penal, por exemplo) tendo-se em vista o direito à vida dos demais indivíduos.

Tudo isso significa que não é possível excluir a priori uma situação ou posição jurídica do âmbito de proteção de um princípio como se pode fazer com uma regra. Com efeito, as regras se encontram, por excelência, na esfera do suporte fático restrito, e não são limitáveis como são os princípios ${ }^{92}$. O direito definitivo só é atribuído após a aplicação da máxima da proporcionalidade e, se o caso, do sopesamento ${ }^{93}$.

À primeira vista pode parecer que a noção de âmbito de proteção amplo e a de direitos prima facie implicam insegurança na proteção dos diretos fundamentais: se os direitos fundamentais - em sua maior parte princípios - são, por definição, limitáveis, então a CF confere direitos que, na verdade, "não valem"? Não seria mais seguro conferir a esses direitos um conteúdo essencial, intangível e ilimitável? Na verdade, ocorre bem o contrário. Conferir um conteúdo essencial a um princípio implica excluir a priori - ou seja, abstratamente, sem considerar os casos concretos - do seu âmbito de proteção determinadas condutas ou situações seguindo uma teoria interna, na qual só existe um objeto: o direito com seu conteúdo. O agente que executasse a conduta ou estivesse na posição jurídica excluídas, portanto, agiria "sem direito" ou "não teria direito a". Já se pode perceber como essa postura pode dar ensejo a arbitrariedades ou a exclusões intuitivas baseadas nas concepções pessoais do agente ou em meros juízos de conveniência e oportunidade, sem haver espaço para se falar em restrições a direitos ${ }^{94}$. Na teoria externa, por sua vez, há dois objetos: o direito com a estrutura de princípio e suas restrições. Por ser uma norma jurídica, o princípio "vale" e, por ser um mandamento de otimização, "vale o máximo possível". Os princípios tanto devem "valer" que devem ser realizados na maior medida do possível, não admitindo exclusões a priori de seu âmbito de proteção e só admitindo intervenções se devidamente fundamentadas em âmbito constitucional. O agente que executasse a conduta ou estivesse na posição jurídica agiria, em tese, "com direito" ou "teria direito a", embora não definitivo ou restringido. Desse modo, a carga argumentativa de quem pretende estabelecer uma restrição a um princípio é considerável: em vez de se

92 Cf. Borowski, Martin. La estructura de los derechos fundamentales. Tradução Carlos Bernal Pulido. Bogotá: Universidad Externado de Colombia, 2003, p. 76-77.

93 Cf. Silva, Virgílio Afonso da. O conteúdo essencial dos direitos fundamentais e a eficácia das normas constitucionais. Revista de Direito do Estado, Rio de Janeiro, a. 1, n. 4, p. 23-51, out./dez. 2006, p. 40.

94 Cf. Silva, Virgílio Afonso da. Direitos fundamentais: conteúdo essencial, restrições e eficácia. $2^{\mathrm{a}}$ ed. São Paulo: Malheiros, 2010, p. 80-81. 
afirmar que a conduta/posição jurídica $x$, embora se situe no "âmbito temático" do princípio $P_{l}$, não é protegida pelo princípio $P_{l}$, deve-se afirmar que a conduta/posição jurídica $x$ é, prima facie, protegida pelo princípio $P_{l}$, mas, no caso concreto, não é definitivamente protegida pelas razões $r_{1} \ldots r_{n}$.

A exposição sobre o âmbito de proteção amplo dos princípios tem relevância na análise do princípio da igualdade jurídica, mas encontra sua maior importância na análise do princípio da igualdade fática. No primeiro caso, significa que todo e qualquer tratamento jurídico igual se encontra no âmbito de proteção do princípio da igualdade jurídica. Assim, afirmar que todos os contribuintes têm o direito prima facie a que o Estado estabeleça alíquotas fixas para o imposto de renda não é falso, assim como não o é afirmar que todos têm o direito prima facie de que sua raça ou sexo não sejam usados como critérios de diferenciação. Contudo, podem ou não ser direitos definitivos, pois o princípio pode restringido: “[...] no sólo los derechos de libertad, sino además los derechos de igualdad y los derechos constitucionales prestacionales, constituyen derechos fundamentales limitables." 95

No segundo caso, significa que toda e qualquer situação de igualdade fática está no âmbito de proteção do princípio da igualdade fática. Não é falso afirmar que o Estado tem o dever prima facie de determinar que todos usem a mesma roupa, que recebam o mesmo salário ou que tenham a mesma cor de olhos, assim como não é falso afirmar que o Estado tem o dever prima facie de assegurar as mesmas oportunidades a todos. Novamente, esses deveres podem ou não ser definitivos a depender das circunstâncias fáticas e jurídicas existentes.

\subsection{Colisões entre princípios}

$\mathrm{Na}$ medida em que a realização da igualdade fática muitas vezes entra em colisão com a igualdade jurídica e na medida em que outros princípios constitucionais podem também entrar em colisão tanto com o princípio da igualdade fática quanto com o da

\footnotetext{
95 BoROwSKI, Martin. La restricción de los derechos fundamentales. Tradução Rodolfo Arango. Revista Española de Derecho Constitucional, Madrid, a. 20, n. 59, p. 29-56, mayo/agosto 2000, p. 30.
} 
igualdade jurídica, torna-se fundamental analisar as possíveis colisões que podem surgir entre os princípios relacionados à igualdade.

De início, é conveniente afirmar que, por conta do âmbito de proteção amplo dos princípios, são inúmeras as colisões entre si. Poder-se-ia inclusive alegar que, se adotada a noção de âmbito de proteção amplo, o sistema jurídico sequer poderia ser minimamente operacional, uma vez que todas as questões envolveriam colisões entre princípios constitucionais, ao contrário do que ocorreria com a adoção do âmbito de proteção restrito (que não admite ou admite poucas colisões). Ademais, não se definir a priori o que "efetivamente vale", como fazem as regras, dá ensejo a grande insegurança jurídica imprevisibilidade -, problemas de coordenação e altos custos na administração da justiça ${ }^{96}$. Conquanto os problemas indicados façam todo o sentido, afirmar que a adoção do âmbito de proteção amplo para os princípios prejudica ou impossibilita a operacionalização do sistema jurídico não é verdade.

Primeiramente, deve-se ter em mente que se trabalha com um sistema misto de regras e princípios ${ }^{97}$. De fato, principalmente em um sistema jurídico com um catálogo de normas tão extenso como o brasileiro e tendo-se em vista o caráter notoriamente "regulatório" da $\mathrm{CF}^{98}$, a grande maioria das colisões entre princípios já foi resolvida, mediante regras, pelo próprio constituinte, pelo legislador ${ }^{99}$ infraconstitucional ou pela jurisprudência:

[...] pode-se afirmar: como resultado de todo sopesamento que seja correto do ponto de vista dos direitos fundamentais pode ser formulada uma norma de

96 Cf. ÁvilA, Humberto. "Neoconstitucionalismo": entre a "ciência do direito" e o "direito da ciência". Revista Eletrônica de Direito do Estado, Salvador, n. 17, jan./mar. 2009. Disponível em: $<$ http://www.direitodoestado.com.br/rede/edicao/17>. Acesso em: 28 de outubro de 2009, p. 4.

97 “[...] esse modelo [puro de regras] é insuficiente também para as outras formas de regulação encontradas na Constituição alemã. O modelo puro de princípios foi rejeitado porque ele não leva a sério as regulações adotadas pela Constituição." ALEXY, Robert. Teoria dos direitos fundamentais. Tradução Virgílio Afonso da Silva. São Paulo: Malheiros, 2008, p. 135.

98 Cf. ÁvilA, Humberto. "Neoconstitucionalismo": entre a "ciência do direito" e o "direito da ciência". Revista Eletrônica de Direito do Estado, Salvador, n. 17, jan./mar. 2009. Disponível em: $<$ http://www.direitodoestado.com.br/rede/edicao/17>. Acesso em: 28 de outubro de 2009, p. 7.

${ }^{99}$ Neste ponto, vale a observação de V. SILVA: “'Legislador', aqui, é termo empregado em sentido amplo, e envolve qualquer forma de produção normativa - incluindo, por exemplo, medidas provisórias e decretos." SILVA, Virgilio Afonso da. Direitos fundamentais: conteúdo essencial, restrições e eficácia. $2^{a}$ ed. São Paulo: Malheiros, 2010, p. 143. 
direito fundamental atribuída, que tem a estrutura de uma regra e à qual o caso pode ser subsumido. ${ }^{100}$

R. ALEXY reconstrói logicamente uma colisão entre princípios da seguinte maneira: suponha-se que o princípio $P_{1}$ colida com o princípio $P_{2}$, por exemplo, porque algo é obrigatório para um, mas é proibido para o outro. Essa colisão será resolvida mediante o estabelecimento de uma relação de precedência condicionada $\mathbf{P}$ para o caso concreto, ou seja, um princípio terá precedência sobre outro nas circunstâncias $C$. Desse modo, só haveria duas soluções possíveis para a colisão: $\left(P_{1} \mathbf{P} P_{2}\right) C$ ou $\left(P_{2} \mathbf{P} P_{1}\right) C^{101}$, ou seja, ou $P_{1}$ prevalece sobre $P_{2}$ nas circunstâncias do caso concreto ou $P_{2}$ prevalece sobre $P_{1}$ nas circunstâncias do caso concreto. Suponha-se que se tenha decidido, nesse caso, que $P_{1}$ deva prevalecer: $\left(P_{1} \mathbf{P} P_{2}\right) C$. Desse enunciado de precedência resulta uma regra segundo a qual, diante das condições $C$, deve-se operar a consequência jurídica $R$ do princípio $P_{1}$. C, portanto, é o suporte de fato de uma regra que traz, como consequência jurídica, $R$. Isso é o que o autor chama de "lei de colisão"102.

Ilustra-se a construção acima com um exemplo. Retoma-se o caso do bêbado frustrado que pretende fazer improvisações de trompete na rua, de madrugada $(C)$, no exercício de seu direito à liberdade artística $\left(P_{2}\right)$. A autoridade policial, baseando-se na proteção ao meio ambiente urbano equilibrado $\left(P_{1}\right)$, o impede $(R)$. O bêbado frustrado ajuiza um mandado de segurança alegando que a autoridade cerceou seu direito à liberdade artística, mas a ação é julgada improcedente, decidindo-se que, no caso, a proteção ao meio ambiente urbano equilibrado prevalece sobre a liberdade artística $\left(\left(P_{1} \mathbf{P} P_{2}\right) C\right)$. Nesse caso, a solução da colisão entre os princípios é a seguinte regra: "é proibido tocar trompete na rua, de madrugada, sob pena de ser coagido a cessar a conduta" $(C \rightarrow R)$.

É curioso notar que, no Brasil, o exemplo acima dificilmente ocorreria, pois a colisão entre os princípios da liberdade artística e da proteção do meio ambiente urbano equilibrado exposta já foi resolvida pelo legislador infraconstitucional na edição do art. 42,

100 AleXY, Robert. Teoria dos direitos fundamentais. Tradução Virgílio Afonso da Silva. São Paulo: Malheiros, 2008, p. 102. “[...] Alexy es claro al sostener que la ley de colisión que determina la prevalencia de un principio sobre el otro es una regla." MANIACI, Giorgio. Algunas notas sobre coherencia y balance en la teoría de Robert Alexy. Tradução José Juan Moreso. Isonomía, México, n. 20, p. 137-177, abr. 2004, p. 143.

101 Cf. AleXY, Robert. Teoria dos direitos fundamentais. Tradução Virgílio Afonso da Silva. São Paulo: Malheiros, 2008, p. 97.

102 Cf. AleXY, Robert. Teoria dos direitos fundamentais. Tradução Virgílio Afonso da Silva. São Paulo: Malheiros, 2008, p. 99. 
III do Decreto-Lei $n^{0} 3.688 / 41$ (Contravenções Penais) ${ }^{103}$. O bêbado frustrado não teria "direito líquido e certo" ( = direito definitivo) a tocar trompete na rua, de madrugada, mas apenas direito prima facie. O legislador, dentro de sua competência, determinou uma relação condicionada de precedência. Isso significa que, na grande maioria dos casos em que há colisões entre princípios, a solução já foi estabelecida tanto pelo próprio constituinte quanto pelo legislador infraconstitucional ou pelas decisões reiteradas dos tribunais (jurisprudência). São relativamente raras as colisões entre princípios que deverão ser solucionadas pelo Poder Judiciário. Não persistem as críticas quanto à insegurança jurídica, aos problemas de coordenação e aos altos custos na administração da justiça, até porque o sistema jurídico é constituído em sua maior parte por regras. Usando a terminologia de J. CANOTILHO, a "concretização" é mais legislativa que judicial ${ }^{104}$. Convém ainda mencionar que a preocupação com o fato de que as relações condicionadas de precedência só podem ser estabelecidas no caso concreto advém do uso comum do termo "caso concreto", que seria o caso levado à apreciação do Poder Judiciário. Desse modo, poder-se-ia inferir que as relações condicionadas de precedência só poderiam ser estabelecidas pelo Poder Judiciário, que é o órgão que aprecia os "casos concretos", entulhando os tribunais e provocando um caos operacional da Justiça. No entanto, não é esse o caso:

A expressão 'caso concreto' pode significar duas coisas distintas: (1) 'caso
concreto' pode significar, na forma como pode ser compreendida também em
sua acepção não-técnica, a decisão de um caso específico por parte do Judiciário
(o exemplo mais usual é a colisão entre a liberdade de imprensa e o direito à
privacidade, honra ou imagem); (2) mas 'caso concreto' pode também significar
algo menos concreto, ou, pelo menos, mais distante daquilo que usualmente se
costuma entender por isso, já que aponta, nessa segunda acepção, a uma decisão
do legislador acerca da colisão entre direitos fundamentais. Uma tal decisão
legislativa, se por um lado é mais abstrata do que uma decisão judicial, não deixa
de ter também a sua dimensão concreta, já que o legislador não se preocupa,
nesses casos, com importância geral e abstrata de dois direitos fundamentais,
mas de sua importância relativa, em uma situação hipotética. Exemplo dessa
acepção seria, entre outros, a atividade legislativa que cria o tipo penal de calúnia
(CP, art. 138). O 'concreto', nesse ponto, não é um caso específico que acontece
na realidade, mas a situação hipotética, descrita e 'resolvida' pelo legislador em

103 “Art. 42. Perturbar alguém o trabalho ou o sossego alheios:

[...]

III - abusando de instrumentos sonoros ou sinais acústicos;

$[\ldots]$

Pena - prisão simples, de quinze dias a três meses, ou multa [...]"

${ }^{104}$ Cf. CANotilho, José Joaquim Gomes. Direito Constitucional e Teoria da Constituição. $7^{\mathrm{a}}$ ed. Coimbra: Almedina, 2003, p. 1183. 
um certo sentido - a favor da honra, em detrimento da liberdade de expressão -, que pressupõe uma decisão acerca de um direito e de suas restrições. ${ }^{105}$

A solução de uma colisão entre princípios mediante uma regra significa, em última análise, que a restrição ao princípio afastado se dá formalmente por uma regra, mas materialmente se dá pelo princípio que sustenta a regra porque, em todo caso em que há uma restrição a um princípio por uma regra infraconstitucional ou por uma decisão judicial, estas devem estar sustentadas por princípios constitucionais ${ }^{106}$.

Ademais, as relações condicionadas de precedência, estabelecidas por regras, são, por sua essência, derrotáveis. As regras têm um caráter definitivo, isto é, são razões definitivas para algo, mas podem perder seu caráter definitivo e se converter em razões prima facie porque sempre é possível falsear as assunções teóricas e empíricas que fundamentaram determinada relação condicionada de precedência ${ }^{107}$. Afinal, nem todas as propriedades das circunstâncias do caso concreto que no futuro serão consideradas relevantes são ou podem ser identificáveis à época do sopesamento. Pelo exposto, se forem levadas em conta eventuais descobertas de novas propriedades das circunstâncias já levadas ao sopesamento, é possível, inclusive, que ocorra a inversão da relação de precedência condicionada:

“[...] si Carlos en el tiempo $\mathrm{t}^{0}$ ha considerado justa, en condiciones epistémicas ideales o óptimas, una acción $\mathrm{y}$, debe considerar también justa en el tiempo $\mathrm{t}^{1}$ cualquier otra acción que tenga las mismas propiedades que se consideraron relevantes en $\mathrm{t}^{0}$, a menos que en $\mathrm{t}^{1}$ Carlos identifique una nueva propiedad relevante, en virtud de la falsación en $\mathrm{t}^{1}$ de algunas asunciones teóricas $\mathrm{y}$ empíricas compartidas por la comunidad de discurso en el tiempo $\mathrm{t}^{0} ., 108$

É justamente em virtude dessa possibilidade de se derrotar uma regra que estabelece uma relação condicionada de precedência que não é estranha aos operadores do direito a queda em desuso de certas regras (desuetudo derogatoria), como ocorreu, no

\footnotetext{
105 SILVA, Virgílio Afonso da. O conteúdo essencial dos direitos fundamentais e a eficácia das normas constitucionais. Revista de Direito do Estado, Rio de Janeiro, a. 1, n. 4, p. 23-51, out./dez. 2006, p. 40.

${ }^{106}$ BOROWSKI, Martin. La estructura de los derechos fundamentales. Tradução Carlos Bernal Pulido. Bogotá: Universidad Externado de Colombia, 2003, p. 41.

${ }^{107}$ Cf. MANiACI, Giorgio. Algunas notas sobre coherencia y balance en la teoría de Robert Alexy. Tradução José Juan Moreso. Isonomía, México, n. 20, p. 137-177, abr. 2004, p. 139-143.

${ }^{108}$ MANIACI, Giorgio. Algunas notas sobre coherencia y balance en la teoría de Robert Alexy. Tradução José Juan Moreso. Isonomía, México, n. 20, p. 137-177, abr. 2004, p. 168.
} 
Brasil, até passado próximo, com o crime de adultério ${ }^{109}$. Contudo, é de se notar que a carga argumentativa de quem pretende ver uma regra derrotada é consideravelmente maior, pois, além de derrotar o princípio que sustenta materialmente a regra, deve derrotar o princípio formal segundo o qual as regras estabelecidas pelo legislador são definitivas e devem ser obedecidas ${ }^{110}$.

O próprio constituinte, ao estabelecer regras - inclusive regras que protegem direitos fundamentais -, também já estabeleceu muitas relações de precedência condicionadas. Apenas para citar um exemplo, o art. 37, VIII da CF determina que o Estado edite lei que reserve vagas de cargos ou empregos públicos para as pessoas portadoras de deficiência. Trata-se de uma regra: o Estado está obrigado a editar lei que reserve percentual das vagas em cargos ou empregos públicos; ou o faz e cumpre a norma, ou não o faz e a descumpre, não havendo espaço para sopesamento. Essa regra nada mais é que a solução de uma colisão entre o princípio da igualdade fática $\left(P_{l}\right)$ que prevaleceu $(\mathbf{P})$ sobre o princípio da igualdade jurídica $\left(P_{2}\right)$ na circunstância que envolve o acesso de pessoas portadoras de deficiência a cargos ou empregos públicos $(C)$, ensejando uma consequência jurídica $(R)$, que é a consequência jurídica do princípio prevalente - no caso, uma prestação normativa do Estado. A solução pode ser perfeitamente reconstruída pela fórmula $\left(P_{1} \mathbf{P} P_{2}\right) C$.

Apesar da relevância do exemplo do acesso de pessoas portadoras de deficiência ao funcionalismo público, trata-se de uma exceção, pois, no caso de colisão entre o princípio da igualdade fática e o princípio da igualdade jurídica, há relativamente poucos casos concretos de colisão cujas soluções já estejam estabelecidas na própria $\mathrm{CF}$, na legislação infraconstitucional ou na jurisprudência. Isso significa que, no Brasil, a igualdade é um campo fértil para colisões entre esses princípios, que R. ALEXY chama de "paradoxo da igualdade": "[s]e se estende o princípio da igualdade tanto à igualdade jurídica como à

\footnotetext{
${ }^{109}$ Até o ano de 2005, o art. 240 do Código Penal tipificava como crime o adultério. A Lei $\mathrm{n}^{\circ} 11.106 / 95$ veio a revogar tal artigo, que, no entanto, não vinha sendo aplicado há muito tempo. O que importa notar é que o estabelecimento desse tipo penal, em 1940, significou resolver a colisão entre o princípio da proteção à família e o princípio da liberdade sexual, no caso de relações sexuais extraconjugais, a favor do primeiro. Em que pesem as circunstâncias permanecerem as mesmas, novas propriedades dessas circunstâncias passaram a ser relevadas pela comunidade do discurso, em especial após a revolução sexual dos anos 60 . Em outras palavras, essa regra foi "derrotada".

${ }^{110}$ Cf. AleXY, Robert. Teoria dos direitos fundamentais. Tradução Virgílio Afonso da Silva. São Paulo: Malheiros, 2008, p. 90-91. A possibilidade de colisões entre uma regra e um principio é, segundo V. SILVA, “[...] talvez o ponto mais complexo e menos explorado da teoria dos princípios." Não é o caso de se adentrar, aqui, nessa discussão, motivo pelo qual se remete a: SILVA, Virgílio Afonso da. Direitos fundamentais: conteúdo essencial, restrições e eficácia. $2^{\text {a }}$ ed. São Paulo: Malheiros, 2010, p. 51-56.
} 
fática, então se encontra irrecusavelmente esse paradoxo da igualdade. O paradoxo da igualdade é uma colisão que se apresenta tanto mais fortemente quanto mais é realizado em estado social."111 O "paradoxo", contudo, é apenas aparente:

\begin{abstract}
Sem dúvida, não há nada de paradoxal na idéia de que o direito de um indivíduo à igual proteção [da lei] pode às vezes entrar em conflito com uma política social desejável sob outros aspectos, inclusive aquela que tem por objetivo tornar a sociedade mais igual em termos gerais. ${ }^{112}$
\end{abstract}

O "paradoxo da igualdade" significa apenas que os princípios da igualdade fática e da igualdade jurídica podem colidir entre si, especialmente porque "[...] igualdad jurídica y libertad general de adquisición [...] en modo alguno eliminan la desigualdad natural y económica de las personas, sino que permiten que se desarrollen por completo." "113 A colisão é, entrementes, frequente, mas não é necessária. Veja-se que, por exemplo, com a abolição dos privilégios estamentais do Ancien Régime, houve um revigoramento da igualdade fática sob certos aspectos ${ }^{114}$ - como foi o caso do acesso a cargos públicos. Também é possível que ambos os princípios não colidam entre si.

Nas colisões entre os princípios da igualdade fática e da igualdade jurídica, há uma particularidade que deve ser ressaltada: a relação entre esses princípios é assimétrica. Isso significa que o tratamento jurídico igual é ordenado caso não haja razões suficientes para o tratamento jurídico desigual ${ }^{115}$, o que se resume na célebre frase de I. BERLIN: “[t]he assumption is that equality needs no reasons, only inequality does so [... $]^{, 116}$.

O tratamento jurídico igual se autojustifica. Segundo I. BERLIN, “[...] no reason need be given for not withholding them i.e., for an equal distribution of benefits for that is 'natural' - self-evidently right and just, and needs no justification, since it

\footnotetext{
${ }^{111}$ AleXY, Robert. Constitucionalismo Discursivo. $2^{\mathrm{a}}$ ed. Tradução Luís Afonso Heck. Porto Alegre: Livraria do Advogado, 2008, p. 59.

112 DwORKIN, Ronald. Levando os direitos a sério. Tradução Nelson Boeira. São Paulo: Martins Fontes, 2002, p. 349.

${ }^{113}$ BöCKENFÖRDE, Ernst-Wolfgang. Escritos sobre Derechos Fundamentales. Tradução Juan Luis Requejo Pagés e Ignacio Villaverde Menéndez. Baden-Baden: Nomos, 1993, p. 86.

${ }^{114}$ Cf. ALEXY, Robert. Teoria dos direitos fundamentais. Tradução Virgílio Afonso da Silva. São Paulo: Malheiros, 2008, p. 417.

115 Cf. Borowski, Martin. La estructura de los derechos fundamentales. Tradução Carlos Bernal Pulido. Bogotá: Universidad Externado de Colombia, 2003, p. 191.

${ }^{116}$ Berlin, Isaiah. Equality. Proceedings of the Aristotelian Society, London, new series v. 56, p. 321-326, 1955/1956, p. 305.
} 
is in some sense conceived as being self-justified." $" 117 \mathrm{O}$ relevante para explicar essa autojustificação é definitivamente a segurança na sua aplicação, pois quem decide sobre o estabelecimento de um tratamento jurídico desigual só tem uma visão incompleta sobre a realização da igualdade fática e não tem controle total sobre o processo dessa realização. Para ilustrar essa ideia, R. AlEXY cita o exemplo do pai que, no desejo de presentear ambos os filhos, dá a cada um deles uma bola ${ }^{118}$. Nesse caso, o pai cumpriu exemplarmente o princípio da igualdade fática - a igualdade relacionada aos atos -, pois é extremamente difícil saber, por exemplo, se algum de seus filhos não gosta de esportes e não ficou feliz, hipótese em que se configuraria desigualdade de felicidade (desigualdade relacionada às consequências do ato). Para ir além do exemplo citado, suponha-se que um dos filhos seja, por exemplo, paraplégico: nesse caso, a consequência desigual do ato é bem mais evidente, podendo inclusive afastar o igual tratamento jurídico.

Outro exemplo, desta vez trazido por I. BERLIN, é aquele da pessoa que reparte um bolo em dez fatias iguais e distribui uma fatia para cada um dos dez comensais ${ }^{119}$. Certamente a pessoa não teria que justificar seu procedimento, muito embora um dos comensais tivesse mais fome que outros que acabaram de tomar uma refeição, o que ensejaria desigualdade de saciedade. O partidor do bolo teria que justificar seus atos apenas se desse uma fatia maior ou menor que as demais para algum ou alguns dos comensais, ou se não desse nenhuma fatia para algum deles.

É possível que se cogite ser a relação assimétrica entre o princípio da igualdade jurídica e o princípio da igualdade fática uma espécie de relação absoluta de precedência, ou seja, na colisão entre ambos os princípios, o primeiro prevaleceria por ter maior peso absoluto. A solução da colisão teria, assim, a estrutura $P_{1} \mathbf{P} P_{2}$, e não a estrutura $\left(P_{1} \mathbf{P} P_{2}\right)$ $C$. Isso, contudo, não ocorre porque é inegável que possa haver casos em que o princípio da igualdade fática, isolada ou principalmente, prevaleça sobre o princípio da igualdade jurídica, a depender das circunstâncias do caso, como no exemplo do acesso das pessoas portadoras de deficiência a cargos ou empregos públicos. A relação assimétrica é, na

117 Cf. BerLin, Isaiah. Equality. Proceedings of the Aristotelian Society, London, new series v. 56, p. 321$326,1955 / 1956$, p. 304.

${ }^{118}$ Cf. Alexy, Robert. Teoria dos direitos fundamentais. Tradução Virgílio Afonso da Silva. São Paulo: Malheiros, 2008, p. 419.

${ }^{119}$ Cf. Berlin, Isaiah. Equality. Proceedings of the Aristotelian Society, London, new series v. 56, p. 321$326,1955 / 1956$, p. 305. 
verdade, apenas uma questão de distribuição de ônus argumentativo ${ }^{120}$ advinda da própria racionalidade do discurso ${ }^{121}$.

Ainda que o tratamento jurídico igual se autojustifique, o principio da igualdade jurídica, por ser princípio, é limitável e “[...] sufre una intervención, cuando el Estado introduce una diferenciación." ${ }^{122}$ Dessa forma, no âmbito do princípio da igualdade jurídica, a "discriminação" seria a violação - a intervenção não justificada - e a "distinção" ou a "diferenciação integradora", a restrição - a intervenção justificada. A terminologia proposta é mais conveniente para a base metodológica do trabalho, pois são admitidas restrições a princípios, inclusive princípios de direitos fundamentais, afinal, “[...] quando o constituinte [...] relativizou o exercício de direitos fundamentais, sob diversas condições, possibilitou a diferenciação integradora." ${ }^{\text {"123 }}$ Ademais, como será avaliado oportunamente, a palavra "discriminação", por ter uma carga semântica negativa, pode sugerir subliminarmente a impropriedade das "discriminações positivas" 124 . Não obstante, há muitas formas terminológicas para se expressar essa diferença, como o próprio uso das expressões "discriminação positiva" ou "discriminação afirmativa" em oposição à “discriminação" pura e simples.

${ }^{120}$ Cf. Alexy, Robert. Teoria da argumentação jurídica. Tradução Zilda Hutchinson Schild Silva. São Paulo: Landy, 2001, p. 259.

${ }^{121}$ Cf. AleXY, Robert. Teoria da argumentação jurídica. Tradução Zilda Hutchinson Schild Silva. São Paulo: Landy, 2001, p. 193. No mesmo sentido, Rawls, John. Collected Papers. Cambridge: Harvard University Press, 1999, p. 49.

${ }^{122}$ Borowski, Martin. La estructura de los derechos fundamentales. Tradução Carlos Bernal Pulido. Bogotá: Universidad Externado de Colombia, 2003, p. 222.

${ }^{123}$ PRUDENTE, Eunice Aparecida de Jesus. Experiências integradoras que o Brasil já conheceu: uma análise jurídica sobre a exclusão social dos afro-descendentes numa ordem constitucional integradora. In: DURHAM, Eunice R.; BorI, Carolina M. (Org.). Seminário: O Negro no Ensino Superior. São Paulo: Núcleo de Pesquisas sobre Ensino Superior, 2003, p. 109.

124 Cf. Bossuyt, Marc. Prevention of discrimination: the concept and practice of affirmative action. Relatório final apresentado à comissão de Direitos Humanos do Conselho Econômico e Social das Nações Unidas. New York: ECOSOC, 2002, p. 2-3. 


\subsection{A máxima da proporcionalidade}

Muito já se falou a respeito da estrutura dos princípios e das colisões entre si. Contudo, ainda não foi descrito nenhum instrumento destinado a solucionar essas colisões. Esse instrumento é a máxima da proporcionalidade, que será explicada nesta seção.

De início, cumpre ressaltar que, embora a teoria da proporcionalidade utilizada neste trabalho tenha suas origens na Alemanha ${ }^{125}$ - mais especificamente, na análise da própria jurisprudência do tribunal constitucional daquele país -, não se trata de uma mera "importação" de conceitos e métodos incompatíveis com o ordenamento jurídico brasileiro. Primeiramente porque, como já se abordou, há alguns pontos de contato entre as constituições do Brasil e da Alemanha, sendo um dos mais importantes o próprio enunciado da igualdade. Além do mais, a jurisprudência do tribunal constitucional alemão e a do STF reconhecem que colisões entre princípios devem ser resolvidas pela proporcionalidade - muito embora não haja consenso sobre como se aplica a proporcionalidade. Por fim, a teoria da proporcionalidade, assim como toda a teoria dos princípios, "[s]e trata, sin embargo, de un modelo dogmático iusfundamental que, mutatis mutandi, es aplicable a otras constituciones, a derechos fundamentales supranacionales o a derechos humanos."126

O STF tem utilizado a máxima da proporcionalidade como meio de se resolver a colisão entre princípios. Contudo, não o faz baseando-se em uma teoria única, o que gera dúvidas quanto à definição de proporcionalidade, provocando insegurança. H. ÁvILA identifica ao menos cinco noções de proporcionalidade utilizadas pelo STF: limite à violação de um direito fundamental, exigência de racionalidade da decisão judicial, relação entre a agravante de um crime e a pena aplicada, proibição do excesso de uma lei em relação ao seu fim e desproporção entre o custo do serviço e a taxa cobrada (sinônimo da

\footnotetext{
125 Não é equivalente à proportionality da suprema corte norte-americana, portanto. Cf. SILVA, Virgilio Afonso da. O proporcional e o razoável. Revista dos Tribunais, São Paulo, a. 91 , n. 798, p. 23-50, abr. 2002, p. 30 .

126 BorowsKi, Martin. La restricción de los derechos fundamentales. Tradução Rodolfo Arango. Revista Española de Derecho Constitucional, Madrid, a. 20, n. 59, p. 29-56, mayo/agosto 2000, p. 30.
} 
equivalência na esfera tributária) ${ }^{127}$. V. SILVA identifica na jurisprudência do STF, ainda, a identificação da proporcionalidade com a razoabilidade ${ }^{128}$. Assim como ocorre com o vocábulo "princípio", o vocábulo "proporcionalidade" também é polissêmico, mesmo no discurso jurídico. Cumpre, portanto, analisar como se dá a resolução de uma colisão entre princípios e qual é a estrutura da máxima da proporcionalidade.

Os princípios, como já se abordou, são mandamentos de otimização: devem ser realizados na maior medida possível. Há, portanto, o dever de se realizar um princípio qualquer de forma ótima, sem sacrifícios desnecessários ou injustificados. Seguindo-se essa linha, é de certo modo intuitivo que uma intervenção em um princípio não será "legítima" ou "necessária" se não houver uma razão que a justifique e que essa razão seja "mais importante" que a limitação ao princípio em questão. Também se pode inferir que, se houver outro meio para se atingir aquilo que se pretende sem a restrição ou com restrição menor ao princípio em questão, a restrição mais gravosa "sacrifica desnecessariamente" a realização do princípio limitado. Dessa maneira, da própria estrutura dos princípios se deduz o "dever de proporcionalidade" ou "máxima da proporcionalidade". A máxima da proporcionalidade é uma consequência lógica da estrutura dos princípios da forma como é estabelecida pela teoria dos princípios ${ }^{129}$.

A máxima da proporcionalidade é uma regra de aplicação do Direito, uma metaregra, uma regra especial, ou um postulado normativo aplicativo ${ }^{130}$. Diz-se que é uma "regra" de aplicação porque, embora não seja uma regra de conduta tal qual apresentada

127 ÁvilA, Humberto. A distinção entre princípios e regras e a redefinição do dever de proporcionalidade. Revista Diálogo Jurídico, Salvador, a. 1., n. 4, jul. 2001. Disponível em: <http://www.direitopublico.com.br/ pdf_4/DIALOGO-JURIDICO-04-JULHO-2001-HUMBERTO-AVILA.pdf $>$. Acesso em: 29 de outubro de 2009 , p. 3-4.

${ }^{128}$ SILVA, Virgilio Afonso da. O proporcional e o razoável. Revista dos Tribunais, São Paulo, a. 91 , n. 798 , p. 23-50, abr. 2002, p. 31 .

129 “[...] A natureza dos princípios implica a máxima da proporcionalidade, e essa implica aquela.” ALEXY, Robert. Teoria dos direitos fundamentais. Tradução Virgílio Afonso da Silva. São Paulo: Malheiros, 2008 , p. 116. No mesmo sentido: Borowski, Martin. La estructura de los derechos fundamentales. Tradução Carlos Bernal Pulido. Bogotá: Universidad Externado de Colombia, 2003, p. 129. SILVA, Virgilio Afonso da. O proporcional e o razoável. Revista dos Tribunais, São Paulo, a. 91, n. 798, p. 23-50, abr. 2002, p. 43.

130 “O chamado princípio da proporcionalidade não consiste num princípio, mas num postulado normativo aplicativo. A partir dessa constatação ficará claro porque a tentativa de explicação do seu fundamento jurídico-positivo de validade tem sido tão incongruente: é que ele não pode ser deduzido ou induzido de um ou mais textos normativos, antes resulta, por implicação lógica, da estrutura das próprias normas jurídicas estabelecidas pela Constituição brasileira [...]" ÁvilA, Humberto. A distinção entre princípios e regras e a redefinição do dever de proporcionalidade. Revista Diálogo Jurídico, Salvador, a. 1, n. 4, jul. 2001. Disponível em: <http://www.direitopublico.com.br/pdf_4/DIALOGO-JURIDICO-04-JULHO-2001HUMBERTO-AVILA.pdf>. Acesso em: 29 de outubro de 2009, p. 4. 
por ocasião da distinção entre regras e princípios, também se aplica por subsunção, no "tudo-ou-nada". Há, portanto, quem prefira chamá-la de "máxima da proporcionalidade"131, de "regra da proporcionalidade"132, ou de "dever de proporcionalidade" ${ }^{133}$. O nome pouco importa - os termos podem ser utilizados de forma intercambiável -, desde que se tenha em mente que deve ser aplicado como uma regra, por subsunção, o que exclui, desde já, a denominação "princípio da proporcionalidade", de longe a mais frequente na doutrina e jurisprudência brasileiras.

A função da máxima da proporcionalidade é fornecer os critérios para que a intervenção a um princípio seja considerada justificada ou legítima - para que seja uma restrição, e não uma violação. Toda intervenção em um princípio deve passar pelo exame da proporcionalidade ( $=$ proporcionalidade em sentido amplo). A máxima da proporcionalidade fornece o instrumental necessário para a otimização dos princípios, e, nesse sentido, se assemelha ao "princípio" "134 da concordância prática de K. HeSSE, que consagra que "[...] a ambos os bens devem ser traçados limites, para que ambos possam chegar a eficácia ótima.",135

A máxima da proporcionalidade se divide em três elementos ou sub-regras, a saber: adequação, necessidade e proporcionalidade em sentido estrito. A análise de cada um dos elementos deve ocorrer nessa ordem e, por essa razão, V. SILVA chama a atenção para a relação de subsidiariedade, já que a aplicação da máxima da proporcionalidade nem

\footnotetext{
${ }^{131}$ Cf. Alexy, Robert. Teoria dos direitos fundamentais. Tradução Virgílio Afonso da Silva. São Paulo: Malheiros, 2008, p. 116-120. Informa V. SILVA que o termo "máxima da proporcionalidade" é a tradução direta do termo em alemão utilizado por R. ALEXY, mas pode ser menos apropriado que o termo "regra da proporcionalidade" - por ele preferido - porque passa ao leitor brasileiro a ideia de que se trata de mera recomendação, e não de um dever; não obstante, neste trabalho dar-se-á preferência ao termo traduzido mais fiel ao original. Cf. Silva, Virgílio Afonso da. Direitos fundamentais: conteúdo essencial, restrições e eficácia. $2^{\mathrm{a}}$ ed. São Paulo: Malheiros, 2010, p. 168.
}

${ }^{132}$ Cf. Silva, Virgílio Afonso da. Direitos fundamentais: conteúdo essencial, restrições e eficácia. $2^{\mathrm{a}}$ ed. São Paulo: Malheiros, 2010, p. 168-169.

${ }^{133}$ Cf. Ávila, Humberto. A distinção entre princípios e regras e a redefinição do dever de proporcionalidade. Revista Diálogo Jurídico, Salvador, a. 1, n. 4, jul. 2001. Disponível em: <http://www.direitopublico.com.br/ pdf_4/DIALOGO-JURIDICO-04-JULHO-2001-HUMBERTO-AVILA.pdf 3 . Acesso em: 29 de outubro de 2009, p. 23-24.

${ }^{134}$ No excerto, a palavra "princípio" não se refere ao conceito de princípios enquanto mandamento de otimização, conforme a distinção feita neste trabalho; seria melhor interpretada como "máxima", da mesma forma que a proporcionalidade.

${ }^{135}$ Hesse, Konrad. Elementos de Direito Constitucional da República Federal da Alemanha. Tradução Luís Afonso Heck. Porto Alegre: Sergio Antonio Fabris, 1998, p. 66. 
sempre implica a análise de todas os referidos elementos ${ }^{136}$. Logo, se for constatado que uma medida que intervém em um princípio não é adequada, será considerada desproporcional, não sendo necessário averiguar sua necessidade e sua proporcionalidade em sentido estrito, e assim por diante.

A adequação - ou idoneidade - de uma medida diz respeito ao fato de ela fomentar ou promover um objetivo constitucionalmente previsto; contribuir, qualquer que seja o grau da contribuição, para a realização desse objetivo. Em outras palavras, "[...] la adecuación es la persecución de un fin legítimo." ${ }^{137}$ Cumpre dizer que a medida $m$ não será adequada ao objetivo $O$ se não fomentar em nenhum aspecto a realização desse objetivo. $\mathrm{O}$ objetivo constitucionalmente determinado pode ser requerido por um princípio constitucional ou se confundir totalmente com ele ${ }^{138}$.

O exame da adequação é um exame absoluto, pois não se compara a medida examinada com as demais medidas que fomentam o mesmo objetivo, mas apenas a relação entre meio e fim. A análise da adequação pode parecer muito fácil, até mesmo óbvia, e é possível imaginar uma infinitude de casos absurdos em que a inadequação é patente. Contudo, em alguns casos pode ser necessário recorrer a campos científicos altamente especializados e a estudos complexos para se concluir pela adequação ou inadequação de certa medida $^{139}$, como no caso da pesagem de botijões de gás. Nesse caso, o STF manifestou-se pela inadequação de uma lei estadual que determinava, com o objetivo de coibir fraudes, a pesagem dos botijões de gás à vista do consumidor, devendo o comerciante - inclusive os caminhões que efetuassem as vendas a domicílio - portar balança de precisão. A medida foi considerada inadequada porque exigiria balanças de

${ }^{136}$ Cf. SILVA, Virgilio Afonso da. O proporcional e o razoável. Revista dos Tribunais, São Paulo, a. 91, n. 798, p. 23-50, abr. 2002, p. 34.

${ }^{137}$ BorowsKI, Martin. La restricción de los derechos fundamentales. Tradução Rodolfo Arango. Revista Española de Derecho Constitucional, Madrid, a. 20, n. 59, p. 29-56, mayo/agosto 2000, p. 38.

${ }^{138}$ Cf. AlEXY, Robert. Teoria dos direitos fundamentais. Tradução Virgílio Afonso da Silva. São Paulo: Malheiros, 2008, p.120.

139 “É bem de ver que, salvo diante de situações extremas, o intérprete jurídico dificilmente terá condições de avaliar, sozinho, se a política pública adotada pela autoridade é minimamente eficiente. Neste ponto, será indispensável a comunicação do Direito com outros ramos do conhecimento, que poderão fornecer essa espécie de informação ao jurista com consciência científica." BARCELlOS, Ana Paula de. Neoconstitucionalismo, direitos fundamentais e controle das políticas públicas. In: CAMARGO, Marcelo Novelino (Org.). Leituras complementares de direito constitucional: direitos humanos e direitos fundamentais. $3^{\text {a }}$ ed. Salvador: JusPodivm, 2008, p. 147. 
precisão extremamente sensíveis que poderiam se desregular com a trepidação dos veículos, inclusive prejudicando o consumidor ${ }^{140}$.

Passado o exame da adequação, ou seja, considerando-se que a medida $m$ fomenta, em qualquer aspecto, o objetivo $O$ estabelecido pelo princípio $P_{1}$ - ainda de restrinja os princípios $P_{2} \ldots P_{n}$, passa-se ao exame da necessidade de tal medida. Trata-se de um exame fundamentalmente comparativo, pois se deve analisar a medida $m$ em conjunto com as demais medidas que sirvam ao fomento do mesmo objetivo $O$. Conclui-se que uma medida não é necessária se houver outras medidas que fomentem o objetivo $O$ em igual ou maior intensidade, mas que restrinjam menos os princípios $P_{2} \ldots P_{n}$ :

\begin{abstract}
Una medida estatal no es necesaria si su finalidad también puede ser alcanzada por otro medio por lo menos igualmente eficaz, y que a la vez no restrinja el derecho fundamental afectado o lo restrinja con una intensidad menor. Debe aclararse que no podrán considerarse como medios alternativos, todos aquellos que cumplan los presupuestos en esta definición, pero que a la vez afecten a otras posiciones constitucionales. ${ }^{141}$
\end{abstract}

Dada a definição acima exposta, percebe-se que o exame da necessidade não significa a obrigatoriedade de eleição do meio menos gravoso, que só será obrigatório se as medidas comparadas forem igualmente eficientes no fomento do objetivo $O^{142}$. Se a medida $m_{1}$ fomenta o princípio $P_{1}$ com grau de intensidade maior que a medida $m_{2}$, embora $m_{2}$ restrinja menos o princípio $P_{2}$, não se pode inferir que $m_{1}$ não seja necessária. No caso, se o exame da necessidade consistisse na obrigatoriedade do meio menos gravoso, deverse-ia eleger $m_{2}$.

Neste ponto, convém criar um exemplo para melhor ilustrar o afirmado, muito embora as conclusões parciais a que se chegarão carecem da correção que um exame exaustivo - possível apenas em uma monografia ou em um processo judicial que tratasse exclusivamente do exemplo - poderia proporcionar. É sabido que o direito à saúde é uma norma de direito fundamental com a estrutura de princípio, assim como o é o direito à liberdade. Suponha-se que o legislador, com o objetivo de fomentar o direito à saúde $\left(P_{1}\right)$, que exige, entre outros objetivos, o de se reduzir os acidentes de trânsito $(O)$, decida

\footnotetext{
${ }^{140}$ Cf. ADI 882/PR.

${ }^{141}$ BorowsKI, Martin. La estructura de los derechos fundamentales. Tradução Carlos Bernal Pulido. Bogotá: Universidad Externado de Colombia, 2003, p. 130.

${ }^{142}$ Cf. Silva, Virgílio Afonso da. Direitos fundamentais: conteúdo essencial, restrições e eficácia. $2^{\mathrm{a}}$ ed. São Paulo: Malheiros, 2010, p. 172.
} 
proibir totalmente o tráfego de veículos automotores $\left(m_{1}\right)$. Nesse caso hipotético, o legislador procurou solucionar uma colisão entre o direito à saúde $\left(P_{1}\right)$ e o direito à liberdade de tráfego $\left(P_{2}\right)$, solucionando-a, nesse caso, em favor do primeiro. A medida $m_{1}$ é adequada, pois se observa que nem é preciso um exame aprofundado para se concluir que os acidentes de trânsito serão drasticamente reduzidos - ou até mesmo eliminados - com a proibição do tráfego de veículos automotores. Quanto ao exame da necessidade, supõe-se que $m_{1}$ fomente o objetivo $O$ com maior intensidade que qualquer outra medida destinada a favorecer o mesmo objetivo, como, por exemplo, o estabelecimento de lei que obriga a instalação e o uso dos equipamentos de segurança nos veículos $\left(m_{2}\right)$. A medida $m_{1}$, conquanto restrinja em muito maior intensidade o direito à liberdade de locomoção $\left(P_{2}\right)$ que $m_{2}$, demonstra ser necessária. Ser necessária, nesse caso, não significa que deva ser adotada: $m_{1}$ passou nos testes da adequação e da necessidade, mas dificilmente resistiria ao exame da proporcionalidade em sentido estrito, que se presta a "[...] evitar que medidas estatais, embora adequadas e necessárias, restrinjam direitos fundamentais além daquilo que a realização do objetivo perseguido seja capaz de justificar."143

No terceiro elemento da máxima da proporcionalidade - o exame da proporcionalidade em sentido estrito -, a dimensão do peso característica dos princípios se faz presente. É nessa fase que se procede ao sopesamento ( = ponderação) entre os princípios colidentes, nos termos da lei da colisão $\left(\left(\begin{array}{llll}P_{1} & \mathbf{P} & P_{2}\end{array}\right) C\right)$, momento em que a argumentação jurídica assume função central.

No exame da proporcionalidade em sentido estrito, deve-se analisar a medida à luz da "lei do sopesamento": "[q]uanto maior for o grau de não-satisfação ou de afetação de um princípio, tanto maior terá que ser a importância da satisfação do outro." ${ }^{\text {144 }}$ Isso implica estabelecer enunciados que digam respeito ao grau de afetação e à importância dos princípios, o que só pode ser levado a cabo mediante o recurso a qualquer meio de argumentação jurídica, ou seja, devem ser fundamentados de qualquer forma juridicamente possível, como mediante referências a fatos, juízos normativos, etc ${ }^{145}$. No exemplo exposto anteriormente, há inúmeros argumentos no sentido de que a afetação do direito à liberdade

${ }^{143}$ SILVA, Virgílio Afonso da. Direitos fundamentais: conteúdo essencial, restrições e eficácia. $2^{\text {a }}$ ed. São Paulo: Malheiros, 2010, p. 175.

144 AleXy, Robert. Teoria dos direitos fundamentais. Tradução Virgílio Afonso da Silva. São Paulo: Malheiros, 2008, p. 167.

145 Cf. AlEXY, Robert. Teoria dos direitos fundamentais. Tradução Virgílio Afonso da Silva. São Paulo: Malheiros, 2008, p. 171-172. 
$\left(P_{2}\right)$ assumiu um grau tão elevado que não se justifica pela importância da satisfação do direito à saúde $\left(P_{1}\right)$, porque a economia nacional entraria em colapso por conta da dependência do transporte rodoviário $\left(\mathrm{r}_{1}\right)$, porque dezenas de milhões de indivíduos teriam sua locomoção impedida ou dificultada em razão do fomento à saúde para alguns milhares de pessoas $\left(\mathrm{r}_{2}\right)$, porque a estrita obediência às leis de trânsito e o uso dos equipamentos de segurança já são suficientes a fomentar a saúde, sendo os acidentes viários decorrência do descumprimento dessas normas $\left(r_{3}\right)$, etc $\left(r_{n}\right)$.

A noção de sopesamento, elemento fundamental da teoria dos princípios, é alvo de inúmeras críticas, que variam da arbitrariedade ao se atribuir pesos para a comparação entre princípios $^{146}$ a de ser um método subjetivista e irracional ${ }^{147}$. J. HABERMAS, no que concerne à comparação entre princípios caso a caso, chega a afirmar que, "[b]ecause there are no rational standards for this, weighing takes place either arbitrarily or unreflectively $[\ldots]^{, 148}$. Essas críticas, ainda que possam valer para a aplicação equivocada da teoria dos princípios - o que costuma ocorrer nos tribunais do Brasil -, não são cabíveis contra a teoria em si.

Primeiramente, porque o método do sopesamento não ocorre em todos os casos em que há colisão entre princípios. Ocorre somente no último passo do exame da proporcionalidade em sentido amplo. Isso ocorre porque o exame da adequação e o exame da necessidade dizem respeito às possibilidades fáticas de realização dos princípios, tendose em vista que os princípios devem ser realizados na maior medida possível, dentro das possibilidades fáticas e jurídicas existentes. $\mathrm{Na}$ proporcionalidade em sentido estrito, por sua vez, delineiam-se as possibilidades jurídicas, compostas principalmente pelos princípios ou bens colidentes ${ }^{149}$. Não obstante, mesmo o exame da adequação e o exame da necessidade não são matemáticos, mas, pelo contrário, exigem argumentação - embora não

\footnotetext{
${ }^{146}$ Cf. Aleinikoff, Thomas Alexander. Constitutional Law in the Age of Balancing. The Yale Law Journal, New Haven, v. 96, n. 5, p. 943-1005, Apr. 1987, p. 973.

${ }^{147}$ Cf. SchlinK, Bernhard. Der Grundsatz der Verhältnismäßigkeit. In: BADURA, Peter; DrEIER, Horst (Edit.). Festschrift 50 Jahre Bundesverfassungsgericht. Tübingen: Mohr Siebeck, 2001, p. 460 apud ALEXY, Robert. On Balancing and Subsumption: a Structural Comparison. Ratio Juris, Malden, v. 16, n. 4, p. 433449, Dec. 2003, p. 436.

${ }^{148}$ HABERMAS, Jürgen. Between Facts and Norms: contributions to a discourse theory of law and democracy. Tradução William Rehg. Cambridge: Massachusetts Institute of Technology Press, 1996, p. 259.

${ }^{149}$ Cf. Ávila, Humberto. A distinção entre princípios e regras e a redefinição do dever de proporcionalidade. Revista Diálogo Jurídico, Salvador, a. 1, n. 4, jul. 2001. Disponível em: <http://www.direitopublico.com.br/ pdf_4/DIALOGO-JURIDICO-04-JULHO-2001-HUMBERTO-AVILA.pdf $>$. Acesso em: 29 de outubro de 2009, p. 12.
} 
com a mesma intensidade -, especialmente por conta da incerteza inerente às prognoses empíricas $^{150}$. O relevante, contudo, é o fato de serem exames que não se fundam no sopesamento entre princípios:

\begin{abstract}
Con los primeros dos principios [sub-regras] del juicio de proporcionalidad (en sentido amplio), o sea con los principios [sub-regras] de suficiencia [ = adequação] y necesidad, se dispone de dos criterios, aplicables sin ponderación alguna, con los cuales es posible resolver la colisión de principios. Si aquéllos no bastan para decidir, se debe fundamentar una relación de precedencia condicionada en la ponderación de los principios en colisión. La fundamentación de esa relación de precedencia no puede resolverse por vía de la teoría de principios. Se requiere, adicionalmente, una fundamentación desde la perspectiva de una teoría externa a la teoría de principios, esto es, una teoría de la argumentación jurídico-racional. ${ }^{151}$
\end{abstract}

$\mathrm{Na}$ verdade, as principais críticas ao sopesamento enquanto modo de resolução de colisões entre princípios - à máxima da proporcionalidade, que se utiliza do sopesamento em seu último passo - são formuladas por conta de certo desconhecimento acerca da estrutura e dos pressupostos do sopesamento e pela aplicação inadequada da teoria nos tribunais, inclusive no STF. G. LIMA critica a aplicação equivocada da teoria de R. ALEXY no Brasil, onde se tornou exatamente o que não é: um meio simples para que o Judiciário tome decisões sem precisar fundamentá-las suficientemente. Em outras palavras, decide-se contra uma medida, ou a favor dela, e justifica-se essa decisão porque a medida é “desproporcional” ou "proporcional”, sem nada mais dizer:

\begin{abstract}
Por isso, todas as críticas que geralmente são feitas à técnica da ponderação - por ser irracional, pouco transparente, arbitrária, subjetiva, antidemocrática, imprevisível, insegura e por aí vai - são, em grande medida, procedentes diante da realidade brasileira. Entre nós, vigora a teoria da Katchanga, já que ninguém sabe ao certo quais são as regras do jogo. Quem dá as cartas é quem define quem vai ganhar, sem precisar explicar os motivos. ${ }^{152}$
\end{abstract}

\footnotetext{
${ }^{150} \mathrm{Cf}$. "Se o dador de leis somente em virtude de suposições empíricas absolutamente certas pudesse atuar, ele, em vista da incerteza da maioria das prognoses empíricas, de modo algum mais poderia atuar." ALEXY, Robert. Constitucionalismo Discursivo. $2^{\mathrm{a}}$ ed. Tradução Luís Afonso Heck. Porto Alegre: Livraria do Advogado, 2008, p. 13.

151 BorowsKi, Martin. La restricción de los derechos fundamentales. Tradução Rodolfo Arango. Revista Española de Derecho Constitucional, Madrid, a. 20, n. 59, p. 29-56, mayo/agosto 2000, p. 38. Atente-se novamente pelo uso, no excerto, do termo "princípio" da suficiência e "princípio" da necessidade. Não são princípios no sentido exposto nesse trabalho, e seriam melhor entendidos como sub-regras (sub-regras da máxima da proporcionalidade).

${ }^{152}$ LimA, George Marmelstein. Alexy à Brasileira ou a Teoria da Katchanga. Direitos Fundamentais, [S.1.], 2008. Disponível em <http://direitosfundamentais.net/2008/09/18/alexy-a-brasileira-ou-a-teoria-dakatchanga/>. Acesso em 23 de setembro de 2009, p. 2.
} 
De fato, os tribunais "[...] podem se utilizar disso [do sopesamento] para mascarar o caráter decisionista de seus julgamentos." ${ }^{, 153}$ No entanto, uma decisão que conclua pela "proporcionalidade" ou "desproporcionalidade" de certa medida baseando-se em meras conjecturas, apelos ao senso comum ou simples intuições não se utiliza, rigorosamente, do método do sopesamento. Esse método não é uma simples comparação entre dois ou mais princípios colidentes para se decidir qual ou quais devem prevalecer nas circunstâncias expostas. Mais do que isso: trata-se de uma comparação discursivamente correta.

O método do sopesamento não é um método irracional. Pelo contrário, "[e]1 concepto de ponderación, ligado con la teoría de los principios, permite que la decisión de preguntas normativas se lleve a cabo en el nivel analítico más alto posible que hasta hoy se conoce." ${ }^{154}$ Levando-se a questão do sopesamento para a teoria do discurso aplicada ao Direito, seguindo-se as regras pragmáticas do discurso, certo é não se chagar sempre a uma certeza conclusiva, mas isso não significa que a resposta não seja racional:

\begin{abstract}
A observação dessas regras [regras pragmáticas] certamente não garante a certeza conclusiva de todos os resultados, mas sem dúvida define os resultados como resultados racionais. A racionalidade, então, não deve ser equiparada à certeza conclusiva. Isso caracteriza a idéia básica da teoria do discurso racional prático. $^{155}$
\end{abstract}

O discurso jurídico, versão mais restrita do discurso prático geral, trata de buscar os fundamentos das afirmações normativas. Essas afirmações não podem ser reduzidas a objetos empíricos, mas também não são meros objetos da intuição de seu articulador. Devem ser testadas no discurso mediante a avaliação das razões que justificam tais afirmações normativas por intermédio das regras pragmáticas ${ }^{156}$, que podem dizer respeito

153 AlEXY, Robert. Teoria dos direitos fundamentais. Tradução Virgílio Afonso da Silva. São Paulo: Malheiros, 2008, p. 581.

${ }^{154}$ BorowsKI, Martin. La estructura de los derechos fundamentales. Tradução Carlos Bernal Pulido. Bogotá: Universidad Externado de Colombia, 2003, p. 142.

${ }^{155}$ AleXY, Robert. Teoria da argumentação jurídica. Tradução Zilda Hutchinson Schild Silva. São Paulo: Landy, 2001, p. 181.

156 As quatro regras básicas seriam: (i) nenhum orador pode se contradizer, (ii) todo orador apenas pode afirmar aquilo que crê, (iii) todo orador que aplique um predicado $\mathrm{F}$ a um objeto $a$ tem de estar preparado para aplicar F a todo outro objeto que seja semelhante a $a$ em todos os aspectos importantes, e (iv) diferentes oradores não podem usar a mesma expressão com diferentes significados. Cf. AlEXY, Robert. Teoria da argumentação jurídica. Tradução Zilda Hutchinson Schild Silva. São Paulo: Landy, 2001, p. 187. O autor informa ter descrito 28 regras do discurso, tão completamente quanto possível. Cf. AlEXY, Robert. Direito, Razão, Discurso: Estudos para a filosofia do direito. Tradução Luís Afonso Heck. Porto Alegre: Livraria do Advogado, 2010, p. 89. 
à exigência de racionalidade, de universalidade, de claridade linguística ou de verdade empírica. Configura-se, portanto, uma teoria procedimental de correção prática que visa a estabelecer a imparcialidade do discurso mediante a liberdade e igualdade na $\operatorname{argumentação~}^{157}$.

Há uma estreita ligação entre o sopesamento e a teoria do discurso de R. AlEXY. Não é o objetivo deste trabalho adentrar nos meandros da teoria do discurso prático, mas apenas informar que o sopesamento não é irracional, muito embora não forneça sempre uma resposta dotada de certeza:

De existir un procedimiento decisorio intersubjetivo y obligatorio en materia de preguntas normativas, tendría éste que preferirse a la ponderación. Pero un 'mejor' procedimiento con estas características no existe y tampoco está a la vista. En estas circunstancias, es preferible el procedimiento relativamente mejor, y este es precisamente el concepto de la ponderación. ${ }^{158}$

Assim como uma situação de discurso ideal, em que, inter alia, todos possam participar sem constrangimentos e expor seus argumentos, além de poderem pedir explicações sobre os argumentos dos outros participantes, não é possível na prática ${ }^{159}$, principalmente por conta da necessidade de se chegar a uma resposta em um determinado espaço de tempo, uma resposta "ideal” também não é possível na prática. Contudo, quanto mais o discurso se aproximar da situação ideal, mais próxima da resposta "ideal" estará a resposta obtida. Assim, não é incorreto entender que, na solução de questões normativas, se trabalha com altas probabilidades, mas não com a certeza da correção da resposta, que, aliás, pode ser posteriormente falseada.

No caso específico da igualdade, a discussão acerca da racionalidade do sopesamento e da argumentação que o sustenta assume relevo por conta do alerta de I. BERLIN ao afirmar que a fórmula da razão suficiente que justifica um tratamento desigual seria reduzida a uma tautologia se não lhe for conferida um sentido específico ${ }^{160}$. E.

157 Cf. AleXY, Robert. Teoría del discurso y derechos humanos. Tradução Luis Villar Borda. Bogotá: Universidad Externado de Colombia, 2005, p. 66-68.

158 BorowsKi, Martin. La restricción de los derechos fundamentales. Tradução Rodolfo Arango. Revista Española de Derecho Constitucional, Madrid, a. 20, n. 59, p. 29-56, mayo/agosto 2000, p. 46.

${ }^{159}$ Cf. Alexy, Robert. Direito, Razão, Discurso: Estudos para a filosofia do direito. Tradução Luís Afonso Heck. Porto Alegre: Livraria do Advogado, 2010, p. 90.

160 “[...] unless some specific sense is given to 'sufficient reason', the principle can be reduced to a trivial tautology [...].” Berlin, Isaiah. Equality. Proceedings of the Aristotelian Society, London, new series v. 56, p. 321-326, 1955/1956, p. 303. 
FORSTHOFF, por sua vez, conclui que da fórmula da razão suficiente não se deduz de concreto "absolutamente nada" ". Com efeito, "[s]aber o que é uma razão suficiente [...] não é algo que o enunciado da igualdade, enquanto tal, pode responder."162 O sentido específico que se dá à fórmula da razão suficiente está fora do enunciado da igualdade: está na racionalidade do discurso.

A observação das regras do discurso racional aumenta a probabilidade de se atingir um resultado correto em qualquer discussão. Mas "[n]ão se pode dizer com base nessas regras e formas apenas [...] quais devam ser os resultados."163 Em certas ocasiões, inclusive, pode-se chegar a uma pluralidade de respostas que satisfaçam aos critérios de correção. Em outras palavras, e ao contrário do que sustenta R. DWORKIN ${ }^{164}$, não há sempre apenas uma resposta correta a uma questão normativa ${ }^{165}$. Conforme R. ALEXY, “[a] natureza do direito constitucional permite somente escalações relativamente rudes dos pesos que se encontram em jogo na ponderação. Isso leva a numerosos empates de ponderação e, com isso, a numerosos espaços de ponderação." ${ }^{166}$ Dentro desses espaços de ponderação, o legislador pode optar por qualquer uma das respostas que satisfaçam os critérios de correção utilizando-se da conveniência e oportunidade políticas, ou seja, pode decidir discricionariamente. As escalações dos pesos não são finamente estabelecidas pode-se estabelecer, por exemplo, uma escala triádica de intervenção: fraca, média e forte -, de modo que os espaços de ponderação são relativamente frequentes. E são os espaços de ponderação justamente um dos motivos pelos quais o legislador democraticamente legitimado tem uma margem de manobra e de decisão - não é um mero "executor" da constituição:

${ }^{161}$ Forsthoff, Ernst. El Estado de la sociedad industrial. Tradução Luis López Guerra e Jaime Nicolás Muñiz. Madrid: Instituto de Estudios Políticos, 1975, p. 229.

162 AlEXY, Robert. Teoria dos direitos fundamentais. Tradução Virgílio Afonso da Silva. São Paulo: Malheiros, 2008, p. 411.

163 AleXY, Robert. Teoria da argumentação jurídica. Tradução Zilda Hutchinson Schild Silva. São Paulo: Landy, 2001, p. 238-239.

${ }^{164}$ Cf. DwORKIN, Ronald. No right answer? New York University Law Review, New York, v. 53, n. 1, p. 132, Apr. 1978, p. 3 et seq.

165، As respostas às questões práticas não se baseiam apenas, porém essencialmente, nas interpretações de interesses e nas avaliações dos mesmos. Não podemos aceitar, nessa base, que só exista uma única resposta possível para cada pergunta prática." AlEXY, Robert. Teoria da argumentação jurídica. Tradução Zilda Hutchinson Schild Silva. São Paulo: Landy, 2001, p. 310-311.

${ }^{166}$ AleXY, Robert. Constitucionalismo Discursivo. $2^{\mathrm{a}}$ ed. Tradução Luís Afonso Heck. Porto Alegre: Livraria do Advogado, 2008, p. 83. 
Para o que aqui interessa, é preciso que se atente ao seguinte ponto: se a teoria dos princípios não defende que para todos os problemas envolvendo direitos a uma única resposta correta e, mais do que isso, que não é possível encontrar as respostas a todos esses problemas na própria constituição, pois ela e os direitos fundamentais nela consagrados deixam "espaços abertos", que serão preenchidos, em primeira linha, pelo legislador $[\ldots]^{167}$

A teoria dos princípios recebe críticas de quem entende tratar-se de uma teoria que, em última análise, retira a legitimidade do parlamento democraticamente eleito enquanto foro preferencial para a discussão das questões normativas transferindo-as ao Judiciário, que é o órgão que dá a palavra final sobre questões normativas. A atividade do legislador estaria reduzida a apenas constatar ou explicitar o que já foi decidido na própria constituição, que seria uma espécie de "ovo jurídico" de onde tudo surge, nas palavras de E. FORSTHOFF ${ }^{168}$. Essa crítica seria correta apenas se fosse válida a hipótese de que todas as respostas normativas estivessem contidas, expressa ou implicitamente, na constituição, pois somente haveria uma resposta que satisfizesse o grau ótimo de realização dos princípios constitucionais.

Neste momento já se percebe que a teoria dos princípios é perfeitamente compatível coma noção de "constituição-moldura". A constituição, nesse sentido, tanto ordena ou proíbe quanto faculta algo ao legislador. As ordens e proibições constituiriam a moldura e o facultado residiria na moldura ${ }^{169}$. O que a constituição proíbe pode ser denominado de constitucionalmente impossível, o que ordena, de constitucionalmente necessário, e o que nem proíbe nem ordena, mas faculta, de constitucionalmente possível. O que R. ALEXY chama de "espaço estrutural" é definido justamente pela ausência de ordens ou proibições definitivas na constituição ${ }^{170}$. Há três tipos de espaços estruturais ${ }^{171}$, mas o que interessa neste momento é o espaço de ponderação: se os pesos estabelecidos entre os princípios no

${ }^{167}$ Silva, Virgílio Afonso da. A constitucionalização do direito: os direitos fundamentais nas relações entre particulares. São Paulo: Malheiros, 2008, p. 123.

${ }^{168}$ Forsthoff, Ernst. El Estado de la sociedad industrial. Tradução Luis López Guerra e Jaime Nicolás Muñiz. Madrid: Instituto de Estudios Políticos, 1975, p. 242.

${ }^{169}$ Cf. AleXY, Robert. Constitucionalismo Discursivo. $2^{\mathrm{a}}$ ed. Tradução Luís Afonso Heck. Porto Alegre: Livraria do Advogado, 2008, p. 77.

${ }^{170}$ Cf. Alexy, Robert. Constitucionalismo Discursivo. $2^{\mathrm{a}}$ ed. Tradução Luís Afonso Heck. Porto Alegre: Livraria do Advogado, 2008, p. 79.

${ }^{171}$ Cf. AleXY, Robert. Constitucionalismo Discursivo. $2^{\mathrm{a}}$ ed. Tradução Luís Afonso Heck. Porto Alegre: Livraria do Advogado, 2008, p. 80 et seq. 
caso em análise forem desiguais, não há espaço de ponderação, que só surge no caso de "empate". No caso da igualdade, o legislador também tem essa margem de manobra nas hipóteses em que não há obrigatoriedade nem de um tratamento igual, nem desigual, mas permite tanto um quanto outro, se presentes razões suficientes que permitem um tratamento desigual $^{172}$.

Quanto ao método do sopesamento, é relevante mencionar que ele possui três passos:

\begin{abstract}
Essa fórmula [quanto maior for o grau de não-satisfação ou de afetação de um princípio, tanto maior terá que ser a importância da satisfação do outro] deixa reconhecer que a ponderação compõe-se de três passos. Em primeiro passo, deve ser comprovado o grau de não-cumprimento ou prejuízo de um princípio. Isto é, quando se trata da dimensão de defesa, a intensidade da intervenção. A isso tem de seguir, em um segundo passo, a comprovação da importância do cumprimento do princípio em sentido contrário. Em um terceiro passo, finalmente, deve ser comprovado se a importância do cumprimento do princípio em sentido contrário justifica o prejuízo ou não-cumprimento do outro. ${ }^{173}$
\end{abstract}

As comprovações a que o excerto faz alusão certamente devem seguir o procedimento do discurso jurídico racional para que o resultado se repute correto. Trata-se de uma análise, de certo modo, ampla e exaustiva. No entanto, nada impede que se dê um exemplo de como se pode operar o sopesamento em um caso concreto hipotético, supondose que os graus atribuídos sejam discursivamente corretos. Dessa forma, primeiramente, há que se demonstrar qual é o grau de afetação ou não-satisfação de um ou mais princípios. Ainda no exemplo da medida adequada e necessária que proibiu a circulação de veículos automotores $\left(m_{1}\right)$ com vistas ao objetivo de reduzir ou eliminar os acidentes viários $(O)$ determinado pelo direito à saúde $\left(P_{2}\right)$, e adotando-se uma simples escalação triádica, notase que a afetação ao princípio de liberdade de locomoção $\left(P_{1}\right)$ foi forte, pois o Brasil é um país altamente dependente do transporte rodoviário, inclusive no interior das principais cidades, muitas das quais não possuem sequer sistema de transporte coletivo sobre trilhos. Pode-se, ainda, alegar que houve uma afetação a outros princípios, como o direito à propriedade de quem possui veículos automotores, ou a liberdade de exercício profissional de categorias que dependem do transporte por veículos automotores, como os taxistas: conquanto esses elementos também viessem, em um caso real, a integrar o sopesamento,

${ }^{172}$ Cf. AleXY, Robert. Teoria dos direitos fundamentais. Tradução Virgílio Afonso da Silva. São Paulo: Malheiros, 2008, p. 413.

${ }^{173}$ AleXY, Robert. Constitucionalismo Discursivo. $2^{\mathrm{a}}$ ed. Tradução Luís Afonso Heck. Porto Alegre: Livraria do Advogado, 2008, p. 83. 
conferindo ainda maior peso nesse sentido, para simplificar a análise do exemplo, suponhase que apenas a liberdade de locomoção foi afetada. Posteriormente, deve-se demonstrar o grau de importância da realização do princípio prestigiado pela medida, no caso, o direito à saúde $\left(P_{2}\right)$ : certamente milhares de vidas serão poupadas e um número ainda maior de acidentes serão evitados, mas é possível a argumentação no sentido de que os acidentes viários constituem apenas uma fração das causas de morte ou de problemas de saúde, atribuindo-se um grau de importância médio à realização desse princípio. Neste ponto, percebe-se que a importância da realização de $P_{2}$ não justifica a afetação de $P_{1}$, de modo a concluir-se que $\left(\begin{array}{lll}P_{1} & \mathbf{P} & P_{2}\end{array}\right) \quad C$, sendo $m_{1}$ desproporcional e a lei que a estabelece, inconstitucional.

No que diz respeito à proporcionalidade de medidas que estabelecem tratamentos jurídicos desiguais, os passos sucessivos significam que se deve, primeiramente, averiguarse a intensidade de afetação ao princípio da igualdade jurídica e a outros princípios eventualmente afetados no caso em análise. Posteriormente, deve-se comprovar o grau de realização do princípio da igualdade fática e de outros princípios eventualmente fomentados pela medida. A terceira e última fase cuida de averiguar se a importância do cumprimento do princípio da igualdade fática justifica o prejuízo ou não-cumprimento do princípio da igualdade jurídica:

\begin{abstract}
Ahora bien, una vez se ha averiguado la intensidad del trato desigual, debe establecerse el peso de la razón que la justifica. Lo que debe averiguarse es qué razones hablan a favor de permitir la diferenciación desde el punto de vista objetivo del derecho constitucional. Como razones para tener en cuenta concurren todos los derechos y bienes del derecho constitucional, así como todos los fines relativos que el Estado persiga legítimamente. ${ }^{174}$
\end{abstract}

Neste ponto, já foram abordadas as principais premissas da teoria dos princípios: o suporte fático amplo, a diferença entre direito protegido prima facie e direito definitivo, a distinção entre regras e princípios e a máxima da proporcionalidade como forma de controle e aplicação dos princípios como mandamentos de otimização ${ }^{175}$. Pode-se prosseguir para a abordagem das ações afirmativas.

\footnotetext{
${ }^{174}$ Borowski, Martin. La estructura de los derechos fundamentales. Tradução Carlos Bernal Pulido. Bogotá: Universidad Externado de Colombia, 2003, p. 206-207.

${ }^{175}$ Cf. Silva, Virgílio Afonso da. Direitos fundamentais: conteúdo essencial, restrições e eficácia. $2^{\mathrm{a}}$ ed. São Paulo: Malheiros, 2010, p. 206.
} 


\section{CAPÍTULO 2 - DAS AÇÕES AFIRMATIVAS}

\subsection{Síntese histórica das ações afirmativas}

O termo "ações afirmativas" teve significados diversos em diferentes locais e em diferentes períodos ${ }^{176}$. Desde uma primeira fase, nos Estados Unidos, em que significava simplesmente a adesão passiva a determinações de não-discriminação, a uma fase, no contexto global, em que passou a significar uma complexa teia de medidas encorajadas ou levadas a cabo pelo Estado com o objetivo de promover a inclusão social de minorias, o termo adquiriu diversas acepções ao longo da história dos séculos XX e XXI. Torna-se fundamental discorrer, ainda que sucintamente, sobre essas diversas acepções, sempre com o objetivo de se chegar a uma definição satisfatória do instituto para a sua análise no contexto do presente trabalho.

Há quem identifique, aliás, a existência de políticas de preferências ou de quotas dirigidas a grupos mais vulneráveis - embora não denominadas ações afirmativas - que remonta ao século XIX e em lugares muito distantes dos Estados Unidos, como é o caso das preferências concedidas aos Maori, povo nativo da Nova Zelândia, pelo Tratado de Waitangi de $1840^{177}$. Em muitos casos, essas políticas seguiram diferentes lógicas e serviram a objetivos distintos: apesar de possuírem características em comum com as medidas de ação afirmativa, com elas não se confundem.

A Índia, segundo país mais populoso do mundo e lar de uma sociedade complexa e heterogênea, pode ser considerada a criadora do núcleo do que atualmente se entende por

\footnotetext{
${ }^{176}$ Cf. Sowell, Thomas. Affirmative Action Around the World: an Empirical Study. New Haven: Yale University Press, 2004, p. 123.

177 Cf. Sowell, Thomas. Affirmative Action Around the World: an Empirical Study. New Haven: Yale University Press, 2004, p. 1.
} 
ações afirmativas ${ }^{178}$. Esse país foi o grande pioneiro na adoção de políticas de quotas (reservations, mas também chamadas de affirmative action) ${ }^{179}$ a grupos em desvantagem. Sua constituição, promulgada em $1949^{180}$, proíbe a discriminação em virtude de sexo, religião, casta, raça, etc. No entanto, ressalva expressamente que a proibição da discriminação não pode impedir “[...] the State from making any special provision for the advancement of any socially and educationally backward classes of citizens or for the Scheduled Castes and the Scheduled Tribes" ${ }^{181}$, inclusive quanto ao acesso desses grupos a instituições de ensino, ainda que privadas ${ }^{182}$. Esses dispositivos constitucionais não são letra morta: ao longo dos anos, a Índia criou um vasto e complexo sistema de reservations, principalmente quanto ao acesso ao ensino e ao emprego em órgãos públicos. Atualmente, pode-se afirmar que “[...] a Índia é o país com a mais longa história e experiência de ações afirmativas no mundo [...]"183 e que sua experiência possui particularidades que a diferencia das demais, como a norte-americana:

\begin{abstract}
A la différence des Etats-Unis, où l'appartenance à un groupe est autodéclarée, le dispositif indien de reservations fonctionne sur la base de quotas pour des emplois dans la fonction publique, ou de places dans l'einsegnement, accordés à des groupes appartenants à certaines castes administrativement désignées. Ces quotas ne sont pas décidés par des organismes particuliers indépendants : c'est le gouvernement - celui de l'Union ou ceux des différents Etats - qui les fixe et, dès alors, ils sont obligatoires. ${ }^{184}$
\end{abstract}

A despeito da anterior experiência indiana, muitas das características e muitos dos limites jurídicos do que atualmente se entende por ações afirmativas foram delineados em

178 “A primeira formulação, portanto, das ações afirmativas, não surgiu das Ciências Sociais e Políticas ocidentais, mas da intelectualidade indiana que militava pela descolonização." CARVALHO, José Jorge de. Inclusão Etnica e Racial no Brasil: a questão das cotas no ensino superior. São Paulo: Attar, 2005, p. 184.

179 Cf. Sowell, Thomas. Affirmative Action Around the World: an Empirical Study. New Haven: Yale University Press, 2004, p. 23.

${ }^{180}$ Cf. Preâmbulo da Constituição da Índia. Disponível em: <http://lawmin.nic.in/coi/coiason29july08.pdf>. Acesso em: 21 de dezembro de 2009.

${ }^{181}$ Artigo 15 (4) da Constituição da Índia, com a redação dada pela Emenda $\mathrm{n}^{\mathrm{o}} 1$ de 1951 . Disponível em: $<$ http://lawmin.nic.in/coi/coiason29july08.pdf >. Acesso em: 21 de dezembro de 2009.

${ }^{182}$ Cf. Artigo 15 (5) da Constituição da Índia, com a redação dada pela Emenda ${ }^{\circ} 93$ de 2005. Disponível em: <http://lawmin.nic.in/coi/coiason29july08.pdf>. Acesso em: 21 de dezembro de 2009.

${ }^{183}$ CARVAlho, José Jorge de. Inclusão Étnica e Racial no Brasil: a questão das cotas no ensino superior. São Paulo: Attar, 2005, p. 185.

${ }^{184}$ Agrawal, Purushottam. En Inde, des quotas pour les basses castes. Le Monde diplomatique, Paris, a. 54, n. 638 , mai 2007, p. 12. 
um país sem previsão constitucional expressa que autoriza a adoção de tais medidas. Por meio de um conjunto de políticas implementadas originariamente pelo governo norteamericano a partir de meados do século XX em função das reivindicações dos movimentos pelos direitos civis, em especial dos negros norte-americanos, surgiu a influente affirmative action norte-americana. A partir da década de 1960, surgiu uma profunda transformação na legislação norte-americana cujos marcos foram a promulgação da lei dos direitos civis (Civil Rights Act), em 1964, e da lei dos direitos de voto (Voting Rights Act), em 1965. Mais do que isso, nesse contexto também surgiram as ações afirmativas propriamente ditas, que implicaram, para além do reconhecimento dos direitos civis de minorias e da proibição da segregação racial, a adoção de verdadeiras ações dirigidas à inclusão de minorias, tanto na esfera pública como na privada.

O próprio termo "ações afirmativas" foi cunhado ainda antes da década de 1960. O documento oficial que primeiro trouxe a expressão affirmative action foi a lei das relações de trabalho nacionais, de $1935^{185}$. Em que pese à existência desse exemplo, foi apenas a partir da década de 1960 que "[...] o termo passou a ser utilizado dentro de um contexto de luta pelos direitos civis [...]"186. Considera-se a célebre Executive Order $\mathrm{n}^{\mathbf{0}} 10.925$, de 1961, a primeira a trazer a expressão nesse contexto, mas ainda com uma conotação mais restrita $^{187}$, já que era entendida apenas como medida de combate à discriminação ${ }^{188}$. Essa Executive Order criou a Comissão para a Igualdade de Oportunidades de Emprego e objetivava a aplicação de medidas não-discriminatórias nas contratações efetuadas pelo Poder Executivo, exigindo-se que as contratadas se comprometessem a não discriminar seus empregados ou os aspirantes a emprego. Portanto, pode-se afirmar que essa Executive Order, embora trouxesse, em seu bojo, o termo affirmative action, não conferia “vantagens" ou "privilégios" a grupos minoritários, mas, ao contrário, exigia justamente o tratamento igualitário sem a consideração do pertencimento a algum desses grupos.

\footnotetext{
185 Cf. Sowell, Thomas. Affirmative Action Around the World: an Empirical Study. New Haven: Yale University Press, 2004, p. 123.

186 Kaufmann, Roberta Fragoso Menezes. Ações afirmativas à brasileira: necessidade ou mito? Porto Alegre: Livraria do Advogado, 2007, p. 169.

187 Cf. Menezes, Paulo Lucena de. Ação afirmativa (affirmative action) no direito norte-americano. São Paulo: Revista dos Tribunais, 2001, p. 88.

${ }^{188}$ Cf. Kaufmann, Roberta Fragoso Menezes. Ações afirmativas à brasileira: necessidade ou mito? Porto Alegre: Livraria do Advogado, 2007, p. 169.
} 
Em 1965, a Executive Order n ${ }^{\circ} 11.246$, a partir da qual criou-se o Office of Federal Contract Compliance no interior do Departamento do Trabalho, voltou a trazer o termo affirmative action ${ }^{189}$. Esse diploma determinou que o Poder Executivo dos Estados Unidos deveria condicionar a celebração de contratos com particulares à adoção de medidas nãodiscriminatórias. Esse diploma normativo possui relevante importância histórica, pois, segundo P. MENEZES, “[...] é a partir de seu surgimento que os programas voltados para o combate das desigualdades sociais com base em condutas positivas cresceram em importância e passaram a ser avaliados sob a ótica de políticas governamentais [...]"190. Contudo, embora possa ser considerado um divisor de águas no sentido acima exposto, esse documento ainda se situa na fase em que as ações afirmativas eram vistas como medidas de não-discriminação e não como verdadeiras políticas de inclusão, cabendo a conclusão de R. KAUFMANN:

\begin{abstract}
Como se observa dos textos das Ordens Executivas $n^{\circ} 10.925$ e 11.246 , os governos de Kennedy e Johnson não iniciaram as ações afirmativas conforme as entendemos hoje. Originalmente, o conceito de ação afirmativa significava uma política institucionalizada de combate à discriminação e não medidas de inclusão propriamente ditas. É que, à época, acreditava-se que o simples fato de o governo deixar de apoiar a discriminação [...] já sinalizava vultosos ganhos para a comunidade negra. ${ }^{191}$
\end{abstract}

Contemporânea da Executive Order n ${ }^{\circ} 11.246$, é de suma importância mencionar a adoção, no âmbito internacional, da Convenção Internacional sobre a Eliminação de Todas as Formas de Discriminação Racial, aberta a assinatura em 21 de dezembro de 1965. Esse tratado, ratificado pelo Brasil em 1968 e promulgado em $1969^{192}$, muito embora não traga explicitamente o termo ações afirmativas, autoriza "medidas especiais tomadas com o único objetivo de assegurar progresso adequado de certos grupos raciais ou étnicos". Nesse

\footnotetext{
189 " [...] The contractor will take affirmative action to ensure that applicants are employed, and that employees are treated during employment, without regard to their race, color, religion, sex or national origin. Such action shall include, but not be limited to the following: employment, upgrading, demotion, or transfer; recruitment or recruitment advertising; layoff or termination; rates of pay or other forms of compensation; and selection for training, including apprenticeship. [...]" Executive Order 11246. Disponível em: $<\mathrm{http} / / /$ www.archives.gov/federal-register/codification/executive-order/11246.html $>$. Acesso em: $17 \mathrm{de}$ dezembro de 2009.

${ }^{190}$ Menezes, Paulo Lucena de. Ação afirmativa (affirmative action) no direito norte-americano. São Paulo: Revista dos Tribunais, 2001, p. 92.

${ }^{191}$ Kaufmann, Roberta Fragoso Menezes. Ações afirmativas à brasileira: necessidade ou mito? Porto Alegre: Livraria do Advogado, 2007, p. 171.

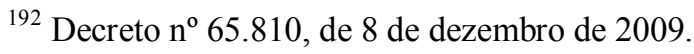


caso, é possível observar a influência exercida pelo debate sobre as nascentes políticas de ação afirmativa nos Estados Unidos que, ainda na década de 1960, extrapolou as fronteiras daquele Estado, firmando-se inclusive no âmbito do Direito Internacional dos Direitos Humanos.

A "fase áurea" das ações afirmativas nos Estados Unidos ocorreu na década de 1970. Diante de uma série de conflitos e motins aliados a um relativo fracasso das políticas exclusivamente não-discriminatórias, fermentaram nas próprias camadas políticas dominantes propostas de concessão de "vantagens" ou "privilégios" às minorias étnicas e, posteriormente, às mulheres - de modo a facilitar-lhes o acesso ao emprego e à educação, notoriamente. Nessa década, “[...] eclodiram ações afirmativas no âmbito estadual, municipal, em empresas privadas, no comércio, no sistema educacional e em associações." ${ }^{193}$ Nesse período surgiram diversos planos que determinavam metas ${ }^{194}$ a serem atingidas, em determinado espaço de tempo (timetables), no que diz respeito à integração das minorias, como explica J. KelloUGH:

[...] numerical goals and timetables for minority employment began to appear in affirmative action plans in the late 1960s and early in the 1970s. Later, they also were developed to assist women. Numerical goals are targets for the representation of minorities and women in an organization. Timetables set dates or timeframes within which goals are scheduled to be accomplished. [...]

The impetus for development of affirmative action goals and timetables was the excruciatingly slow rate of progress made by minorities and women under earlier approaches and the perception by many observers that the problem was grave enough that an alternative strategy was necessary. ${ }^{195}$

No interior do Poder Executivo norte-americano, o Office of Federal Contract Compliance, ainda a partir de 1968, emitiu diretrizes destinadas às empresas contratadas pelo governo federal nas quais determinava metas a serem cumpridas quanto à representação das diferentes minorias nos quadros de empregados. T. SOWELL afirma que foram as diretrizes emitidas em dezembro de 1971 que imprimiram um "conceito numérico" às ações afirmativas, seja por "metas", seja por "quotas":

193 KaUfmanN, Roberta Fragoso Menezes. Ações afirmativas à brasileira: necessidade ou mito? Porto Alegre: Livraria do Advogado, 2007, p. 177.

${ }^{194}$ O sistema de metas (goals) é uma das possíveis modalidades de ação afirmativa, sendo diferente, por exemplo, do sistema de quotas. Cf. Menezes, Paulo Lucena de. Ação afirmativa (affirmative action) no direito norte-americano. São Paulo: Revista dos Tribunais, 2001, p. 31-32.

195 Kellough, J. Edward. Understanding Affirmative Action: politics, discrimination and the search for justice. Washington: Georgetown University Press, 2006, p. 7. 
In May 1968, this office [Office of Federal Contract Compliance in the U.S. Department of Labor] issued guidelines containing the fateful expression 'goals and timetables' and 'representation.' But as yet these were still not quotas, for 1968 guidelines spoke of 'goals and timetables for the prompt achievement of full and equal employment opportunity.' [...] In December 1971 the decisive guidelines were issued, which made it clear that 'goals and timetables' were meant to 'increase materially the utilization of minorities and women' $[\ldots]$ 'Affirmative action' was now decisively transformed into a numerical concept, whether called 'goals' or 'quotas.' Affirmative action in this specific sense was thus a product of the decade of the 1970s..$^{196}$

É importante ressaltar, portanto, que, em sua origem, as ações afirmativas estavam especialmente ligadas aos problemas enfrentados pelas minorias étnicas no acesso ao mercado de trabalho e à educação nos Estados Unidos, como ilustra J. GOMES:

\begin{abstract}
Inicialmente, as Ações Afirmativas se definiam como um mero "encorajamento" por parte do Estado a que as pessoas com poder decisório nas áreas públicas e privada levassem em consideração, nas suas decisões relativas a temas sensíveis como o acesso à educação e ao mercado de trabalho, fatores até então tidos como formalmente irrelevantes pela grande maioria dos responsáveis políticos e empresariais, quais sejam, a raça, a cor, o sexo e a origem nacional das pessoas. Tal encorajamento tinha por meta, tanto quanto possível, ver concretizado o ideal de que tanto as escolas quanto as empresas refletissem em sua composição a representação de cada grupo na sociedade ou no respectivo mercado de trabalho. ${ }^{197}$
\end{abstract}

Contudo, também há de ser ressaltado que, na sua gênese, as ações afirmativas foram medidas tomadas ou encorajadas pelo próprio Estado norte-americano, então dominado por uma elite conservadora, com o claro propósito de abrandar as revoltas e os motins levados a cabo por grupos ligados ao movimento negro, principalmente após o assassinato de Martin Luther King em 1968, que criaram “[...] um ambiente destrutivo totalmente desconhecido para a maioria dos americanos brancos." ${ }^{198}$ Muitos desses, por sua vez, organizavam-se em grupos e sociedades que, não raro, utilizavam métodos violentos e cruéis contra a ascensão social e econômica dos negros. Criava-se, assim, um clima de enfrentamento e violência, atingindo tal proporção que os contemporâneos

196 Sowell, Thomas. Affirmative Action Around the World: an Empirical Study. New Haven: Yale University Press, 2004, p. 124-125.

${ }^{197}$ Gomes, Joaquim B. Barbosa. Ação afirmativa \& princípio constitucional da igualdade. Rio de Janeiro: Renovar, 2001, p. 39.

${ }^{198}$ Kaufmann, Roberta Fragoso Menezes. Ações afirmativas à brasileira: necessidade ou mito? Porto Alegre: Livraria do Advogado, 2007, p. 174. 
inclusive temiam o advento de uma "segunda guerra civil norte-americana". O Estado, embora dominado por sua tradicional elite conservadora, não poderia permitir a intensificação desses conflitos: tomando medidas destinadas a aplacar a inquietação social para além das medidas não-discriminatórias, começou a promover as ações afirmativas, agora sim entendidas como verdadeiras políticas de inclusão social das minorias.

Para a consolidação das ações afirmativas teve grande relevância a atuação do Poder Judiciário dos Estados Unidos - com destaque para a suprema corte - nas décadas de 1970 e 1980, a dar grande ênfase na aplicação da igualdade e produzindo farta jurisprudência a respeito do tema. Trata-se do viés judiciário das ações afirmativas: P. MENEZES afirma que “[...] é incontestável que a Suprema Corte teve uma influência fundamental na formatação do perfil dessas políticas ao definir, ela própria, diretrizes e paradigmas que foram seguidos por toda a sociedade." ${ }^{199}$. Nesse sentido, $\mathrm{S}$. ATCHABAHIAN:

\begin{abstract}
Assim, considerando que a ação afirmativa nasceu na década de 60 e teve pujança nos Estados Unidos nas décadas de 70 e 80, ela deve também a sua existência, em grande medida, à atuação da Suprema Corte desse país.

Essa Corte norte-americana desempenhou um papel muito importante no tocante aos direitos humanos, à grande responsabilidade que ponderava ao refazer o conteúdo dos direitos fundamentais, especialmente, no relacionado ao princípio jurídico de igualdade, especificamente no período que se seguiu a Segunda Grande Guerra. ${ }^{200}$
\end{abstract}

O Poder Judiciário norte-americano, nessa época, além de chancelar inúmeras políticas de ação afirmativa que surgiam por iniciativa principalmente do Poder Executivo, em muitos casos chegou, inclusive, a subverter o sentido das disposições legais antidiscriminatórias ao admitir diferenciações fundamentadas na raça, sexo, entre outros fatores. O caso Griggs v. Duke Power Company, julgado em 1971 pela suprema corte norte-americana, foi um exemplo da aplicação "subvertida" do Civil Rights Act de 1964. Nesse caso ficou decidido que testes de aptidão ou outros procedimentos, apesar de serem "neutros" na aparência ou na intenção dos aplicadores, não seriam considerados válidos se causassem um impacto desproporcional (disparate impact) relativamente a determinados grupos e não fossem devidamente justificados pelo aplicador, que teria, assim, o ônus de

${ }^{199}$ MenEZES, Paulo Lucena de. Ação afirmativa (affirmative action) no direito norte-americano. São Paulo: Revista dos Tribunais, 2001, p. 33.

${ }^{200}$ AtChABAHIAN, Serge. Principio da igualdade e ações afirmativas. São Paulo: RCS, 2004, p. 149. 
provar a adequação do procedimento ou teste ${ }^{201}$. Dada a dificuldade de produzir a prova necessária à "validação" dos testes e procedimentos que provocassem impacto desproporcional, a decisão significou, na prática, a impossibilidade de submissão de empregados a testes ou exames de aptidão, contrariando determinação legal expressa na própria Civil Rights Act de 1964. Assim, "[t]he Griggs decision was not the only example of courts reading the Civil Rights Act of 1964 to mean precisely what the Act and its legislative history had clearly said that it did not mean.",202

Outro exemplo pode ser encontrado no caso United Steelworkers of America $v$. Weber, julgado em 1979. Nesse caso, Brian Weber, funcionário branco de uma empresa química e metalúrgica da Louisiana, alegou que o programa de ação afirmativa adotado pela empresa, que reservava aos empregados negros uma quota de 50\% das vagas no seu programa de treinamento, causou-lhe discriminação reversa, já que fora preterido em favor de empregados negros com menos tempo de serviço. Weber fundamentou seu pedido na seção 703 (a) da Civil Rights Act de $1964^{203}$ que, em suma, proíbe a discriminação de empregados com base, entre outros critérios, na cor ou raça. A despeito da linguagem clara desse diploma normativo, a suprema corte norte-americana rejeitou o pedido de Weber, pelos seguintes argumentos, expostos por T. SOWELL:

Writing for the majority, Justice William J. Brennan rejected 'a literal interpretation of these words.' He claimed that the 'spirit' of the Act had as its 'primary concern' the economic problems of blacks, so that it did not bar

\footnotetext{
${ }^{201}$ A teoria do impacto desproporcional foi uma autêntica construção jurisprudencial da suprema corte norteamericana, inicialmente no campo do Direito do Trabalho - embora sua aplicação tenha posteriormente se expandido a outras áreas. Essa teoria entende que não é válida a aplicação de determinado critério aparentemente neutro que gere incidência desproporcional entre categorias de pessoas, mesmo que a discriminação não seja implícita, intencional ou mesmo tenha sido o objetivo na adoção do referido critério. Cf. Gomes, Joaquim B. Barbosa. Ação afirmativa \& princípio constitucional da igualdade. Rio de Janeiro: Renovar, 2001, p. 24; Sowell, Thomas. Affirmative Action Around the World: an Empirical Study. New Haven: Yale University Press, 2004, p. 129-130 e MENEZES, Paulo Lucena de. Ação afirmativa (affirmative action) no direito norte-americano. São Paulo: Revista dos Tribunais, 2001, p. 96.

202 Sowell, Thomas. Affirmative Action Around the World: an Empirical Study. New Haven: Yale University Press, 2004, p. 126-127.

203 'Sec. 703. (a) It shall be an unlawful employment practice for an employer - (1) to fail or refuse to hire or to discharge any individual, or otherwise to discriminate against any individual with respect to his compensation, terms, conditions, or privileges of employment, because of such individual's race, color, religion, sex, or national origin; or (2) to limit, segregate, or classify his employees in any way which would deprive or tend to deprive any individual of employment opportunities or otherwise adversely affect his status as an employee, because of such individual's race, color, religion, sex or national origin." Civil Rights Act of 1964. Disponível em: <http://www.archives.gov/education/lessons/civil-rights-act/images/act-05.jpg $>$. Acesso em: 18 de dezembro de 2009.
} 
'temporary, voluntary, affirmative action undertaken to eliminate manifest racial imbalance in traditionally segregated job categories. ${ }^{204}$

É curioso notar que, no ano anterior (1978), a suprema corte norte-americana julgara o célebre caso Regents of the University of California v. Bakke, em que decidiu uma ação proposta por um aspirante branco a uma vaga no curso de medicina da Universidade da Califórnia que, embora tenha obtido notas suficientes à admissão, teve sua matrícula rejeitada porque a universidade reservava dezesseis vagas (de um universo de cem vagas) para membros de grupos minoritários e/ou em condições econômicas ou educacionais desvantajosas. A decisão, conquanto tenha considerado válidas as políticas de ação afirmativa - inclusive as que se utilizassem, sob certas circunstâncias, de critérios etnicorraciais $^{205}$-, concluiu que quotas ou metas rígidas e inflexíveis atentariam contra a igual proteção da lei (equal protection clause) prevista na $14^{\mathrm{a}}$ emenda à Constituição dos Estados Unidos.

Neste ponto já é possível detectar certas incongruências no padrão decisório da suprema corte norte-americana: no caso Regents of the University of California v. Bakke, por exemplo, considerou-se inválida a aplicação de quotas e metas fixas, ao passo que, no caso United Steelworkers of America v. Weber, elas foram consideradas válidas. Os casos aqui trazidos à análise não foram escolhidos aleatoriamente: ao contrário, foram trazidos justamente porque permitem, de modo claro, visualizar o padrão "ziguezague" das decisões da suprema corte norte-americana, ao longo dos anos, a respeito do tema das ações afirmativas $^{206}$. Deixando-se de lado alguns meandros que justificam essas decisões incongruentes entre $\mathrm{si}^{207}$, o importante é ter-se ciência de que a suprema corte norte-

${ }^{204}$ Sowell, Thomas. Affirmative Action Around the World: an Empirical Study. New Haven: Yale University Press, 2004, p. 127.

${ }^{205}$ Cf. Dworkin, Ronald. Uma questão de principio. Tradução Luís Carlos Borges. São Paulo: Martins Fontes, 2000, p. 455.

${ }^{206}$ Cf. Sowell, Thomas. Affirmative Action Around the World: an Empirical Study. New Haven: Yale University Press, 2004, p. 128.

207 "Em se tratando de ações afirmativas, múltiplas questões foram abordadas; argumentos ora rechaçados em uns casos, foram considerados válidos em outros, as decisões variaram, muitas vezes, a depender de cuja autoridade emanara o programa afirmativo, se de empresa privada, de universidade, de lei oriunda do Congresso ou de medidas regionais." KAUFMANN, Roberta Fragoso Menezes. Ações afirmativas à brasileira: necessidade ou mito? Porto Alegre: Livraria do Advogado, 2007, p. 182. Ademais, havia grandes divergências entre os próprios integrantes da suprema corte norte-americana, que ora conseguiam tornar suas teses as vencedoras, mas ora as viam derrotadas. 
americana "[...] não conseguiu desenvolver uma linha de raciocínio uniforme nos diversos julgamentos" ${ }^{208}$, como ilustra P. MENEZES, remetendo a M. ROSENFELD:

De Regents of the University of California v. Bakke até 1990, a Suprema Corte julgou pelo menos dez importantes processos versando sobre ação afirmativa. No entanto, como aponta Rosenfeld, o aspecto mais marcante de todas estas decisões, quando analisadas em conjunto, é a constatação de que o referido Tribunal não conseguiu definir, com clareza e autoridade, os exatos limites da ação afirmativa. ${ }^{209}$

Não obstante, a despeito do inegável padrão "ziguezague", seria incorreto deduzir que não houve valiosas contribuições da suprema corte norte-americana para o delineamento das ações afirmativas. Primeiramente, porque houve consenso em alguns aspectos: no campo das relações de trabalho, por exemplo, P. MENEZES identificou alguns critérios efetivamente criados pelo tribunal, como a impossibilidade da aplicação das ações afirmativas para manter um equilíbrio entre grupos minoritários (mas apenas para eliminar um desequilíbrio evidente) e a temporariedade dessas medidas ${ }^{210}$. Segundo, porque foi possível observar, com o passar dos anos, algumas tendências, como a expansão do conceito de discriminação, que passou a envolver outros grupos tidos por "minoritários". Nesse sentido, T. SOWELL:

Despite a zig-zag pattern of judicial decisions over the years, the general trend
has been toward ever more expansive definitions of "discrimination," leading to
more and more "remedial" group preferences and quotas.

Como afirma J. GoMES ${ }^{212}$, embora repletas de ambiguidades, é possível dividir a atuação da suprema corte norte-americana em três fases mais ou menos distintas. A primeira fase (década de 1970) foi marcada pela indecisão do tribunal quanto à validade das ações afirmativas, suas características e seus limites: nessa fase o "ziguezague" foi

\footnotetext{
208 KaUfmanN, Roberta Fragoso Menezes. Ações afirmativas à brasileira: necessidade ou mito? Porto Alegre: Livraria do Advogado, 2007, p. 182.

${ }^{209}$ Menezes, Paulo Lucena de. Ação afirmativa (affirmative action) no direito norte-americano. São Paulo: Revista dos Tribunais, 2001, p. 107.

${ }^{210}$ MENEZES, Paulo Lucena de. Ação afirmativa (affirmative action) no direito norte-americano. São Paulo: Revista dos Tribunais, 2001, p. 110.

211 Sowell, Thomas. Affirmative Action Around the World: an Empirical Study. New Haven: Yale University Press, 2004, p. 128.

212 Cf. Gomes, Joaquim B. Barbosa. Ação afirmativa \& princípio constitucional da igualdade. Rio de Janeiro: Renovar, 2001, p. 238.
} 
mais pronunciado. A segunda fase (década de 1980) foi marcada pela posição de aprovação do tribunal às medidas de ação afirmativa. Por fim, a terceira fase foi marcada pela tendência da suprema corte norte-americana, perceptível após um momento expansivo do âmbito de aplicação das ações afirmativas, à gradativa restrição desse gênero de medidas a partir do final da década de 1980. Durante o período de seu mandato, o presidente Ronald Reagan, opositor das políticas de ação afirmativa, conseguiu mudar o perfil ideológico não apenas dos membros das instâncias inferiores, mas também da própria suprema corte:

Como a reviravolta na orientação jurisprudencial da Corte vem demonstrando nos últimos dez anos, os profissionais agraciados com essas nomeações foram rigorosamente escolhidos em função de suas tomadas de posição ostensivamente contrárias às ações afirmativas. Por trás dos argumentos técnicos e não raro bizantinos de muitas das decisões objeto de análise ao longo deste estudo, encontra-se, sem sombra de dúvidas, essa clivagem ideológica provocada pela Era Reagan. $^{213}$

No caso Wards Cove Packing Co. v. Antonio (1989), por exemplo, afastou-se o entendimento firmado no caso Griggs v. Duke Power Company, de modo que o ônus da prova da discriminação por impacto desproporcional deveria recair sobre o empregado. Outro julgado que merece menção foi o proferido no caso Adarand Constructor, Inc. v. Pena (1995), pelo qual se estendeu o padrão rigoroso de análise (strict scrutiny) a todos os casos de ação afirmativa que envolvessem os Estados e a União ${ }^{214}$. A adoção do padrão rigoroso de análise significou, na prática, a assemelhação, para fins de análise jurisdicional da suprema corte norte-americana, entre as distinções "benéficas" baseadas em critérios como gênero e raça - as medidas de ação afirmativa - e as distinções "maléficas" discriminações. Tornou-se, assim, consideravelmente mais difícil demonstrar em juízo a constitucionalidade das políticas de ação afirmativa, já que, pelo strict scrutiny, presume-se que o fator de diferenciação é inconstitucional, cabendo ao aplicador do critério demonstrar que essas medidas são as menos restritivas possíveis (narrowly tailored

\footnotetext{
${ }^{213}$ Gomes, Joaquim B. Barbosa. Ação afirmativa \& princípio constitucional da igualdade. Rio de Janeiro: Renovar, 2001, p. 228-229.

${ }^{214}$ Cf. Kellough, J. Edward. Understanding Affirmative Action: politics, discrimination and the search for justice. Washington: Georgetown University Press, 2006, p. 111.
} 
measures) entre as destinadas a fomentar interesses estatais cogentes (compelling governmental interests) ${ }^{215}$.

Paralelamente aos recentes entendimentos jurisprudenciais, o plano legislativo norte-americano também parece caminhar para uma maior restrição às políticas de ação afirmativa. Nesse ponto, um marco foi a aprovação, por plebiscito realizado em 1996, da Proposition 209, com 54\% de aprovação pelo eleitorado do Estado da Califórnia. Essa lei proíbe que o Estado da Califórnia discrimine qualquer indivíduo ou a ele dê tratamento preferencial em razão da raça, sexo, origem nacional, etc., nas relações de emprego público, contratação pública ou educação pública, virtualmente encerrando a possibilidade de aplicação de medidas de ação afirmativa pelo governo de um dos Estados pioneiros nesse gênero de política de inclusão. Apesar de a Proposition 209 ser aplicável apenas à administração estadual - não abrangendo, portanto, o âmbito de atuação da União ou de pessoas de direito privado -, essa lei serviu de inspiração a muitas propostas apresentadas a órgãos legislativos de diversos Estados e municípios $^{216}$. J. SKRENTNY noticia que, em 2006, uma medida semelhante foi aprovada por $58 \%$ do eleitorado do Estado de Michigan ${ }^{217}$.

Por essas razões, muitos já falam de um declínio da ação afirmativa norteamericana. Há inúmeros movimentos e propostas destinados a reduzir a amplitude das ações afirmativas nos Estados Unidos. Contudo, declínio não significa fim: “[...] é pouco provável que ocorra num futuro próximo o total desmantelamento dos programas de ação afirmativa."218 Ainda há grande apoio da sociedade às ações afirmativas, independentemente da posição política dos indivíduos ${ }^{219}$ e um veemente apoio à extinção desse gênero de medidas por um partido pode significar um suicídio político. Ademais, na

215 Cf. MenEzes, Paulo Lucena de. Ação afirmativa (affirmative action) no direito norte-americano. São Paulo: Revista dos Tribunais, 2001, p. 61-62 e Kellough, J. Edward. Understanding Affirmative Action: politics, discrimination and the search for justice. Washington: Georgetown University Press, 2006, p. 129.

216 Cf. Menezes, Paulo Lucena de. Ação afirmativa (affirmative action) no direito norte-americano. São Paulo: Revista dos Tribunais, 2001, p. 144.

${ }^{217}$ Cf. SKrentny, John. L' “affirmative action” américaine en déclin. Le Monde diplomatique, Paris, a. 54, n. 638, mai 2007, p. 14.

218 Gomes, Joaquim B. Barbosa. Ação afirmativa \& princípio constitucional da igualdade. Rio de Janeiro: Renovar, 2001, p. 230.

${ }^{219}$ Cf. JONES, Jeffrey M. Race, Ideology and Support for Affirmative Action. [S.1.]: Gallup, 2005. Disponível em: <http:/www.gallup.com/poll/18091/race-ideology-support-affirmative-action.aspx>. Acesso em 22 de dezembro de 2009. 
suprema corte dos Estados Unidos, em que pese a sua posição cada vez mais restritiva, as medidas de ação afirmativa nunca foram consideradas inconstitucionais em si e por si:

\begin{abstract}
Note-se, contudo, que a perspectiva de um total loteamento da Corte por juízes de orientação política conservadora poderá não significar necessariamente a retirada das ações afirmativas da paisagem jurídica americana, uma vez que, nos trinta anos de existência desses programas, jamais a Corte Suprema, nem mesmo sob o controle da atual maioria conservadora, considerou inconstitucional o princípio em si das medidas, isto é, o uso de fatores como raça e gênero como critério na elaboração de políticas públicas tendentes a avançar os direitos de minorias socialmente fragilizadas. ${ }^{20}$
\end{abstract}

As ações afirmativas, de sua origem na Índia e de seu desenvolvimento nos Estados Unidos, vivenciaram uma forte força expansiva. Como já mencionado, desde a década de 1960 há autorização para a adoção desse gênero de política de inclusão na esfera do Direito Internacional dos Direitos Humanos. Mas a força expansiva das ações afirmativas não parou por aí: inúmeros países, inspirados pelo exemplo norte-americano, adotaram medidas de ação afirmativa mesmo sem autorização constitucional ou legal expressas. Outros países foram além, as autorizando expressamente em suas próprias constituições, seguindo o exemplo indiano. Ao mesmo tempo em que os Estados Unidos começaram a, paulatinamente, restringir as políticas de ação afirmativa, observou-se uma grande ampliação desse gênero de medidas ao redor do mundo.

Além da pioneira Índia, outro país que se destaca pela permissão constitucional expressa às medidas de ação afirmativa é o Canadá, cuja experiência em matéria de ação afirmativa foi reconhecidamente influenciada pelo modelo norte-americano ${ }^{221}$. Em 1982 foi introduzido o Charter of Rights, veiculado pela Constitution Act de 1982, que assevera, em seu art. 15 (1), que todo indivíduo é "[...] equal before and under the law and has the right to the equal protection and equal benefit of the law without discrimination [...]", mas ressalva, no seu art. 15 (2), a possibilidade de se adotar medidas de ação afirmativa:

\author{
15. [...] \\ Affirmative action programs \\ Subsection (1) does not preclude any law, program or activity that has as its \\ object the amelioration of conditions of disadvantaged individuals or groups
}

\footnotetext{
${ }^{220}$ Gomes, Joaquim B. Barbosa. Ação afirmativa \& princípio constitucional da igualdade. Rio de Janeiro: Renovar, 2001, p. 231.

${ }^{221}$ Cf. Menezes, Paulo Lucena de. Ação afirmativa (affirmative action) no direito norte-americano. São Paulo: Revista dos Tribunais, 2001, p.128.
} 
including those that are disadvantaged because of race, national or ethnic origin, colour, religion, sex, age or mental or physical disability. ${ }^{222}$

Mais recentemente, o fim do apartheid na África do Sul e a independência da Namíbia trouxeram novas experiências quanto à permissão constitucional expressa para a adoção de programas de ação afirmativa. Independente da África do Sul desde 1990, a República da Namíbia adotou sua constituição no mesmo ano. Esse diploma prevê a igualdade perante a lei (art 10.1), proíbe a discriminação em razão da raça, cor, religião, condição econômica, etc. (art. 10.2), prevê a criminalização da discriminação racial e da apologia ao apartheid (art. 23.1) e, inovadoramente, autoriza a adoção de medidas destinadas a promover o avanço de pessoas em desvantagem, inclusive prevendo um balanceamento na estrutura do serviço público e reconhecendo a discriminação especial sofrida pelas mulheres (art. 23.2 e 23.3):

Article 23 Apartheid and affirmative action [...]

(2) Nothing contained in Article 10 hereof shall prevent Parliament from enacting legislation providing directly or indirectly for the advancement of persons within Namibia who have been socially, economically or educationally disadvantaged by past discriminatory laws or practices, or for the implementation of policies and programmes aimed at redressing social, economic or educational imbalances in the Namibian society arising out of past discriminatory laws or practices, or for achieving a balanced structuring of the public service, the police force, the defence force, and the prison service.

(3) In the enactment of legislation and the application of any policies and practices contemplated by Sub-Article (2) hereof, it shall be permissible to have regard to the fact that women in Namibia have traditionally suffered special discrimination and that they need to be encouraged and enabled to play a full, equal and effective role in the political, social, economic and cultural life of the nation. ${ }^{223}$

Seguindo a esteira da Constituição da Namíbia, a Constituição da África do Sul pós-apartheid de 1996, além de prever a igualdade perante a lei (art. 9.1), autoriza medidas destinadas a proteger ou promover pessoas, ou categorias de pessoas em desvantagem devido a discriminações injustas (art. 9.2). É de se notar que a Constituição sul-africana não proíbe a "discriminação", mas a "discriminação injusta", baseada em um dos critérios trazidos pelo vasto rol do art. 9.3, estabelecendo, ainda, que as "discriminações" baseadas

${ }^{222}$ Constitution Act, 1982. Disponível em: <http://laws.justice.gc.ca/en/const/9.html\#anchorsc:7>. Acesso em: 21 de dezembro de 2009.

223 The Constitution of the Republic of Namibia. Disponível em: $<$ http://www.lac.org.na/laws/pdf/namcon.pdf $>$. Acesso em: 22 de dezembro de 2009. 
em um ou mais desses critérios é presumidamente injusta exceto se for "estabelecido que a discriminação é justa" (art. 9.5):

9. Equality [...]

(3) The state may not unfairly discriminate directly or indirectly against anyone on one or more grounds, including race, gender, sex, pregnancy, marital status, ethnic or social origin, colour, sexual orientation, age, disability, religion, conscience, belief, culture, language and birth.

(4) No person may unfairly discriminate directly or indirectly against anyone on one or more grounds in terms of subsection (3). National legislation must be enacted to prevent or prohibit unfair discrimination.

(5) Discrimination on one or more of the grounds listed in subsection (3) is unfair unless it is established that the discrimination is fair. ${ }^{224}$

Os casos da Namíbia e da África do Sul são basilares para se entender a expansão do conceito de grupos minoritários - entendidos como os grupos em desvantagem aos quais as políticas de ação afirmativa são dirigidas. Com efeito, em sua origem, nos Estados Unidos, as medidas de ação afirmativa eram destinadas a grupos quantitativamente minoritários: os negros norte-americanos. Contudo, com a expansão da noção de discriminação veio a própria expansão do conceito de minorias, que passou, mesmo nos Estados Unidos, a designar grupos quantitativamente majoritários, como as mulheres. Uma nova definição de grupos minoritários tornou-se necessária, tema que será abordado na próxima seção.

Seguindo o exemplo dos Estados Unidos, muitos países, mesmo sem a autorização constitucional expressa, vêm adotando, em maior ou menor grau, políticas de ação afirmativa. O debate sobre as políticas de ação afirmativa está presente até mesmo na França, o berço europeu da égalité devant la loi e país tradicionalmente adverso a medidas ditas "discriminatórias", ainda que "positivas". O próprio termo utilizado na França para designar as ações afirmativas - discrimination positive - traz certa carga semântica negativa, pois dá a entender que os programas em questão são baseados em uma discriminação. M. BOSSUYT critica essa denominação: para ele, discriminação positiva é uma contradictio in terminis, já que discriminação é sempre negativa. Ou seja, discriminação é a distinção injusta, ilegítima, arbitrária - proibida, portanto -, podendo haver distinções justas, legítimas e racionais - logo, permitidas -, como no caso das ações

\footnotetext{
224 Constitution of the Republic of South Africa. Disponível em: $<$ http://www.info.gov.za/documents/constitution/1996/a108-96.pdf>. Acesso em: 22 de dezembro de 2009.
} 
afirmativas $^{225}$. Na França, contudo, em 1987, foi aprovada uma lei que impõe uma quota de $6 \%$ dos postos de trabalho no serviço público a ser destinada a deficientes ${ }^{226}$ e, em 1999, uma revisão constitucional determinou que "[1]a loi favorise l'égal accès des femmes et des hommes aux mandats électoraux et fonctions électives, ainsi qu'aux responsabilités professionnelles et sociales" ${ }^{, 27}$, dispositivo que pode servir de base a futuras medidas de ação afirmativa baseadas no gênero. Quanto a políticas de ação afirmativa baseadas em critérios etnicorraciais, a questão é muito mais complexa, pois começa na própria ausência de dados e estatísticas que possibilitem quantificar e qualificar os efeitos da discriminação etnicorracial. O próprio conselho constitucional francês invalidou, em 2007, uma lei que autorizava a coleta de dados referentes à raça e à etnia ${ }^{228}$. D. OPPENHEIMER explica:

[...] in France, where a central principle of republicanism is that the only legitimate identity in the public sphere is citizenship, it is unacceptable for a state agent to ask a person for her race or ethnicity $[\ldots]$ it is central to the French ideal of equality and citizenship that the state refrain from making distinctions based on race or ethnicity $[\ldots]$ The French state is therefore generally barred from collecting data that we regard as commonplace in the United States. ${ }^{229}$

O Brasil também sofreu os efeitos da força expansiva das ações afirmativas. $O$ constituinte de 1987 já demonstrou sua preocupação com a inclusão social de minorias, o que se reflete em dispositivos contidos na CF. Embora não contenha uma autorização genérica explícita para a adoção de políticas de ação afirmativa, a exemplo da Índia ou da África do Sul, a CF trouxe dispositivos específicos que merecem atenção: a gratuidade da assistência jurídica a quem comprovar insuficiência de recursos (art. 5 ${ }^{\circ}$, LXXIV), a

${ }^{225}$ Cf. BossuYt, Marc. Prevention of discrimination: the concept and practice of affirmative action. Relatório final apresentado à comissão de Direitos Humanos do Conselho Econômico e Social das Nações Unidas. New York: ECOSOC, 2002, p. 2-3.

${ }^{226}$ VIDAL, Dominique. Um faux débat à la française. Le Monde diplomatique, Paris, a. 54, n. 638, mai 2007, p. 15.

227 Constitution de la République Française. Disponível em: <http://www.assembleenationale.fr/connaissance/constitution_1209.pdf $>$. Acesso em: 22 de dezembro de 2009.

228 “[... 29. Considérant que, si les traitements nécessaires à la conduite d'études sur la mesure de la diversité des origines des personnes, de la discrimination et de l'intégration peuvent porter sur des données objectives, ils ne sauraient, sans méconnaître le principe énoncé par l'article 1er de la Constitution, reposer sur l'origine

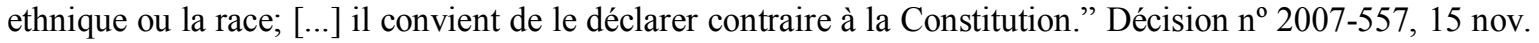
2007. Disponível em : <http://www.conseil-constitutionnel.fr/conseil-constitutionnel/francais/lesdecisions/acces-par-date/decisions-depuis-1959/2007/2007-557-dc/decision-n-2007-557-dc-du-15-novembre2007.1183.html>. Acesso em: 22 de dezembro de 2009.

229 OpPenheIMER, David Benjamin. Why France Needs to Collect Data on Racial Identity... In a French Way. Hastings International and Comparative Law Review, San Francisco, v. 31, Summer 2008, p. 736-737. 
gratuidade do registro civil de nascimento e da certidão de óbito para os reconhecidamente pobres (art. $5^{\circ}, \mathrm{LXXVI)}$, a proteção do mercado de trabalho da mulher mediante incentivos específicos (art. $7^{\circ}, \mathrm{XX}$ ), a reserva de cargos e empregos públicos para as pessoas portadoras de deficiência (art. 37, VIII) e o tratamento favorecido às empresas de pequeno porte (art. 170, IX). Todos os dispositivos citados não apenas autorizam, mas determinam que sejam efetuadas distinções com base no gênero, na integridade física ou na capacidade econômica.

Posteriormente à promulgação da $\mathrm{CF}$, o debate sobre as ações afirmativas no Brasil passou a assumir maior relevo sobretudo em razão de demandas oriundas dos movimentos negros brasileiros. Em 1995, tricentenário da morte de Zumbi dos Palmares, entidades do movimento negro promoveram uma marcha em Brasília cuja pauta de reivindicações incluía medidas de ação afirmativa em benefício desse segmento etnicorracial ${ }^{230}$. Em 2001, por ocasião dos preparativos para a $3^{\text {a }}$ Conferência Mundial contra o Racismo, a Discriminação Racial, a Xenofobia e a Intolerância Correlata realizada em Durban, o debate sobre as ações afirmativas passou a ser veiculado na grande mídia. Nessa ocasião, órgãos de pesquisas oficiais como o IBGE e o IPEA divulgaram dados que revelavam a profunda disparidade de indicadores socioeconômicos entre brancos e negros no Brasil, impulsionando uma “[...] mudança de rumo nas políticas públicas [...]”231 . Em consonância com o relatório e plano de ação da conferência, o Poder Executivo passou a propor algumas medidas de ação afirmativa ${ }^{232}$.

Assim, o plano infraconstitucional tornou-se ainda mais amplo que o constitucional no que tange às ações afirmativas. No caso do acesso ao ensino superior público, a Medida Provisória $n^{\circ} 213 / 04$ (convertida em lei no ano seguinte) ${ }^{233}$, que criou o ProUni, instituiu medida de ação afirmativa na medida em que determina que, em troca de incentivos fiscais, instituições de ensino superior privadas reservem vagas a serem destinadas, mediante bolsa integral ou parcial, a estudantes que demonstrarem insuficiência de

${ }^{230}$ Cf. MunANGA, Kabengele. Os descendentes de africanos escravizados no Brasil na atualidade: realidades e problemas. Trabalho apresentado à International Conference on the Siddis of India and the African Diasporas in Asia, 2006, Goa.

${ }^{231}$ CARVALHO, José Jorge de. Inclusão Étnica e Racial no Brasil: a questão das cotas no ensino superior. São Paulo: Attar, 2005, p. 44.

${ }^{232} \mathrm{Cf}$. MunANGA, Kabengele. Os descendentes de africanos escravizados no Brasil na atualidade: realidades e problemas. Trabalho apresentado à International Conference on the Siddis of India and the African Diasporas in Asia, 2006, Goa.

${ }^{233}$ Lei $^{\circ} 11.096 / 05$. 
recursos e sejam egressos do ensino público, bolsistas do ensino privado ou portadores de deficiência (entre estes estudantes, há previsão de reserva de vagas a quem se declarar negro ou indígena) ${ }^{234}$. No Estado do Rio de Janeiro, a Lei Estadual n ${ }^{\circ}$ 4.151/03, estabeleceu um sistema de quotas para o acesso de minorias ao ensino oferecido pelas universidades estaduais, apesar de ter sua constitucionalidade impugnada no STF ${ }^{235}$. Mesmo diante da ausência de lei autorizante específica, pelo menos oitenta e uma instituições públicas de ensino superior, no exercício de suas atribuições administrativas, estabeleceram alguma medida de ação afirmativa destinada a fomentar o acesso de minorias a seus quadros discentes ${ }^{236}$. Embora o debate sobre as ações afirmativas no Brasil se concentre na questão das quotas a minorias para o acesso ao ensino superior público, S. SILVA identificou inúmeros atos normativos posteriores à promulgação da CF que também configuram medidas de ação afirmativa ${ }^{237}$, dos quais se destacam a Constituição do Estado da Bahia, que assegura a inclusão de indivíduos da raça negra na veiculação de publicidade estadual (art. 289), a Lei $n^{\circ} 8.213 / 91$, que estabelece quotas, de $2 \%$ a $5 \%$ das vagas de emprego em empresas privadas, a serem preenchidas por pessoas portadoras de deficiência, e a Lei $n^{0}$ 9.504/97, que estabelece que os partidos ou coligações reservem um mínimo de $30 \%$ e um máximo de $70 \%$ para as candidaturas de cada sexo.

Observa-se que as medidas de ação afirmativa no mundo compreendem um vasto espectro de estratégias, cada qual adaptada à sociedade na qual se pretende sua aplicação e delineada pelos objetivos politicamente determinados. Não se esgotam nos exemplos ilustrados nesta seção. O que se pretende é trazer os exemplos que, por suas peculiaridades, mais contribuíram para determinar os contornos do instituto da ação afirmativa de modo a fornecer os substratos necessários para a determinação de um conceito de ação afirmativa relativamente amplo, porém útil, ao que se planeja analisar neste trabalho - uma legítima working definition.

${ }^{234}$ Cf. SILvA, Sidney Pessoa Madruga da. Discriminação Positiva: Ações Afirmativas na Realidade Brasileira. Brasília: Brasília Jurídica, 2005, p. 129.

${ }^{235}$ Cf. ADI 3.197/RJ.

${ }^{236}$ Cf. Silva, Maria do Socorro da. Ações afirmativas para a população negra: um instrumento para a justiça social no Brasil. Dissertação (mestrado em Direito), Faculdade de Direito, Universidade de São Paulo, São Paulo, 2009, p.153.

237 Cf. Silva, Sidney Pessoa Madruga da. Discriminação Positiva: Ações Afirmativas na Realidade Brasileira. Brasília: Brasília Jurídica, 2005, p. 127-129. 


\subsection{Definição de ações afirmativas}

Das inúmeras e distintas experiências abordadas na seção anterior, há um denominador comum: as medidas de ação afirmativa configuram, sic et simpliciter, uma categoria de políticas públicas destinadas, em última análise, a promover a inclusão social, política e econômica de grupos de certo modo fragilizados.

São políticas públicas porque “[...] iniciam-se na formulação das decisões, na priorização dos problemas sociais a serem enfrentados e na busca de soluções (planejamentos, programações, e atos normativos, etc.) [...]"238. Envolvem uma abordagem ampla da questão da inclusão socioeconômica e não se restringem à mera tomada de decisões ou à mera edição de atos normativos sem um acompanhamento crítico dos resultados atingidos. São políticas públicas também porque são reservadas “[...] aos poderes instituídos, municípios, governos estaduais e o nacional, pois cabe a eles, que têm poderes e recursos necessários, a responsabilidade de implementar tais políticas.",239

As políticas de ação afirmativa, desse modo, pressupõem a ocorrência de desigualdades fáticas parciais que afetam um grupo social determinado. Pressupõem, ainda, uma decisão política de superação ou atenuação dessas desigualdades, um modèle de société, un choix politique ${ }^{240}$. Segundo R. DWORKIN, as medidas de ação afirmativa não se baseiam na ideia segundo a qual os grupos que recebem os benefícios imediatos têm direito definitivo ao tratamento jurídico diferenciado, “[...] mas apenas na hipóteses [sic] estratégica de que ajudá-los agora é uma maneira eficaz de atacar um problema

\footnotetext{
${ }^{238}$ PRUDENTE, Eunice Aparecida de Jesus. Experiências integradoras que o Brasil já conheceu: uma análise jurídica sobre a exclusão social dos afro-descendentes numa ordem constitucional integradora. In: DURHAM, Eunice R.; BorI, Carolina M. (Org.). Seminário: O Negro no Ensino Superior. São Paulo: Núcleo de Pesquisas sobre Ensino Superior, 2003, p. 104.

${ }^{239}$ MunANGA, Kabengele. O anti-racismo no Brasil. In: (Org.). Estratégias e Politicas de Combate à Discriminação Racial. São Paulo: Editora da Universidade de São Paulo, 1996, p. 83.

${ }^{240}$ Cf. GomeS, Joaquim B. Barbosa. A recepção do instituto da ação afirmativa pelo Direito Constitucional Brasileiro. Revista de Informação Legislativa, Brasília, a. 38, n. 151, p. 129-151, jul./set. 2001, p. 146.
} 
nacional."241 Justamente por conta da inexistência de direito definitivo ao tratamento juridicamente desigual, o estabelecimento de medidas de ação afirmativa em benefício de um grupo não precisa se estender aos demais grupos sociais que sofrem de semelhantes desigualdades fáticas parciais. Nesse sentido, definições amplas, porém completas, para as ações afirmativas são oferecidas por autores como P. MENEZES:

\begin{abstract}
Ação afirmativa, nos dias correntes, é um termo de amplo alcance que designa um conjunto de estratégias, iniciativas ou políticas que visam favorecer grupos ou segmentos sociais que se encontram em piores condições de competição em qualquer sociedade em razão, na maior parte das vezes, da prática de discriminações negativas, sejam elas presentes ou passadas. ${ }^{242}$
\end{abstract}

As medidas de ação afirmativa devem ser dirigidas a grupos ou categorias determinados que são afetados por desigualdades fáticas parciais. Por razões históricas, convencionou-se chamar tais grupos de "minorias": as medidas de ação afirmativa surgiram, no contexto norte-americano, dirigida aos negros daquele país, grupo etnicorracial quantitativamente minoritário. No entanto, em sua expansão, essas medidas logo passaram a contemplar grupos quantitativamente majoritários, como, em alguns casos, as mulheres. Atualmente, ao se tratar de medidas de ação afirmativa, entender "minorias" em seu sentido quantitativo não faz sentido. "Minorias" significam, nesse contexto, apenas grupos social, política ou economicamente fragilizados determinados que sofrem desigualdades fáticas parciais passíveis de serem remediadas por medidas de ação afirmativa.

As políticas de ação afirmativa se distinguem das demais políticas que visam aos mesmos objetivos mediatos pelo seu modus operandi: operam-se pelo estabelecimento de tratamentos juridicamente desiguais e, portanto, mediante o estabelecimento de restrições ao princípio da igualdade jurídica. Não se deve negar a existência de outros gêneros de políticas públicas que visam a alguns dos objetivos mediatos também visados pelas medidas de ação afirmativa. No caso do combate a discriminações, por exemplo, além da adoção de certas medidas de ação afirmativa, pode-se procurar coibir ou suprimir práticas

\footnotetext{
${ }^{241}$ DwORKIN, Ronald. Uma questão de princípio. Tradução Luís Carlos Borges. São Paulo: Martins Fontes, 2000 , p. 443.

${ }^{242}$ MENEZES, Paulo Lucena de. Ação afirmativa (affirmative action) no direito norte-americano. São Paulo: Revista dos Tribunais, 2001, p. 27.
} 
discriminatórias por meio de normas proibitivas ou inibitórias ${ }^{243}$. Contudo, em muitos casos, como se verá oportunamente, as medidas inibitórias ou universalistas são insuficientes, o que justifica, em certos casos, os tratamentos jurídicos desiguais estabelecidos pelas medidas de ação afirmativa.

Essas medidas, ainda que em conjunto com outros princípios constitucionais relevantes nos casos concretos, são calcadas no princípio da igualdade fática:

[...] políticas sociais de apoio e de promoção de determinados grupos socialmente fragilizados. [...] A essas políticas sociais, que nada mais são do que tentativas de concretização da igualdade substancial ou material [ = igualdade fática], dá-se a denominação de 'ação afirmativa' [...]..$^{244}$

Por conta da definição ampla de ação afirmativa, percebe-se que não se exclui, $a$ priori, qualquer política que possua as características já citadas. Seria problemático excluir alguma medida da categoria - da mesma forma que o é excluir alguma conduta ou posição jurídica do âmbito de proteção de um princípio - por conta da margem de arbitrariedade a que a atitude pode dar ensejo: como a adoção de políticas de ação afirmativa exige, além da demonstração das razões suficientes que justificam o estabelecimento de tratamentos desiguais, a existência dos pressupostos de fato que as autorizam, ao se excluir de antemão uma medida da categoria das ações afirmativas afasta-se a importância dessa necessária demonstração.

Em sua estrutura básica, as medidas de ação afirmativa são políticas públicas que, mediante o estabelecimento de tratamentos juridicamente desiguais específicos $\left(J_{\mathrm{d}}\right)$, visam a reduzir $(\neg)$ desigualdades fáticas parciais que afetam certos segmentos social ou economicamente fragilizados - minorias $-\left(F_{\mathrm{d}}\right)$ e, desse modo, promover a inclusão $(I)$ de tais segmentos:

$$
J_{\mathrm{d}} \rightarrow \neg F_{\mathrm{d}} \therefore I
$$

Nessa linha, qualquer medida que vise mediatamente à inclusão social, política ou econômica de um grupo de certo modo fragilizado mediante o estabelecimento de tratamento jurídico desigual é uma medida de ação afirmativa. O já mencionado estabelecimento de reserva de cargos e empregos públicos para as pessoas portadoras de

\footnotetext{
${ }^{243}$ Cf. Gomes, Joaquim B. Barbosa. Ação afirmativa \& princípio constitucional da igualdade. Rio de Janeiro: Renovar, 2001, p. 49.

${ }^{244}$ Gomes, Joaquim B. Barbosa. A recepção do instituto da ação afirmativa pelo Direito Constitucional Brasileiro. Revista de Informação Legislativa, Brasília, a. 38, n. 151, p. 129-151, jul./set. 2001, p. 131.
} 
deficiência (art. 37, VIII da CF) é uma medida de ação afirmativa. A Lei no 9.504/97, que estabelece que os partidos ou coligações reservem um mínimo de 30\% e um máximo de $70 \%$ para as candidaturas de cada sexo, também estabelece uma medida de ação afirmativa. A própria Lei Complementar no 123/06 estabelece medida de ação afirmativa ao favorecer as microempresas e empresas de pequeno porte no procedimento de licitação para contratação com o Estado, inclusive servindo a condição como critério de desempate $^{245}$.

As medidas de ação afirmativa, por sua vez, ao contrário do que afirma R. KAUFMANN $^{246}$, não se confundem com o que R. ALEXY chama de "ações positivas" "247. A autora está certa ao afirmar que as ações positivas, para R. ALEXY, são toda e qualquer prestação por parte do $E \operatorname{stado}^{248}$. Contudo, logo se percebe que nem toda prestação por parte do Estado é uma medida de ação afirmativa. Basta pensar nas medidas de caráter universalista. Por outro lado, toda medida de ação afirmativa se opera por intermédio de uma prestação estatal: uma prestação estatal normativa, que consiste em atos estatais de criação de normas. As prestações estatais normativas, juntamente com as prestações estatais fáticas, configuram as prestações por parte do Estado e se diferenciam entre si pelo critério da "[...] irrelevância da forma jurídica na realização da ação para a satisfação do direito [...]"249 . Nas medidas de ação afirmativa, a forma jurídica é fundamental, pois tem, inclusive, caráter definidor desse gênero de políticas públicas. Nesse contexto, as medidas de ação afirmativa estão contidas em um espectro de casos em que o enunciado da

\footnotetext{
245 “Art. 44. Nas licitações será assegurada, como critério de desempate, preferência de contratação para as microempresas e empresas de pequeno porte.

$\S 1^{\circ}$ Entende-se por empate aquelas situações em que as propostas apresentadas pelas microempresas e empresas de pequeno porte sejam iguais ou até $10 \%$ (dez por cento) superiores à proposta mais bem classificada.

$\S 2^{\circ} \mathrm{Na}$ modalidade de pregão, o intervalo percentual estabelecido no $\S 1^{\circ}$ deste artigo será de até $5 \%$ (cinco por cento) superior ao melhor preço."

${ }^{246}$ Cf. Kaufmann, Roberta Fragoso Menezes. Ações afirmativas à brasileira: necessidade ou mito? Porto Alegre: Livraria do Advogado, 2007, p. 220.

${ }^{247}$ Cf. Alexy, Robert. Teoria dos direitos fundamentais. Tradução Virgílio Afonso da Silva. São Paulo: Malheiros, 2008, p. 433 et seq.

248 "Se se adota um conceito amplo de prestação, todos os direitos a uma ação estatal positiva podem ser classificados como direitos a prestações estatais em um sentido mais amplo; de forma abreviada: como direitos a prestações em sentido amplo.” ALEXY, Robert. Teoria dos direitos fundamentais. Tradução Virgílio Afonso da Silva. São Paulo: Malheiros, 2008, p. 433. O próprio título do capítulo de onde o excerto foi extraído é "Direitos a ações estatais positivas (direitos a prestações em sentido amplo)".
}

249 AleXY, Robert. Teoria dos direitos fundamentais. Tradução Virgílio Afonso da Silva. São Paulo: Malheiros, 2008, p. 202. 
igualdade gera o dever de ação do Estado - no caso, criação de normas jurídicas que estabelecem tratamento desigual - e não o dever de abstenção do Estado de estabelecer discriminações:

\begin{abstract}
Por el contrario, en un interesante espectro de casos, los derechos de igualdad garantizan derechos que pertenecen al status positivo. Con el mismo argumento, entonces, también podrían demonimarse [sic] los derechos de igualdad como 'derechos modales de prestación', y podría aducirse para ello, que estos derechos exigen siempre una prestación, a saber: un tratamiento diferenciado en el marco de la acción estatal, que sea capaz de satisfacer las exigencias de los derechos de igualdad. $^{250}$
\end{abstract}

Ademais, convém salientar que não há um método específico de implementação das políticas de ação afirmativa. As chamadas "quotas" certamente são um dos métodos, mas não são o único. O método do estabelecimento de metas - ou quotas flexíveis - também é possível, ou até mesmo, seguindo a linha da suprema corte norte-americana fixada no caso Regents of the University of California v. Bakke, preferivel às quotas simples ${ }^{251}$. Há, ainda, “[...] o método do estabelecimento de preferências, o sistema de bônus e os incentivos fiscais [...]. Em outras palavras, ação afirmativa não se confunde nem se limita às cotas."252 Comparando-se as medidas de ação afirmativa com as medidas chamadas de universalistas - que não se destinam a uma minoria determinada -, percebe-se, seguindo a estrutura acima delineada, que são medidas que podem ter o mesmo fim mediato, ou seja, a inclusão de certos grupos especialmente fragilizados, mas o modo de se alcançar aquele objetivo é diverso: enquanto as medidas universalistas se propõem a melhorar a situação global da sociedade, as medidas de ação afirmativa visam a melhorar a situação de apenas uma ou algumas parcelas da sociedade que se encontram em particular desvantagem. É certo que os grupos fragilizados podem - e devem - se beneficiar das medidas de cunho universalista, mas são esses grupos o alvo específico das medidas de ação afirmativa.

Já o caráter político das políticas de ação afirmativa deve ser ressaltado. É uma das opções que se apresentam ao Estado na persecução dos fins constitucionalmente

\footnotetext{
${ }^{250}$ BOROWSKI, Martin. La estructura de los derechos fundamentales. Tradução Carlos Bernal Pulido. Bogotá: Universidad Externado de Colombia, 2003, p. 117-118.

${ }^{251}$ Cf. Kaufmann, Roberta Fragoso Menezes. Ações afirmativas à brasileira: necessidade ou mito? Porto Alegre: Livraria do Advogado, 2007, p. 228.

${ }^{252}$ Gomes, Joaquim B. Barbosa O debate constitucional sobre as ações afirmativas. Revista de Direitos Difusos, [S.1.], v. 9, p. 1133-1163, out. 2001, p. 1161.
} 
determinados $^{253}$. Se, dentre os fins determinados pela CF está o estabelecimento de uma sociedade justa e menos desigual (art. $3^{\circ}$, I e III), há reduzidas determinações constitucionais sobre como tais fins devem ser atingidos ou mesmo sobre quais fins, especificamente falando, são esses. Nesse sentido, a política é mais uma determinação dos meios que dos fins, integrando por excelência o espaço estrutural de R. AlEXY. Dos três espaços estruturais identificados pelo autor, que, em muitos casos, se entrelaçam, já se fez referência ao espaço de ponderação, relacionado ao "empate" no sopesamento de princípios colidentes. Neste ponto, merecem destaque os demais espaços estruturais, que são o espaço de determinação da finalidade e o espaço de escolha médio.

O espaço de determinação da finalidade, em resumo, consiste na possibilidade de se perseguir os fins não proibidos abstratamente pela constituição. O legislador, portanto, tem certa margem de manobra inclusive na determinação dos fins a serem perseguidos, assim como na "[...] determinação da medida de sua realização." 254 Desse modo, se, por um lado, há o mandamento de redução das desigualdades sociais e regionais, por outro, a CF pouco diz sobre quais são as desigualdades sociais ou regionais específicas que merecem atenção especial do Estado, sobre quais são as reduções prioritárias e muito menos sobre a medida da redução dessas desigualdades.

Ademais, mesmo que a constituição estabeleça um fim específico, pode não estabelecer precisamente quais as medidas a serem tomadas para a persecução de tal fim. Surge, assim, o espaço de escolha do meio, característico dos princípios que exigem uma prestação do Estado e não sua abstenção. "Se o dador de leis deve perseguir um objetivo e vários meios idôneos, por exemplo, em geral igualmente bons, estão à disposição, ele, fundamentalmente, tem a liberdade da escolha dos meios." ${ }^{255}$ No caso das medidas de ação afirmativa, o meio escolhido para se atingir os fins consiste em uma prestação normativa, a saber, a edição de normas juridicamente desiguais observando-se a proporcionalidade.

\footnotetext{
253 “A escolha das políticas públicas a serem implementadas ou, em outros termos, dos meios através dos quais as finalidades constitucionais podem ser alcançadas é atividade tipicamente reservada pela Constituição à definição político-majoritária." BARCELlOS, Ana Paula de. Neoconstitucionalismo, direitos fundamentais e controle das políticas públicas. In: CAMARGO, Marcelo Novelino (Org.). Leituras complementares de direito constitucional: direitos humanos e direitos fundamentais. $3^{\text {a }}$ ed. Salvador: JusPodivm, 2008, p. 146.

${ }^{254}$ AleXY, Robert. Constitucionalismo Discursivo. $2^{\mathrm{a}}$ ed. Tradução Luís Afonso Heck. Porto Alegre: Livraria do Advogado, 2008, p. 80.

${ }^{255}$ AleXY, Robert. Constitucionalismo Discursivo. $2^{\mathrm{a}}$ ed. Tradução Luís Afonso Heck. Porto Alegre: Livraria do Advogado, 2008, p. 80.
} 
As medidas de ação afirmativa são, em geral, uma opção para a promoção de fins gerais constitucionalmente determinados. Tornam-se inconstitucionais, contudo, quando desproporcionais. Há, excepcionalmente, casos de medidas de ação afirmativa obrigatórias, como no claro exemplo do estabelecimento de reserva de cargos e empregos públicos para as pessoas portadoras de deficiência (art. 37, VIII da CF). No Brasil, o espectro deôntico das medidas de ação afirmativa é amplo: na maioria dos casos, são medidas permitidas estão dentro da moldura constitucional -, mas há casos em que são obrigatórias e há casos em que seriam proibidas - configuram a moldura representada pela $\mathrm{CF}$.

O objetivo imediato das medidas de ação afirmativa é a redução de desigualdades fáticas parciais. É por essa razão que se diz que a decisão de reduzir tais desigualdades é pressuposta. E, além do mais, tal decisão é política, como explica R. AVI-YONAH, ao tratar especificamente da redução das desigualdades econômicas:

\begin{abstract}
Mas porque querer uma redução das desigualdades? $\mathrm{O}$ argumento de que as riquezas 'particulares' são, em parte, criadas pelas condições disponibilizadas pela própria sociedade e, por isso, podem ser redistribuídas 'como bem se aprouver', não é uma resposta satisfatória a esta pergunta, pois só legitima a redistribuição em si, mas não explica por que razão esta redistribuição é desejável. A resposta a esta pergunta é certamente política: em uma sociedade democrática, a maioria pode legitimamente decidir sobre a redistribuição de riqueza dos ricos para os pobres, mesmo que a sua única razão seja que as desigualdades são 'desleais' ou ofensivas (como, por exemplo, para Blum e Kalven). ${ }^{256}$
\end{abstract}

Além do argumento político da maioria, contudo, R. AVI-YONAH identifica outros argumentos que sustentam a conveniência da redistribuição dos bens escassos da sociedade a partir de uma perspectiva social: primeiramente, porque o acúmulo de riquezas - o que pode incluir qualquer bem escasso, como conhecimento ou postos de trabalho - traz poder ilegítimo a seus detentores ${ }^{257}$ e deixam de ser recursos privados quando passa a servir para controlar pessoas - e não coisas. Ademais, as desigualdades extremas trazem consequências negativas para a sociedade por conta do descontentamento a que dão ensejo:

\footnotetext{
${ }^{256}$ AvI-YONAH, Reuven. Os Três Objetivos da Tributação. Tradução Luís Flávio Neto. In: CostA, Alcides Jorge (Org.). Direito Tributário Atual, v. 22. São Paulo: Dialética, 2008, p. 18.

257 “Em nossa sociedade capitalista, o dinheiro é o 'bem dominador', e as pessoas que o possuem são as mais suscetíveis a acumular poder ilegítimo em outras esferas, como na política.” AvI-YONAH, Reuven. Os Três Objetivos da Tributação. Tradução Luís Flávio Neto. In: CostA, Alcides Jorge (Org.). Direito Tributário Atual, v. 22. São Paulo: Dialética, 2008, p. 19.
} 
Em especial, como Crane Brinton e Ted Gurr têm mostrado, as revoluções têm mais probabilidade de ocorrer em sociedades que tenham passado por um período de crescimento econômico, o que aumenta o nível de vida e as expectativas de todos os seus membros, seguido por choques externos ou internos que reduzem o nível de vida da maioria, não se alterando, entretanto, em relação aos ricos. ${ }^{258}$

Assim, as medidas que visam à redução das desigualdades não são essencialmente medidas altruísticas, mas podem servir a interesses puramente egoístas. Esse aspecto ficou muito claro por ocasião do surgimento das primeiras medidas de ação afirmativa nos Estados Unidos, na década de 1960, como forma de apaziguar grupos descontentes que estavam na iminência de partir para uma rebelião aberta ${ }^{259}$. No entanto, foge do escopo deste trabalho partir para uma análise aprofundada do processo de formação da vontade política, sendo possível partir para a questão dos fundamentos das medidas de ação afirmativa.

Antes de prosseguir, contudo, deve-se fazer um breve comentário acerca da "temporariedade" que se atribui às medidas de ação afirmativa. É certo que não se pode ignorar que a temporariedade dessas medidas está prevista no ordenamento jurídico brasileiro principalmente por conta da internalização da Convenção sobre a Eliminação de todas as Formas de Discriminação contra a Mulher (promulgada pelo Decreto $\mathrm{n}^{\mathrm{o}}$ 4.377/2002): o tratado afirma que não deverão ser consideradas discriminatórias certas medidas especiais destinadas a acelerar a igualdade de fato entre homens e mulheres, desde que temporárias $^{260}$.

Não obstante, no próprio âmbito do Direito Internacional dos Direitos Humanos, a Convenção Internacional sobre a Eliminação de todas as Formas de Discriminação Racial (promulgada pelo Decreto $n^{\circ}$ 65.810/1969) não traz a exigência de temporariedade de tais

\footnotetext{
${ }^{258}$ Avi-YonAH, Reuven. Os Três Objetivos da Tributação. Tradução Luís Flávio Neto. In: CostA, Alcides Jorge (Org.). Direito Tributário Atual, v. 22. São Paulo: Dialética, 2008, p. 20.

${ }^{259}$ Cf. Seção 2.1.

260 “Art. 4, $\S 1^{\circ}$ - A adoção pelos Estados-Partes de medidas especiais de caráter temporário destinadas a acelerar a igualdade de fato entre o homem e a mulher não se considerará discriminação na forma definida nesta Convenção, mas de nenhuma maneira implicará, como conseqüência, a manutenção de normas desiguais ou separadas; essas medidas cessarão quando os objetivos de igualdade de oportunidade e tratamento houverem sido alcançados."
} 
medidas. Esse tratado traz apenas a exigência de que elas não persistam "[...] após terem sido alcançados os seus objetivos"261.

$\mathrm{Na}$ definição de medidas de ação afirmativa como "medidas temporárias",262 ou "instrumento temporário de política social" "63 reside o equívoco de se subentender que sempre, em algum momento, a igualdade fática parcial será atingida mediante a política de ação afirmativa. Embora seja essa a vontade de muitos dos defensores de tal gênero de política pública, é perfeitamente possível cogitar desigualdades fáticas parciais que não são eliminadas, mas apenas compensadas, pelas medidas de ação afirmativa. Um exemplo seria a reserva de cargos e empregos públicos para as pessoas portadoras de deficiência (art. 37, VIII da CF), já que esses indivíduos têm desvantagens permanentes na competição pelas vagas ofertadas a todos, o que exige atenção permanente. Nesse ponto, a característica da "temporariedade" perde seu caráter definidor das medidas de ação afirmativa e passa a ser apenas contingente. S. SILVA sustenta noção parecida:

\begin{abstract}
Do mesmo modo, é bastante questionável propor que todas as espécies de ações afirmativas sejam implementadas em "caráter temporário", à medida que, assim considerado sem exceções, deixará de contemplar certas parcelas significativas da sociedade, como os índios, quilombolas e ciganos, cujas peculiaridades culturais e socioeconômicas demandam um constante acompanhamento e mudanças de estratégias e políticas dos órgãos governamentais.

Portanto a temporariedade, ou não, de certa medidas, integra o conceito das ações afirmativas $[\ldots]^{264}$
\end{abstract}

Em outros termos, se as medidas temporárias não são proibidas per se, muito menos a são as medidas que não trazem prazo determinado de duração ou mesmo as que possuem caráter permanente. Só faz sentido atribuir às medidas de ação afirmativa o caráter de "temporárias" se se entender que são temporárias aquelas medidas que, após ter sido atingido o seu objetivo, não deverão permanecer. Mas, por outro lado, é possível

261 “Art. 1, $\S 4^{\circ}$ - Não serão consideradas discriminação racial as medidas especiais tomadas com o único objetivo de assegurar progresso adequado de certos grupos raciais ou étnicos ou de indivíduos que necessitem da proteção que possa ser necessária para proporcionar a tais grupos ou indivíduos igual gozo ou exercício de direitos humanos e liberdades fundamentais, contando que, tais medidas não conduzam, em conseqüência, à manutenção de direitos separados para diferentes grupos raciais e não prossigam após terem sidos alcançados os seus objetivos."

${ }^{262}$ Cf. VILAS-BÔAS, Renata Malta. Ações afirmativas e o principio da igualdade. Rio de Janeiro: América Jurídica, 2003, p. 29.

${ }^{263}$ Cf. Kaufmann, Roberta Fragoso Menezes. Ações afirmativas à brasileira: necessidade ou mito? Porto Alegre: Livraria do Advogado, 2007, p. 220.

${ }^{264}$ Silva, Sidney Pessoa Madruga da. Discriminação Positiva: Ações Afirmativas na Realidade Brasileira. Brasília: Brasília Jurídica, 2005, p. 266. 
entender que qualquer norma jurídica que não mais atenda às razões que a sustenta não deve permanecer.

\subsection{Fundamentos das ações afirmativas}

O fato de as medidas de ação afirmativa instituírem tratamentos jurídicos desiguais exige que a diferença de tratamento seja devidamente justificada. Essa afirmativa, explícita ou implicitamente, resume a preocupação de quem estuda as medidas de ação afirmativa, ou mais, de quem sustenta ou rejeita determinadas medidas de ação afirmativa. A maioria dos trabalhos sobre o tema visa, em especial, a justificar - politicamente - a conveniência ou o acerto (ou a inconveniência ou o desacerto) das referidas medidas, pois é, de certo modo, intuitivo que tais medidas poderão ou deverão ser tomadas caso haja razões suficientes ou não deverão ser tomadas caso estejam ausentes justificativas plausíveis. Não é estranho, portanto, que a maioria dos trabalhos seja focada na "razão suficiente" que justifica o tratamento desigual de tal modo que R. FISCUS afirma que tudo o que poderia ser argumentado já o foi ${ }^{265}$.

Muito embora o presente estudo não tenha por objetivo analisar aprofundadamente as "razões suficientes" que justificam certas medidas de ação afirmativa, e sim o modo como as "razões suficientes" operam na restrição de certos princípios - de certa maneira, é um estudo mais formal que material -, não se pode deixar de lado algumas justificativas gerais para a adoção de medidas de ação afirmativa sob pena de se prejudicar, na próxima seção, a análise da possibilidade jurídica da adoção dessas políticas no Brasil.

De início, tendo-se em vista o enfoque metodológico utilizado, convém deixar claro que há uma relação intrínseca entre justiça, correção e justificação. Afirmar que algo é justo significa afirmar que algo é correto, ou seja, que é devidamente justificado. Ademais, perguntas sobre a justiça de uma medida é uma pergunta normativa: se algo é justo, é devido. R. ALEXY explica essa inter-relação:

${ }^{265}$ Cf. Fiscus, Ronald Jerry. The Constitutional Logic of Affirmative Action. Durham: Duke University Press, 1992, p. 3. 
Quien afirma que algo es justo afirma siempre y de algún modo, al mismo tiempo, que es correcto. Y quien afirma que algo es correcto sobreentiende que es susceptible de ser fundamentado, justificado, mediante razones. La tesis según la cual la justicia es corrección, por tanto, conduce directamente a la idea de la justicia como posibilidad de fundamentación, o justificación, mediante razones. Esto es, lleva a la luz una relación interna entre el concepto de justicia y el de fundamentación (justificación).

[...] Las cuestiones de justicia son cuestiones normativas. Lo que quiere decir que, cuando está en juego la justicia, entendida como fundamentación (justificación) mediante razones, aquello que está en cuestión es la posibilidad de fundamentar normas relativas a distribuciones y compensaciones $[\ldots]^{266}$

Desse modo, quem afirma que uma medida de ação afirmativa é justa quer dizer que tal medida se justifica, é correta e é devida. Os argumentos baseados em concepções de justiça seguem essa linha. Por exemplo, medidas de ação afirmativa devem ser adotadas para a distribuição equitativa de bens sociais escassos - argumento da justiça distributiva -, ou porque são medidas que, em última análise, favorecem toda a sociedade - argumento da utilidade. D. SARMENTO identifica quatro argumentos principais: justiça compensatória, justiça distributiva, promoção do pluralismo e fortalecimento da identidade e auto-estima do grupo favorecido ${ }^{267}$. Esses são exemplos de argumentos perfeitamente aptos a serem utilizados principalmente na fase do sopesamento entre os princípios colidentes, inclusive porque, no Brasil, não há respostas consolidadas na jurisprudência, nas leis ou na dogmática para a maior parte das questões que envolvem as medidas de ação afirmativa:

Se lei, precedente ou dogmática determinam, inequivocamente, a decisão e se, sob o aspecto da correção quanto ao conteúdo, não existem objeções sérias, o caso é decidido somente pelo fundado em autoridade e institucional. Mas, se lei, precedente e dogmática não determinam a resposta a uma questão jurídica, o que define casos difíceis, são necessárias valorações adicionais, que não se deixam depreender somente do material fundado em autoridade dado. [...] se o fundado em autoridade ou institucional sozinho não dá resposta, [é] possível somente no caminho da argumentação prática geral. Em seu quadro, reflexões de conformidade com a finalidade e idéias daquilo que é bom para a comunidade têm, sem dúvida, o seu lugar legítimo. ${ }^{268}$

\footnotetext{
${ }^{266}$ ALEXY, Robert. Justicia como corrección. Tradução Ana Inés Haquín. Doxa: cuadernos de filosofía del derecho, Alicante, n. 26, p. 161-173, 2003, p. 163-164.

${ }^{267}$ Cf. SARMENTO, Daniel. A igualdade étnico-racial no direito constitucional brasileiro: discriminação "de facto", teoria do impacto desproporcional e ação afirmativa. In: CAMARGO, Marcelo Novelino (Org.). Leituras complementares de direito constitucional: direitos humanos e direitos fundamentais. $3^{\mathrm{a}}$ ed. Salvador: JusPodivm, 2008, p. 218.

${ }^{268}$ AleXY, Robert. Constitucionalismo Discursivo. $2^{\mathrm{a}}$ ed. Tradução Luís Afonso Heck. Porto Alegre: Livraria do Advogado, 2008, p. 39-40.
} 
Já foi proposta a ideia segundo a qual as medidas de ação afirmativa se justificariam como forma de compensar discriminações, abusos ou danos passados. O argumento da justiça compensatória é uma espécie de "justiça retroativa" destinada a indivíduos que sofreram danos ou que foram discriminados no passado, inclusive oficialmente, cujo caso marcante é o dos negros brasileiros ${ }^{269}$. Esse argumento ainda é bastante sugerido, embora seja bastante frágil. Em primeiro lugar, é frágil porque quem sofreu abusos no passado, em regra, não é quem vai se beneficiar das medidas de ação afirmativa. Em segundo lugar, porque as entidades ou os indivíduos que serão prejudicados pelas medidas não serão, em regra, quem provocou os danos a serem compensados ${ }^{270}$. Como sugere J. GoMEs ${ }^{271}$, isso ilustra uma quebra da noção jurídica clássica de reparação de danos, que opera mediante as categorias de ato ilícito, dano e nexo de causalidade. Contudo, o argumento da justiça compensatória tem certo sentido se utilizado em um contexto de grupo, inferindo-se que os danos e discriminações sofridos no passado se refletem, ainda que de outra forma, nas gerações presentes pela operação de mecanismos inerciais de discriminação ${ }^{272}$. Assim, ainda que frágil, esse argumento ainda tem certa importância coadjuvante ${ }^{273}$.

O núcleo argumentativo a favor das medidas de ação afirmativa é a chamada "justiça distributiva": as medidas de ação afirmativa se justificam na medida em que servem para distribuir de forma mais equitativa os bens escassos na sociedade entre os

\footnotetext{
269 "Estas medidas discriminatórias para com o negro demonstram o desinteresse oficial em integrar o negro na vida política do País, mantendo-o em situação inferior." PrUDENTE, Eunice Aparecida de Jesus. Preconceito racial e igualdade jurídica no Brasil: a cidadania negra em questão. Campinas: Julex, 1989, p. 127.

${ }^{270}$ Cf. FISCus, Ronald Jerry. The Constitutional Logic of Affirmative Action. Durham: Duke University Press, 1992 , p. 8 et seq.

271 Cf. Gomes, Joaquim B. Barbosa. Ação afirmativa \& princípio constitucional da igualdade. Rio de Janeiro: Renovar, 2001, p. 65.

${ }^{272}$ Cf. Gomes, Joaquim B. Barbosa O debate constitucional sobre as ações afirmativas. Revista de Direitos Difusos, [S.1.], v. 9, p. 1133-1163, out. 2001, p. 1139.

${ }^{273}$ Cf. SARMENTO, Daniel. A igualdade étnico-racial no direito constitucional brasileiro: discriminação "de facto", teoria do impacto desproporcional e ação afirmativa. In: CAMARGO, Marcelo Novelino (Org.). Leituras complementares de direito constitucional: direitos humanos e direitos fundamentais. $3^{\mathrm{a}}$ ed. Salvador: JusPodivm, 2008, p. 219.
} 
diferentes grupos. Trata-se de justiça voltada para o presente ${ }^{274}$, que se opera mediante a constatação de falhas na distribuição equitativa dos bens entre os diversos grupos sociais:

\begin{abstract}
Portanto, sob essa ótica [da justiça distributiva], a ação afirmativa define-se como um mecanismo de 'redistribuição' de bens, benefícios, vantagens e oportunidades que foram indevidamente monopolizados por um grupo em detrimento de outros, por meio de um artifício moralmente e juridicamente condenável - a discriminação [...]. ${ }^{275}$
\end{abstract}

Uma conhecida formulação do argumento da justiça distributiva é apresentada por R. FISCUS: "[t]here is no violation of equal protection when society acts to restore the equilibrium that would have naturally occurred under nonracist conditions." $276 \mathrm{O}$ autor sustenta que as medidas de ação afirmativa se justificam na medida em que visam a corrigir desequilíbrios artificialmente criados. É possível aproximar a explicação de R. FISCUS de uma explicação "termodinâmica" para o equilíbrio na distribuição dos bens na sociedade. Supondo um sistema energeticamente isolado, as diferenças de temperatura sempre tenderão a se anular até que seja atingido o equilíbrio (temperatura uniforme) ${ }^{277}$. Substituindo-se o sistema pela sociedade e a temperatura pelos bens, os bens tenderiam a ser distribuídos na sociedade até que se atingisse um equilíbrio entre os diversos grupos sociais. Se for observada uma concentração de bens em determinado grupo - por exemplo, um grupo etnicorracial -, é forçoso concluir que o sistema não estava isolado ou, em outras palavras, que houve um acréscimo de entropia no interior do sistema. Desse modo, "[w]hen one finds race-based differences within a society there are but two possible explanations: racial superiority/inferiority at birth, or racism in the society" ${ }^{278} \mathrm{e}$ as medidas de ação afirmativa serviriam justamente para corrigir o desequilíbrio no sistema causado pela operação de mecanismos discriminatórios - única explicação para a concentração. Os

274 "Portanto, a luta é contra este presente concreto, atual, cotidiano, visível e comensurável e não contra um passado sobre o qual as novas gerações conhecem pouco ou mal através de manuais de história." MUNANGA, Kabengele. O anti-racismo no Brasil. In:___ (Org.). Estratégias e Políticas de Combate à Discriminação Racial. São Paulo: Editora da Universidade de São Paulo, 1996, p. 81-82.

${ }^{275}$ Gomes, Joaquim B. Barbosa. Ação afirmativa \& princípio constitucional da igualdade. Rio de Janeiro: Renovar, 2001, p. 68.

${ }^{276}$ Fiscus, Ronald Jerry. The Constitutional Logic of Affirmative Action. Durham: Duke University Press, 1992, p. 38 .

${ }^{277}$ Cf. Monod, Jacques. O acaso e a necessidade: ensaio sobre a filosofia natural da biologia moderna. Tradução Alice Sampaio. Mem Martins: Europa-América, 2002, p. 130.

${ }^{278}$ Fiscus, Ronald Jerry. The Constitutional Logic of Affirmative Action. Durham: Duke University Press, 1992, p. 24. 
grupos favorecidos pelas medidas, portanto, só receberiam o que naturalmente receberiam caso não houvesse o acréscimo de entropia no sistema representado pela discriminação.

$\mathrm{O}$ argumento da justiça distributiva traduz um dos pressupostos das medidas de ação afirmativa, que é a existência de desigualdades fáticas parciais que afetam certos segmentos social ou economicamente fragilizados, quaisquer que sejam as origens de tais desigualdades. Embora, na grande maioria dos casos, a discriminação seja a explicação ou, pelo menos, a explicação mais plausível - para a situação de desigualdade fática a ser remediada por uma medida de ação afirmativa, não é necessário que essa situação tenha sua origem na discriminação ${ }^{279}$. Em outras palavras, o acréscimo de entropia no interior do sistema, que representa a ocorrência de desigualdades fáticas "artificiais", não precisa ocorrer devido à discriminação: é perfeitamente possível pensar em outras causas, como a excessiva burocracia ou o regressivo sistema tributário que colocam as empresas de menor porte em situação de desvantagem frente a grandes corporações. Por outro lado, também é possível cogitar casos de grupos que, apesar de serem, de certo modo, discriminados, não chegam a ser colocados em situações de desigualdade fática relevantes, como ocorre, no Brasil, com certas minorias religiosas ou sexuais. Assim, fica clara a fragilidade da fundamentação baseada no argumento da justiça compensatória, pois muitas desigualdades fáticas parciais não decorrem de discriminações, abusos ou danos ocorridos no passado, nem todos os que os sofreram ou sofrem encontram-se em situações de desigualdade fática relevantes.

Muitos autores trazem ainda o argumento do benefício geral para sustentar o estabelecimento de medidas de ação afirmativa. Segundo essa linha, as referidas medidas não beneficiam apenas os integrantes do grupo beneficiado - beneficiados imediatos -, mas toda a coletividade - beneficiário mediato. Segundo J. RAWLS, uma medida de ação afirmativa, que estabelece um tratamento jurídico desigual, só seria justificada se todos ganhassem com ela ou, em outras palavras, “[...] inequalities are arbitrary unless it is reasonable to expect that they will work out for everyone's advantage $[\ldots]^{, 280}$. Desse modo, as medidas de ação afirmativa são boas para toda a coletividade por inúmeras razões, entre as quais a paz social, já que, como já foi exposto, o descontentamento surgido de situações de grande desigualdade podem comprometer a ordem social. Foge do objeto

${ }^{279}$ Cf. Menezes, Paulo Lucena de. Ação afirmativa (affirmative action) no direito norte-americano. São Paulo: Revista dos Tribunais, 2001, p. 27. O autor sustenta que as desigualdades fáticas parciais são decorrência de discriminação "na maioria das vezes".

${ }^{280}$ RAWLS, John. Collected Papers. Cambridge: Harvard University Press, 1999, p. 48. 
deste trabalho - e mesmo do objeto do Direito - expor pormenorizadamente todas as vantagens sociais ou econômicas que as medidas de ação afirmativa poderão trazer, ainda tais vantagens devam ser levadas em consideração na análise casuística servindo de argumentos que, em conjunto com outros, sustentem o estabelecimento de certos tratamentos jurídicos desiguais. Neste momento, basta o conhecimento de que medidas de ação afirmativa podem trazer benefícios a toda a coletividade e esse aspecto não deve ser ignorado:

\begin{abstract}
Trata-se, em suma, de um mecanismo sócio-jurídico destinado a viabilizar primordialmente a harmonia e a paz social, que são seriamente perturbadas quando um grupo social expressivo se vê à margem do processo produtivo e dos benefícios do progresso, bem como a robustecer o próprio desenvolvimento econômico do país. ${ }^{281}$
\end{abstract}

As medidas de ação afirmativa podem se justificar, ainda, pelo fomento ao pluralismo nas relações sociais ${ }^{282}$, valorizando, entre outros aspectos, a diversidade étnica e regional do país (art. 215, $\S 3^{\circ}, \mathrm{V}$ da CF). Ainda que inicialmente "à força", uma crescente presença de integrantes de grupos sociais de certo modo fragilizados em todos os aspectos da vida social, política e econômica promoverá a integração de tais grupos e, ainda, servirá de antídoto contra práticas discriminatórias. As medidas de ação afirmativa, dessa forma, cumprirão "[...] uma finalidade pública decisiva ao projeto democrático, que é a de assegurar a diversidade e a pluralidade social." ${ }^{283}$ Esse argumento se relaciona com o argumento do benefício geral na medida em que se supõem vantagens comparativas a sociedades que promovem o pluralismo.

Por fim, há que se mencionar que as medidas de ação afirmativa, em muitos casos, podem servir ao fortalecimento da identidade e da autoestima do grupo favorecido. Tais medidas, além de promoverem uma distribuição mais equitativa dos bens sociais escassos ou de promoverem a pluralidade nas relações sociais, também servem para promover o reconhecimento dos grupos sociais beneficiados. Em outras palavras e partindo de uma diferenciação entre problemas de distribuição de bens e problemas de reconhecimento

281 Gomes, Joaquim B. Barbosa O debate constitucional sobre as ações afirmativas. Revista de Direitos Difusos, [S.1.], v. 9, p. 1133-1163, out. 2001, p. 1138.

${ }^{282}$ Cf. Gomes, Joaquim B. Barbosa. A recepção do instituto da ação afirmativa pelo Direito Constitucional Brasileiro. Revista de Informação Legislativa, Brasília, a. 38, n. 151, p. 129-151, jul./set. 2001, p. 132.

283 Piovesan, Flávia; Piovesan, Luciana; SATO, Priscila Kei. Implementação do direito à igualdade. Cadernos de Direito Constitucional e Ciência Política, São Paulo, a. 5, n. 21, p. 139-145, out./dez. 1997, p. 143. 
proposta por N. FRASER, D. SARMENTO identifica os problemas de reconhecimento como sendo "[...] eminentemente culturais ou simbólicos, e dizem respeito ao modo como determinados grupos são enxergados no contexto social [...]"284. Nessa linha, as medidas de ação afirmativa poderão servir, ainda que indiretamente, à valorização das manifestações culturais, principalmente das culturas popular, indígena e afro-brasileira (art. 215 , caput e $\S 1^{\circ}$ da $\mathrm{CF}$ ) por intermédio da valorização dos indivíduos produtores dessa cultura $^{285}$.

Esta seção, todavia, ficaria incompleta se não fossem abordados os principais argumentos contrários às medidas de ação afirmativa. A passagem, no entanto, será mais superficial, pois o que interessa são os argumentos que buscam justificar a adoção de tais políticas uma vez que o ônus argumentativo é de quem pretende o estabelecimento de tratamentos jurídicos desiguais. Afinal, como já foi exposto ${ }^{286}$, a igualdade jurídica não requer justificativas ou, em outras palavras, quem pretende estabelecer medidas de ação afirmativa é quem deve ter bons argumentos.

No contexto das medidas de ação afirmativa adotadas nos Estados Unidos surgiu o conhecido argumento da "pessoa inocente", principal sustentação de posições contrárias às medidas de ação afirmativa que escapa do Direito e se converte em um argumento social de polarização racial ${ }^{287}$. Tal argumento consiste na constatação de que, ao se procurar reparar discriminações, abusos ou danos ocorridos no passado contra uma minoria, alguns poucos indivíduos da "maioria" - que, na maioria das vezes, não têm nenhuma responsabilidade pelo que ocorreu no passado - serão desproporcionalmente prejudicados. No caso das medidas de ação afirmativa baseadas no critério etnicorracial, cunhou-se, nos Estados Unidos, a expressão "branco inocente" para fazer referência aos indivíduos brancos que, mesmo que nunca tenham praticado qualquer ato discriminatório, terão seu acesso a bens sociais escassos restringido em proveito de indivíduos negros (por exemplo, terão seu acesso ao ensino superior negado em proveito de candidatos negros com pior

${ }^{284}$ SARMENTO, Daniel. A igualdade étnico-racial no direito constitucional brasileiro: discriminação "de facto", teoria do impacto desproporcional e ação afirmativa. In: CAMARGO, Marcelo Novelino (Org.). Leituras complementares de direito constitucional: direitos humanos e direitos fundamentais. $3^{\mathrm{a}}$ ed. Salvador: JusPodivm, 2008, p. 204-205.

285 Cf. MunAngA, Kabengele. O anti-racismo no Brasil. In: (Org.). Estratégias e Politicas de Combate à Discriminação Racial. São Paulo: Editora da Universidade de São Paulo, 1996, p. 86.

${ }^{286}$ Cf. Seção 1.3 .

${ }^{287}$ Cf. Fiscus, Ronald Jerry. The Constitutional Logic of Affirmative Action. Durham: Duke University Press, 1992, p. 7. 
desempenho escolar). Logo se percebe que se trata de uma resposta ao argumento da justiça reparatória e que não faz sentido diante do argumento da justiça distributiva. R. FISCUS é claro ao sustentar que, ao buscar justificar as medidas de ação afirmativa pelo argumento da justiça distributiva, o argumento da "pessoa inocente" cai por terra: a pessoa não seria "inocente" porque também não teria acesso aos bens de que foi privada em uma situação ideal - um sistema isolado. Assim, a "pessoa inocente", que seria beneficiada com o acesso a bens sociais escassos por conta da operação de mecanismos discriminatórios na sociedade, apenas não os receberiam: "[i]f individuals are entitled to what they would get in a fair world, then what they would not get they are not entitled to."288

Ademais, há quem sustente que a adoção de medidas de ação afirmativa, em vez de combater a discriminação, acabariam por reforçá-la, principalmente por conta da estigmatização dos grupos favorecidos ${ }^{289}$. Trata-se, contudo, de uma prognose incerta, principalmente no Brasil, por conta das peculiaridades da discriminação "à brasileira"290 .

Por fim, merece menção o argumento segundo o qual certas medidas de ação afirmativa violariam o princípio do mérito, tão caro ao ideal republicano, principalmente no que diz respeito ao acesso aos níveis mais elevados do ensino e pesquisa (art. 208, V da $\mathrm{CF}$ ). De início, convém refinar o que se entende pelo princípio do mérito: se "mérito da chegada" ou "mérito da trajetória",291. O mérito da chegada se refere ao resultado "na linha de chegada", ao resultado absoluto, sem serem levadas em consideração as condições iniciais dos competidores (exemplos clássicos são os vestibulares e os concursos públicos). Já o mérito da trajetória se refere ao resultado relativo, considerando-se mais meritório não quem tenha obtido o melhor desempenho absoluto, mas quem tenha obtido o melhor desempenho levando-se em conta os recursos à disposição de cada competidor; em outras palavras, busca-se quem tenha conseguido o máximo de resultado com o mínimo de

${ }^{288}$ Fiscus, Ronald Jerry. The Constitutional Logic of Affirmative Action. Durham: Duke University Press, 1992, p. 13.

${ }^{289}$ Cf. MunAnga, Kabengele. O anti-racismo no Brasil. In: (Org.). Estratégias e Politicas de Combate à Discriminação Racial. São Paulo: Editora da Universidade de São Paulo, 1996, p. 92.

${ }^{290}$ Cf. MunAnga, Kabengele. Políticas de ação afirmativa em benefício da população negra no Brasil: um ponto de vista em defesa de cotas. In: Silva, Petronilha Beatriz Gonçalves e, SilvérIo, Valter Roberto (Org.). Educação e ações afirmativas: entre a injustiça simbólica e a injustiça econômica. Brasília: Instituto Nacional de Estudos e Pesquisas Educacionais Anísio Teixeira, 2003, p. 126.

291 Cf. Silva, Sidney Pessoa Madruga da. Discriminação Positiva: Ações Afirmativas na Realidade Brasileira. Brasília: Brasília Jurídica, 2005, p. 214. 
recursos, sendo, portanto, um exame mais complexo que envolve a análise da própria história de vida dos competidores.

Se se entender o princípio do mérito enquanto mérito da trajetória, as medidas de ação afirmativa sequer restringiriam tal princípio. Ao contrário, o fomentaria ao levarem em consideração fatores pertinentes ao trajeto, a exemplo da discriminação. O mérito da chegada, por sua vez, é criticado por ser "[...] in fact a false merit because it is based on unfair competition, although the unfairness will often be undetectable." ${ }^{292}$ No entanto, se for atribuída à obrigatoriedade da adoção do critério do mérito da chegada o caráter de princípio e tendo-se em vista tudo o que já foi tratado neste estudo a respeito da estrutura dos princípios jurídicos, é forçoso concluir que, justamente por ser um princípio, é restringível. Certas medidas de ação afirmativa, se proporcionais, estabelecerão restrições ao princípio do mérito - entendido aqui como o mérito da chegada - da mesma forma que estabelecerão restrições ao princípio da igualdade jurídica ou a tantos outros princípios. Por serem restrições, serão legítimas e não há que se falar em violação. O princípio do mérito, dessa forma, seria apenas mais uma das variáveis a serem levadas em consideração no exame da proporcionalidade.

Os argumentos aqui expostos são exaustivamente trabalhados principalmente pelos autores citados. O aspecto relevante desta seção reside na percepção de que, na fundamentação de relações condicionadas de precedência, o conhecimento e a exposição de cada um dos argumentos se tornam essenciais para uma adequada avaliação da medida de ação afirmativa específica submetida ao exame da proporcionalidade, até mesmo porque qualquer argumento possível vale na fundamentação de precedência condicionadas ${ }^{293}$.

\footnotetext{
${ }^{292}$ Fiscus, Ronald Jerry. The Constitutional Logic of Affirmative Action. Durham: Duke University Press, 1992, p. 14.

${ }^{293}$ AlEXY, Robert. Teoria dos direitos fundamentais. Tradução Virgílio Afonso da Silva. São Paulo: Malheiros, 2008, p. 166.
} 


\section{CAPÍTULO 3 - AÇÕES AFIRMATIVAS E O PRINCÍPIO DA IGUALDADE}

\subsection{Sobre a juridicidade das ações afirmativas no Brasil}

Nesta seção será abordada a possibilidade jurídica de se implementar medidas de ação afirmativa no Brasil. Mantendo-se dentro do enfoque proposto - e ao contrário, por exemplo, de R. KAUFMANN ${ }^{294}$-, não será pressuposta a constitucionalidade das medidas de ação afirmativa para então se averiguar sua conveniência ou inconveniência social e política. Essa é tarefa das ciências sociais, econômicas e políticas, que foge do fato de que a constitucionalidade desse gênero de políticas públicas é mais problemática do que aparenta ser. A abordagem seguirá o caminho contrário: será pressuposta a conveniência social e política das medidas de ação afirmativa para então se averiguar sua constitucionalidade, até porque uma decisão política é um pressuposto para a implementação de qualquer medida de ação afirmativa.

Como já se afirmou, há medidas de ação afirmativa que se enquadram em todos os modais deônticos. Em outras palavras, há medidas de ação afirmativa constitucionalmente obrigatórias, proibidas ou simplesmente permitidas. Esse fato, por sua vez, exclui a análise abstrata da constitucionalidade das medidas de ação afirmativa ou dos critérios de diferenciação de que essas medidas se valem. A análise deve ocorrer necessariamente caso a caso.

Primeiramente - e excepcionalmente -, há medidas de ação afirmativa constitucionalmente obrigatórias. Mais uma vez se cita o exemplo da reserva de cargos e empregos públicos para as pessoas portadoras de deficiência (art. 37, VIII da CF). O legislador ordinário não tem escolha: deve estabelecer a medida de ação afirmativa ordenada na modalidade estabelecida (reserva de vagas). Outro exemplo seria a gratuidade

${ }^{294}$ Cf. KaUfmann, Roberta Fragoso Menezes. Ações afirmativas à brasileira: necessidade ou mito? Porto Alegre: Livraria do Advogado, 2007, p. 25. 
do registro civil de nascimento e da certidão de óbito para os reconhecidamente pobres (art. $5^{\circ}$, LXXVI da CF), que é caso de medida de ação afirmativa concretizada mediante uma imunidade tributária ${ }^{295}$. Tais medidas não despertam grandes problemas.

A grande discussão reside nas medidas facultadas ou proibidas, principalmente em razão da infinitude de medidas de ação afirmativa que se podem enquadrar nesses modais. De fato, a CF não traz especificamente quais são os critérios para se distinguir, a priori, as medidas de ação afirmativa permitidas das proibidas. Isso não significa, contudo, que outras medidas de ação afirmativa não previstas na CF não possam ser adotadas: significa apenas que o constituinte não estabeleceu previamente a solução para algumas colisões entre princípios, em especial entre o princípio da igualdade fática e o princípio da igualdade jurídica, deixando-a a cargo do legislador.

Deve-se, neste ponto, lembrar que tantas serão as relações condicionadas de precedência quantos forem os casos concretos em que há colisão entre princípios. Com base no princípio da igualdade fática, é perfeitamente possível estabelecer tratamentos jurídicos diferenciados, restringindo-se o princípio da igualdade jurídica ou outros princípios. O fato de a CF não trazer autorização geral expressa para a adoção de medidas de ação afirmativa - bem como seus critérios, limites e modalidades - não significa que esse gênero de políticas públicas seja vedado porque supostamente violaria o princípio constitucional da igualdade jurídica ou outros princípios igualmente relevantes.

No caso brasileiro, aliás, é curioso notar que se pode afirmar, seguindo a linha de respeitável parte da doutrina, que há previsão expressa de hierarquia constitucional para a adoção de medidas de ação afirmativa que se utilizam dos critérios etnicorracial e de gênero. Seriam, assim, medidas expressamente permitidas. Isso ocorre por conta da internalização da Convenção Internacional sobre a Eliminação de todas as Formas de Discriminação Racial (promulgada pelo Decreto $n^{\circ}$ 65.810/1969) e da Convenção sobre a Eliminação de todas as Formas de Discriminação contra a Mulher (promulgada pelo Decreto $\left.n^{0} 4.377 / 2002\right)$. Por serem tratados internacionais que versam sobre direitos humanos, seriam internalizados com hierarquia constitucional, ao contrário dos tratados que versam sobre outros temas, internalizados, esses sim, com hierarquia de lei ordinária. A. TRindade e F. Piovesan, entre outros, principalmente em virtude do art. $5^{\circ}, \S 2^{\circ}$ da

${ }^{295}$ Cf. CARvalho, Paulo de Barros. Curso de Direito Tributário. 17ª ed. São Paulo: Saraiva, 2005, p. 196. 
$\mathrm{CF}^{296}$, vislumbram esse regime jurídico diferenciado para os tratados que versem sobre direitos humanos ${ }^{297} \mathrm{e}$, por conseguinte, muitas categorias de medidas de ação afirmativa estão expressamente autorizadas:

\begin{abstract}
Assim, à luz desta respeitável doutrina, pode-se concluir que o Direito Constitucional brasileiro abriga, não somente o princípio e as modalidades implícitas e explícitas de ação afirmativa a que já fizemos alusão, mas também as que emanam dos tratados internacionais de direitos humanos assinados pelo nosso país. ${ }^{298}$
\end{abstract}

Mesmo se não for adotada a teoria da hierarquia constitucional, como parece ser a postura do $\mathrm{STF}^{299}$, há, pelo menos, autorização legal (ou "supralegal”) geral para a adoção de medidas de ação afirmativa que se utilizam dos critérios etnicorracial e de gênero que sustenta formalmente o estabelecimento dessas medidas de ação afirmativa por atos normativos infralegais (ex: decretos, portarias, deliberações de conselhos universitários, etc.). Isso decorre da exigência de competência para restringir um direito fundamental exigência formal (competência) ao lado da exigência material (proporcionalidade em sentido amplo) $)^{300}$-, ou seja, para que as restrições possam, eventualmente, se justificar materialmente, devem ser estabelecidas pelo sujeito competente. Como não há exigência formal específica para a restrição do princípio da igualdade jurídica - nem para a restrição da maioria dos princípios constitucionais que podem eventualmente ser restringidos por medidas de ação afirmativa -, diplomas com hierarquia de lei ordinária podem formalmente determinar tais restrições:

\footnotetext{
296 "§ $2^{\circ}$ - Os direitos e garantias expressos nesta Constituição não excluem outros decorrentes do regime e dos princípios por ela adotados, ou dos tratados internacionais em que a República Federativa do Brasil seja parte."

${ }^{297}$ Cf. Montebello, Marianna. As Políticas de Ação Afirmativa sob a Perspectiva do Direito Internacional dos Direitos Humanos. Interesse Público, Porto Alegre, a. 6, n. 29, p. 117-138, jan./fev. 2005, p. 130.

298 Gomes, Joaquim B. Barbosa O debate constitucional sobre as ações afirmativas. Revista de Direitos Difusos, [S.1.], v. 9, p. 1133-1163, out. 2001, p. 1158.

${ }^{299}$ Cf. RE 349.703/RS. Por maioria de votos, o STF decidiu que “[...] o caráter especial desses diplomas internacionais sobre direitos humanos lhes reserva lugar específico no ordenamento jurídico, estando abaixo da Constituição, porém acima da legislação interna. O status normativo supralegal dos tratados internacionais de direitos humanos subscritos pelo Brasil torna inaplicável a legislação infraconstitucional com ele conflitante $[\ldots]^{\prime}$.

${ }^{300}$ Cf. Borowski, Martin. La estructura de los derechos fundamentales. Tradução Carlos Bernal Pulido. Bogotá: Universidad Externado de Colombia, 2003, p. 123.
} 
La cláusula del principio general de igualdad no incluye dentro de su formulación literal ninguna habilitación para las intervenciones estatales. No obstante, de esto no puede derivarse que no se trata de un derecho fundamental restringible. [...] Frente a las ventajas que ofrece el modelo de la teoría externa, que presupone la existencia de una habilitación para la intervención en el derecho fundamental, debe partirse entonces de la idea de que existe esta habilitación y de que se trata de una habilitación no escrita. ${ }^{301}$

Contudo, mesmo diante da ausência de autorização geral expressa, seja ela de hierarquia constitucional, supralegal ou legal, as medidas de ação afirmativa baseadas nos critérios etnicorracial e de gênero não seriam proibidas per se, assim como não são proibidas as medidas de ação afirmativa baseadas em outros critérios. Isso ocorre porque atos normativos infraconstitucionais em sentido amplo (ou seja, qualquer ato normativo) podem restringir certos princípios constitucionais desde que sejam sustentados por outros princípios constitucionais. Em outros termos, atos normativos que estabelecem uma medida de ação afirmativa, desde que observada a proporcionalidade em sentido amplo, podem estabelecer validamente restrições ao princípio da igualdade jurídica, mesmo que não sejam leis em sentido estrito (que só seriam necessárias se ocorresse, mediante o estabelecimento de uma medida de ação afirmativa, uma restrição severa ao princípio da igualdade jurídica ou a outro princípio eventualmente colidente):

\begin{abstract}
Al igual que ocurre en el caso de los derechos de defensa, existiría la posibilidad de postular una protección formal general frente a la igualdad. En este caso, toda diferenciación tendría que estar legitimada mediante una Ley del Parlamento. Esto implicaría imponer exigencias de justificación exageradas. Junto a ello, en cambio, parece más razonable exigir sólo que la legitimación formal mediante una Ley del Parlamento se produzca cuando se trate de un trato diferenciado intenso, es decir, cuando se presente una intervención intensa en el derecho prima facie a obtenir un trato jurídico igual. ${ }^{302}$
\end{abstract}

O principal problema na aferição da constitucionalidade de certas medidas de ação afirmativa consiste, em última análise, na adoção, ainda que inconsciente, de uma teoria interna dos direitos fundamentais: o conteúdo do enunciado da igualdade é definido internamente, ou seja, há apenas um objeto, que é o direito com seus limites imanentes. Assim, são excluídas a priori condutas, estados ou posições jurídicas do âmbito de proteção do enunciado da igualdade, o que traz como consequência deficiências na

\footnotetext{
${ }^{301}$ BorowsKI, Martin. La estructura de los derechos fundamentales. Tradução Carlos Bernal Pulido. Bogotá: Universidad Externado de Colombia, 2003, p. 224.

302 BorowsKi, Martin. La estructura de los derechos fundamentales. Tradução Carlos Bernal Pulido. Bogotá: Universidad Externado de Colombia, 2003, p. 225.
} 
argumentação constitucional: pressupõe-se que tais condutas, estados ou posições jurídicas estão ou não estão incluídas no suporte de fato do enunciado da igualdade ${ }^{303}$. Assim, são comuns recursos argumentativos como: "[d]iversos dispositivos da Constituição da República de 1988 parecem legitimar os movimentos de discriminação positiva [...] ${ }^{, 304}$ ou “[j]á que se busca promover o bem de todos então temos uma determinação para que possamos utilizar as ações afirmativas. $" 305$ Em comum, essas linhas excluem, sem maiores questionamentos, aspectos incluídos no suporte de fato da igualdade jurídica restringida pelas medidas de ação afirmativa. Dessa forma, exige-se pouca ou nenhuma fundamentação para a adoção de medidas de ação afirmativa - pois se intui sê-las permitidas - quando, na verdade, exige-se uma sólida fundamentação para tais medidas restritivas do princípio da igualdade jurídica e de outros princípios igualmente relevantes. O mesmo vale para o contrário, ou seja, para quem procura excluir a priori medidas de ação afirmativa que se baseiam em certos critérios de diferenciação (a exemplo do gênero ou raça) do suporte de fato do princípio da igualdade fática.

Outro problema consiste na utilização do que será chamado de "proporcionalidade clássica" na análise da constitucionalidade das medidas de ação afirmativa no lugar da máxima da proporcionalidade delineada neste estudo. A proporcionalidade clássica consiste, grosso modo, na noção de adequação entre meios e fins surgida no campo do Direito Administrativo - daí ser possível chamá-la também de "proporcionalidade administrativa" -, não se confundindo com a máxima da proporcionalidade que serve para apurar a legitimidade de vulnerações a princípios constitucionais. A proporcionalidade administrativa aduz que "[...] os atos cujos conteúdos ultrapassem o necessário para alcançar o objetivo que justifica o uso da competência ficam maculados de ilegitimidade [...]"306, ou seja, deve-se adotar a conduta menos gravosa possível na persecução do interesse público ponderando-se meios e fins. Desde logo se percebe que o fim a ser

\footnotetext{
${ }^{303}$ Cf. SILVA, Virgílio Afonso da. Direitos fundamentais: conteúdo essencial, restrições e eficácia. $2^{\mathrm{a}}$ ed. São Paulo: Malheiros, 2010, p. 248.

${ }^{304}$ Montebello, Marianna. As Políticas de Ação Afirmativa sob a Perspectiva do Direito Internacional dos Direitos Humanos. Interesse Público, Porto Alegre, a. 6, n. 29, p. 117-138, jan./fev. 2005, p. 123.

${ }^{305}$ VILAS-BôAS, Renata Malta. Ações afirmativas e o princípio da igualdade. Rio de Janeiro: América Jurídica, 2003, p. 54.

${ }^{306}$ Mello, Celso Antônio Bandeira de. Curso de direito administrativo. $26^{\mathrm{a}}$ ed. São Paulo: Malheiros, 2009, p. 110 .
} 
atingido é um ponto fixo a partir do qual se analisa a proporcionalidade clássica dos meios a serem utilizados para sua consecução, como também percebe E. BÖCKENFÖRDE:

\begin{abstract}
Esta [la proporcionalidad clásica] tiene un punto fijo de referencia, el fin de la ley o de la norma legal, y determina a partir de éste (relacionalmente) la adecuación, la necesidad y la proporcionalidad en sentido estricto. Este punto fijo de referencia falta precisamente, y debe faltar, en la ponderación entre contenidos jurídico-objetivos de derecho fundamental y su intensidad de eficacia. Si existiera, atribuiría una posición de supremacía al (o a un) contenido de derecho fundamental en el que se asentara. ${ }^{307}$
\end{abstract}

O raciocínio calcado na proporcionalidade clássica, conquanto seja um instrumento essencial para se aferir a legalidade de atos na esfera do Direito Administrativo, não se mostra apropriado no espaço da dogmática dos direitos fundamentais, onde não há aquele ponto fixo representado pelo fim estabelecido nas leis. No âmbito dos direitos fundamentais, os próprios fins constitucionalmente determinados colidem entre si: são mais integrantes da equação que pontos de referência.

De qualquer maneira, o problema não reside na proporcionalidade clássica em si como já foi dito, é instrumento de suma importância no Direito Administrativo -, mas no fato de se fazer uso da proporcionalidade clássica para a análise da constitucionalidade de tratamentos jurídicos diferenciados. A título de exemplo, toma-se o fomento a algum aspecto qualquer do princípio da igualdade fática como o fim a ser atingido, pressupondose que é um fim ordenado - o ponto fixo -, o que traz como consequencias ser esse fim superior aos muitos outros fins também estabelecidos na CF e a limitação da discussão ao estabelecimento do meio menos gravoso para se atingir aquele fim. $\mathrm{Na}$ verdade, segundo a máxima da proporcionalidade, os próprios fins estabelecidos por princípios constitucionais devem entrar na análise da proporcionalidade em sentido amplo.

Pode-se perceber que o exame da proporcionalidade em sentido amplo não exclui muitos critérios já estabelecidos para se separar diferenciações jurídicas válidas das inválidas. Ao contrário, inclui novas exigências a serem observadas. Veja-se, por exemplo, que todos os critérios sugeridos por C. MELLO para se averiguar a constitucionalidade de tratamentos jurídicos desiguais são apreciados por ocasião do exame de proporcionalidade. O autor entende que não haverá violação ao princípio da igualdade se o critério de diferenciação não adotar um traço específico que singularize um único sujeito, se houver

\footnotetext{
307 BÖCKENFÖRDE, Ernst-Wolfgang. Escritos sobre Derechos Fundamentales. Tradução Juan Luis Requejo Pagés e Ignacio Villaverde Menéndez. Baden-Baden: Nomos, 1993, p. 124.
} 
correlação lógica entre o critério de diferenciação adotado e a disparidade de regimes outorgados e se essa correlação for compatível com interesses prestigiados na $\mathrm{CF}^{308}$. Esse entendimento permitiria concluir que “[...] qualquer diferença real e logicamente demonstrável, que possa dispensar tratamento diferenciado, é por si motivo de discriminações válidas" ${ }^{\text {309, }}$ quando, na verdade, exige-se mais. Os critérios acima sugeridos - com exceção do primeiro, decorrente da universalidade que caracteriza as leis emanadas do parlamento ${ }^{310}$ - nada mais parecem ser que o exame da adequação: se o tratamento jurídico diferenciado de algum modo fomenta um objetivo constitucionalmente previsto. $\mathrm{O}$ exame da proporcionalidade em sentido amplo, portanto, é mais rigoroso no que diz respeito à constitucionalidade de tratamentos jurídicos diferenciados.

A título de exemplo, e aproveitando-se para dar início à questão do critério de diferenciação etnicorracial, suponha-se que seja aprovada uma lei que determine que todas as vagas oferecidas em universidades e escolas técnicas públicas sejam destinadas a pessoas de cor negra ou parda. Essa lei imaginária atenderia a todos os critérios propostos por C. MELlo, pois o critério de diferenciação residiria nas pessoas diferenciadas (no caso, a raça ou a cor), não seria norma que tenha um destinatário determinado, seria compatível com interesses prestigiados na CF (no caso, a redução de desigualdades fáticas parciais, tendo-se em vista o fato de que pessoas negras e pardas possuem, em média, grau de instrução e remuneração inferiores ao de pessoas brancas) e haveria correlação lógica entre o critério de diferenciação adotado e a disparidade de regimes outorgados. Contudo, ainda que essa lei passasse pelo crivo da necessidade - se não houvesse qualquer outra medida que fomentasse o objetivo visado em igual ou maior intensidade e que restringisse menos os princípios colidentes -, dificilmente se poderia sustentar ser ela proporcional em sentido estrito por conta da enorme intensidade da restrição ao princípio da igualdade jurídica ${ }^{311}$. Por outro lado, o grande mérito do estudo de C. MELLO, além da proposta de critérios práticos destinados a se aferir a constitucionalidade de tratamentos juridicamente

${ }^{308}$ Cf. Mello, Celso Antônio Bandeira de. O conteúdo jurídico do princípio da igualdade. $3^{\text {a }}$ ed. São Paulo: Malheiros, 1998, p. 17-22.

${ }^{309}$ AtChaBAhian, Serge. Principio da igualdade e ações afirmativas. São Paulo: RCS, 2004, p. 84.

310 "[...] que se referem a todos os indivíduos de uma classe aberta [...]" ALEXY, Robert. Teoria dos direitos fundamentais. Tradução Virgílio Afonso da Silva. São Paulo: Malheiros, 2008, p.87.

311 "Viewed solely in terms of what the minority groups are theoretically entitled to, this would not be unreasonable. The problem is that it would give the minority what the majority owes it, by taking it from only a small percentage of the majority - one narrow age cohort." FISCUS, Ronald Jerry. The Constitutional Logic of Affirmative Action. Durham: Duke University Press, 1992, p. 52-53. 
desiguais, consiste na conclusão de que "[...] qualquer elemento residente nas coisas, pessoas ou situações, pode ser escolhido pela lei como fator discriminatório [...]"312. Com essa observação, passa-se à seção seguinte.

\subsection{Sobre a juridicidade do critério de diferenciação etnicorracial}

O ponto central desta seção reside na averiguação da possibilidade de o critério etnicorracial servir de fator para tratamentos jurídicos diferenciados. Esse assunto é de especial importância no Brasil, pois há apenas poucos anos que se passaram, de modo ainda restrito, a ser estabelecidas medidas de ação afirmativa baseadas no critério em pauta e não há, ainda, manifestação definitiva do STF quanto à constitucionalidade de tais medidas.

Com efeito, a CF estabelece que o Estado brasileiro deve promover o bem de todos "[...] sem preconceitos de origem, raça, sexo, cor, idade e quaisquer outras formas de discriminação." (art. 3, IV) e que "[t]odos são iguais perante a lei, sem distinção de qualquer natureza [...]” (art. $5^{\circ}$, caput). Conforme já se abordou por ocasião da análise do enunciado da igualdade, não se sustenta o entendimento segundo o qual a lei não pode criar distinções entre pessoas. A questão polêmica reside na possibilidade de se utilizar algum dos critérios a primeira vista proibidos, que são aqueles arrolados no art. $3^{\circ}$, IV da CF entre os quais a cor e a raça.

É possível sustentar, com base na divisão entre discriminação (diferenciação injustificada) e distinção (diferenciação justificada) por conta da carga semântica negativa do primeiro termo, que a CF proíbe somente as diferenciações injustificadas discriminação -, mas não as diferenciações devidamente justificadas - distinção - que se servem dos critérios de diferenciação arrolados no art. $3^{\circ}$, IV da CF ou de quaisquer outros. Contudo, essa separação de significados entre os termos não é necessária e nem parece que o constituinte se preocupou com essa minúcia terminológica, além de esbarrar-se com a proibição da "distinção" de qualquer natureza (art. 5, caput da CF). Assim, é lícito

\footnotetext{
${ }^{312}$ Mello, Celso Antônio Bandeira de. O conteúdo jurídico do principio da igualdade. $3^{\text {a }}$ ed. São Paulo: Malheiros, 1998, p. 17.
} 
sustentar que os termos "discriminação" e "distinção", pelo menos nos enunciados normativos em questão, são termos sinônimos e querem dizer "diferenciação" - tanto as justificadas quanto as injustificadas.

Então surge a seguinte questão: se é possível a distinção com base em outros critérios, também o é com base em um dos critérios expressamente elencados no art. $3^{\circ}, \mathrm{IV}$ da CF? O constituinte, ao mencionar expressamente esses critérios, não procurou chamar para eles mais atenção que para os demais critérios? As indagações são pertinentes, mas o que se pode concluir é que, conquanto seja possível estabelecer distinções com base nos critérios expressamente mencionados no art. $3^{\circ}$, IV da $\mathrm{CF}$, esses critérios são mais "suspeitos" que os demais ${ }^{313}$.

C. Mello já demonstrou que o critério para se aferir a constitucionalidade de tratamentos jurídicos diferenciados não reside no fator de diferenciação ${ }^{314}$. Neste trabalho, por todo o exposto, sugere-se que apenas o exame da proporcionalidade pode trazer uma resposta coerente quanto à constitucionalidade de tratamentos jurídicos diferenciados base das medidas de ação afirmativa. Na verdade, não existe uma proibição definitiva para o estabelecimento de tratamentos jurídicos diferenciados com base nos critérios raça ou cor, mas o fato é que são critérios que ensejam uma dúvida maior quanto a sua constitucionalidade:

En general, puede decirse que no existen presupuestos para que se produzca una restricción, tales como que los pares comparativos tengan una determinada calidad. Sin embargo, a fin de poder trabajar efectivamente con los casos, pueden hacerse otras consideraciones atinentes a la posibilidad de restringirse a los pares

\footnotetext{
313 "Race clearly ought to remain a suspect classification in politics as well as law." FisCUS, Ronald Jerry. The Constitutional Logic of Affirmative Action. Durham: Duke University Press, 1992, p. 79. Nos Estados Unidos, o critério racial é tão suspeito que dá ensejo, inclusive, ao strict scrutiny, "[...] que é o standard mais exigente, em que há uma espécie de presunção de inconstitucionalidade da norma, que só cede quando se consegue detectar que o fato de desequiparação adotado foi talhado estritamente para a promoção de um interesse estatal de excepcional relevância." SARMENTO, Daniel. A igualdade étnico-racial no direito constitucional brasileiro: discriminação "de facto", teoria do impacto desproporcional e ação afirmativa. In: CAMARGO, Marcelo Novelino (Org.). Leituras complementares de direito constitucional: direitos humanos e direitos fundamentais. $3^{\text {a }}$ ed. Salvador: JusPodivm, 2008, p. 214. "Aí surge, no entanto, um dos grandes dilemas constitucionais de todo e qualquer programa tendente a pôr fim às diversas formas de discriminação, na medida em que agir 'positivamente' ou 'afirmativamente' significa, quase sempre, lançar mão de critérios e classificações consideradas 'suspeitas' por uma parcela considerável da doutrina e da jurisprudência de Direito Constitucional.” Gomes, Joaquim B. Barbosa. Ação afirmativa \& princípio constitucional da igualdade. Rio de Janeiro: Renovar, 2001, p. 77.
}

${ }^{314}$ Mello, Celso Antônio Bandeira de. O conteúdo jurídico do princípio da igualdade. $3^{\mathrm{a}}$ ed. São Paulo: Malheiros, 1998, p. 15. 
comparativos en los que se dude acerca de la constitucionalidad del trato diferenciado. ${ }^{315}$

Seguindo o caminho da common law, R. DWORKIN chega a conclusão semelhante:

\begin{abstract}
Pode-se dizer agora que essa distinção é muito sutil, e que se as classificações raciais foram e ainda podem ser usadas para propósitos malignos, todo o mundo tem um direito claro de que as classificações raciais não sejam usadas. Esse é o conhecido recurso à preguiçosa virtude da simplicidade. Supõe que se é difícil traçar uma linha ou que, se traçada, ela seria difícil de administrar, é prudente não tentar traçá-la. ${ }^{316}$
\end{abstract}

Não há uma proibição definitiva à utilização dos critérios de diferenciação arrolados no art. $3^{\circ}$, IV da CF, mas é possível dizer que são critérios que, por terem servido, durante muito tempo e em muitos lugares, de fatores de discriminação - inclusive discriminação fundada em leis -, dão origem a diferenciações de constitucionalidade "suspeita". Nesses casos, a análise da constitucionalidade deve ser mais rigorosa, como ocorre no strict scrutiny norte-americano: "[d]eve-se demonstrar não simplesmente que o uso dessa classificação não é irracional, mas que é 'necessário' para se obter o que o Supremo denominou um interesse governamental 'compulsório'[compelling governmental interests]."317

Por outro lado, é possível adotar o critério da raça ou cor como critério de diferenciação por uma simples questão de coerência: se se admite a constitucionalidade de dispositivos que estabelecem distinções com base em outros "critérios suspeitos", como a idade ou o gênero ${ }^{318}$, não há como se sustentar coerentemente que os "critérios suspeitos" da raça ou cor, por si só, não possam servir de fator de diferenciação. Não há, assim, uma proibição definitiva à utilização de tais critérios, mas uma proibição prima facie. Se, apesar

${ }^{315}$ Borowski, Martin. La estructura de los derechos fundamentales. Tradução Carlos Bernal Pulido. Bogotá: Universidad Externado de Colombia, 2003, p. 223.

${ }^{316}$ DwORKIN, Ronald. Uma questão de princípio. Tradução Luís Carlos Borges. São Paulo: Martins Fontes, 2000 , p. 450.

${ }^{317}$ DwORKIN, Ronald. Uma questão de princípio. Tradução Luís Carlos Borges. São Paulo: Martins Fontes, 2000 , p. 464.

318 Ninguém tem dúvidas quanto à constitucionalidade do atendimento prioritário a idosos estabelecido pela Lei $\mathrm{n}^{\circ} 10.048 / 00$, que traz distinção baseada no critério da idade. Quanto a distinções com base no gênero, há decisões monocráticas do STF as admitindo, a exemplo do RE 505.654/DF. No Superior Tribunal de Justiça vigora o entendimento segundo o qual o art. 100, I do Código de Processo Civil foi recepcionado pela CF (REsp 193.104/RS). Esse dispositivo considera competente o foro da residência da mulher nas ações de separação, conversão de separação em divórcio e anulação de casamento; em outras palavras, oferece benefícios processuais com base em uma distinção de gênero. 
da proibição prima facie de distinções de qualquer natureza e, em especial, com base no sexo, origem, raça, cor ou idade, pode-se efetuar distinções com base nesses elementos em alguns casos e mediante certas circunstâncias, significa dizer que a proibição pode ser sopesada e, portanto, configura um princípio. Desse modo, Allan Bakke ${ }^{319}$ e outros preteridos pelas medidas de ação afirmativa poderiam até ter um direito prima facie a que sua cor ou raça não fosse utilizada como critério de diferenciação, mas não teriam um direito definitivo a isso. Diante dessa situação, R. DwORKIN ironiza: “[...] não tem direito a uma vaga simplesmente porque elas são oferecidas a outros. $" 320$

Uma objeção que frequentemente é levantada quando se sugere a adoção do critério etnicorracial de diferenciação no Brasil consiste na impossibilidade de se determinar quais são os indivíduos pertencentes à etnia ou à raça beneficiada por conta da intensa miscigenação da população brasileira. Essa objeção, contudo, não é jurídica. Ao Direito importa saber se o critério etnicorracial é juridicamente possível e não se é social ou antropologicamente possível. De certa maneira, se o jurista é indagado sobre a possibilidade jurídica de algo, deve-se pressupor que é algo fisicamente possível: não faz sentido perguntar ao jurista se é possível adquirir a propriedade de uma nuvem por usucapião. Assim, este trabalho pressupõe que é possível distinguir pessoas pela raça ou cor - o próprio $\mathrm{STF}^{321}$ admite essa possibilidade -, o que faz sentido, pois, "[n]o Brasil, a discriminação racial é um fenômeno que tem a sua razão de ser no fenótipo do indivíduo, e não em sua cadeia de ancestralidade; costuma se afirmar que aqui se pratica o 'racismo de estampa', e ao invés do racismo de origem."322

No caso das distinções baseadas nos critérios raça ou cor, assim como nas distinções feitas com base em qualquer dos "critérios suspeitos", o ônus argumentativo de

${ }^{319}$ Cf. Seção 2.1 .

${ }^{320}$ DwORKIN, Ronald. Levando os direitos a sério. Tradução Nelson Boeira. São Paulo: Martins Fontes, 2002, p. 350.

321 “[...] 3. Raça humana. Subdivisão. Inexistência. Com a definição e o mapeamento do genoma humano, cientificamente não existem distinções entre os homens, seja pela segmentação da pele, formato dos olhos, altura, pêlos ou por quaisquer outras características físicas, visto que todos se qualificam como espécie humana. Não há diferenças biológicas entre os seres humanos. Na essência são todos iguais. 4. Raça e racismo. A divisão dos seres humanos em raças resulta de um processo de conteúdo meramente políticosocial. Desse pressuposto origina-se o racismo que, por sua vez, gera a discriminação e o preconceito segregacionista. [...]". RE 82.424.

${ }^{322}$ Informação verbal proferida por ADAMS, Luis Inácio Lucena. Supremo Tribunal Federal. Audiência Pública sobre a Constitucionalidade de Políticas de Ação Afirmativa de Acesso ao Ensino Superior. Brasília: 3 de março de 2010. Disponível em: <http://www.youtube.com/watch?v=lBfsV3tH0T0>. Acesso em: 7 de março de 2010. 
quem pretende estabelecer a distinção assume maior relevo. A fundamentação deve ser sólida: em razão da já abordada assimetria entre o princípio da igualdade jurídica e o princípio da igualdade fática, não basta um "empate".

Ademais, as medidas de ação afirmativa baseadas no critério etnicorracial não são uma prática corrente no Brasil. Ao contrário, são medidas novas que implicam mudanças de paradigmas e de práticas já consolidadas. Torna-se necessário, assim, demonstrar que há uma razão suficiente não apenas para o tratamento jurídico diferenciado, mas também para a mudança de uma prática consolidada. Nesse ponto, é possível mencionar o "princípio”,323 da inércia de C. PERELMAN:

\begin{abstract}
O princípio da inércia afirma que uma opinião que foi aceita no passado não deves [sic] ser abandonada outra vez sem haver razão suficiente. Assim sendo, ele tem o caráter de uma regra encarregada da argumentação ou da prova: o apelo a uma prática já existente não requer justificação, "somente a mudança tem de ser justificada". ${ }^{324}$
\end{abstract}

Assim, há um "duplo" ônus argumentativo para quem pretende estabelecer distinções com base no recorte etnicorracial: o ônus decorrente da relação assimétrica entre o princípio da igualdade jurídica e o princípio da igualdade fática e o ônus decorrente da mudança de práticas já consolidadas. O "duplo" ônus não é, contudo, insuperável, sendo possível demonstrar a proporcionalidade, caso a caso, de medidas de ação afirmativa baseadas no critério etnicorracial.

Primeiramente, deve-se tratar da adequação de tais medidas. Devem fomentar ou promover objetivos constitucionalmente previstos. No caso das medidas de ação afirmativa baseadas no critério etnicorracial, tal objetivo consiste essencialmente no fomento ao princípio da igualdade fática, facilitando o acesso de minorias a bens sociais escassos. Não é exagero também ressaltar que "erradicar a pobreza e a marginalização e reduzir as desigualdades sociais e regionais" são objetivos da República (art. 3º, III da CF). São medidas que visam a atacar desigualdades fáticas específicas entre grupos etnicorraciais, em especial entre brancos e negros:

\footnotetext{
${ }^{323}$ A palavra "princípio", aqui, também não se refere ao conceito de princípios enquanto mandamento de otimização, conforme a distinção feita neste trabalho, mas é questão de distribuição de ônus argumentativo.

${ }^{324}$ AlEXY, Robert. Teoria da argumentação jurídica. Tradução Zilda Hutchinson Schild Silva. São Paulo: Landy, 2001, p. 140.
} 
Em um país em que os negros são 64\% dos pobres e 69\% dos indigentes (dados do IPEA), em que o índice de desenvolvimento humano geral (IDH, 2000) figura o país em $74^{\circ}$ lugar, mas que, sob o recorte étnico-racial, o IDH relativo à população negra indica a $108^{\mathrm{a}}$ posição (enquanto o IDH relativo à população branca indica a $43^{\mathrm{a}}$ posição), faz-se necessária a adoção de ações afirmativas em benefício da população negra, em especial nas áreas da educação e do trabalho. $^{325}$

Deve-se demonstrar que a adoção das medidas de ação afirmativa propostas, de fato, contribuirá para o fomento do princípio da igualdade fática. Por exemplo, se medidas de ação afirmativa baseadas no critério etnicorracial que estabelecem reserva de vagas a pessoas negras e pardas em universidades públicas fomentarão o princípio da igualdade fática, cujo âmbito de proteção amplo abrange a igualdade de acesso à educação superior entre os diferentes grupos etnicorraciais. As experiências de outros países nesse campo, em geral bem sucedidas ${ }^{326}$, podem trazer elementos interessantes para o exame da adequação.

Seguindo-se adiante, deve-se passar ao exame da necessidade da medida de ação afirmativa analisada. Em outras palavras, deve-se averiguar se há outras medidas que fomentem o mesmo objetivo em igual ou maior intensidade, mas que restrinjam menos os princípios com os quais colide. Esse ponto parece ser bastante polêmico no caso das medidas de ação afirmativa baseadas no critério etnicorracial. Como informa K. MUNANGA $^{327}$, há quem sustente que políticas universalistas fomentarão a igualdade fática entre grupos etnicorraciais e não ensejarão qualquer vulneração ao princípio da igualdade jurídica. Se a premissa fosse verdadeira, seria forçoso concluir que as medidas de ação afirmativa baseadas no critério etnicorracial não são necessárias. Contudo, há dados que ilustram que as medidas universalistas são pouco eficazes na redução das desigualdades entre grupos etnicorraciais no Brasil:

\footnotetext{
${ }^{325}$ PIOVESAN, Flávia. Implementação do direito à igualdade racial. Revista de Direitos Difusos, [S.1.], v. 9, p. 1123-1131, out. 2001, p. 1130. A título de curiosidade, segundo o relatório de desenvolvimento humano de 2000, a $43^{\mathrm{a}}$ posição era ocupada pela Hungria, e a $108^{\mathrm{a}}$ posição, pelo Vietnã. Cf. UNITED NATIONS Development Programme. Human Development Report 2000. New York: Oxford University Press, 2000, p. 157-159).

${ }^{326}$ Cf. MunAngA, Kabengele. Políticas de ação afirmativa em benefício da população negra no Brasil: um ponto de vista em defesa de cotas. In: SILVA, Petronilha Beatriz Gonçalves e, SILVÉRIO, Valter Roberto (Org.). Educação e ações afirmativas: entre a injustiça simbólica e a injustiça econômica. Brasília: Instituto Nacional de Estudos e Pesquisas Educacionais Anísio Teixeira, 2003, p. 118.

${ }^{327}$ Cf. Munanga, Kabengele. Políticas de ação afirmativa em benefício da população negra no Brasil: um ponto de vista em defesa de cotas. In: Silva, Petronilha Beatriz Gonçalves e, SILVÉRIO, Valter Roberto (Org.). Educação e ações afirmativas: entre a injustiça simbólica e a injustiça econômica. Brasília: Instituto Nacional de Estudos e Pesquisas Educacionais Anísio Teixeira, 2003, p. 119.
} 
De acordo com análises do Instituto de Pesquisa Econômica Aplicada, baseadas nas PNADs de 2001 a 2007, há reduções nas taxas de analfabetismo de mulheres e homens negros e brancos e aumento na média de anos de estudo.

No entanto, as distâncias entre os indicadores dos distintos grupos permanecem, revelando a manutenção das desigualdades raciais. ${ }^{328}$

As políticas universalistas têm, na verdade, outra finalidade. No caso da educação, é inegável que essas políticas aperfeiçoam o nível educacional em geral, mas mantêm ou pouco reduzem o fosso que separa certos grupos etnicorraciais no país. A finalidade das políticas de ação afirmativa calcadas no critério etnicorracial é outra: fomentar a igualdade fática entre grupos etnicorraciais. Também é finalidade distinta daquela que orienta as medidas de ação afirmativa baseadas em critérios socioeconômicos, que é o fomento da igualdade fática entre grupos socioeconômicos ${ }^{329}$ - os pares de comparação são distintos:

\begin{abstract}
Ademais, discriminação racial e pobreza nem sempre se confundem. Os dados estatísticos, compilados no presente estudo, demonstram que a existência do discrímen racial, muitas vezes, independe da condição socioeconômica do indivíduo, a exemplo dos índices referentes a emprego e escolaridade. Isto, sem mencionar a extrema defasagem da presença negra nos campus [sic] universitários, como também demonstrado. ${ }^{330}$
\end{abstract}

De fato, os programas de ação afirmativa "[...] usam medidas vigorosas porque as mais suaves fracassarão [...]"331. Usam medidas vigorosas porque, se usassem as menos vigorosas, possivelmente não seriam medidas necessárias, pois seria mais fácil cogitar outros meios de se fomentar em igual ou maior intensidade os mesmos objetivos com menores vulnerações ao princípio da igualdade jurídica ou, eventualmente, a outros princípios.

Por tratarem das condições fáticas existentes para a realização dos princípios, no exame da adequação e da necessidade das medidas de ação afirmativa que se utilizam do critério etnicorracial não se faz necessária uma certeza absoluta de que realmente fomentarão - em que grau fomentarão - o princípio da igualdade fática ou outros

${ }^{328}$ POIRIER, Marie-Pierre. Ações afirmativas e avanços sociais. Folha de S. Paulo, São Paulo, 4 abr. 2010. Caderno Brasil, p. 3.

${ }^{329}$ Cf. GUERRINI, Estela Waksberg. Ações afirmativas para negros nas universidades públicas brasileiras: o caso do Tribunal de Justiça do Rio de Janeiro (2001-2008). Dissertação (mestrado em Direito), Faculdade de Direito, Universidade de São Paulo, São Paulo, 2009, p. 30.

${ }^{330}$ Silva, Sidney Pessoa Madruga da. Discriminação Positiva: Ações Afirmativas na Realidade Brasileira. Brasília: Brasília Jurídica, 2005, p. 249.

331 DwORKIN, Ronald. Uma questão de princípio. Tradução Luís Carlos Borges. São Paulo: Martins Fontes, 2000, p. 439. 
objetivos. Como já afirmado, a exigência de certeza nas prognoses empíricas imobilizaria o legislador $^{332}$. Basta que seja provável - ou altamente provável - que as medidas de ação afirmativa servirão, com certa intensidade, para a redução da desigualdade fática entre os grupos etnicorraciais. Um exemplo se encontra na alta probabilidade de que a facilitação do acesso ao ensino superior a grupos minoritários incrementarão não apenas a igualdade de educação, mas, posteriormente, a igualdade econômica entre grupos etnicorraciais, além de combater a discriminação racial pelo convívio entre esses grupos.

Por fim, se superados os demais elementos, deve-se examinar a proporcionalidade em sentido estrito da medida de ação afirmativa analisada. Ressalta-se novamente que não se trata de uma mera comparação entre, de um lado, o grau de satisfação de alguns princípios e, de outro, o grau de vulneração de outros princípios. É uma comparação discursivamente correta, averiguando-se se a importância do cumprimento do princípio em sentido contrário justifica o prejuízo ou não-cumprimento do outro.

Quanto à proporcionalidade em sentido estrito, convém relembrar que as escalações são relativamente rudes. Seguindo-se as regras pragmáticas do discurso, certo é não se chagar sempre a uma certeza conclusiva, mas a uma resposta racional, que, aliás, nem “[...] se relaciona com o fato de a afirmação normativa em questão ser ou não absolutamente racional, mas antes se pode ser racionalmente justificada no contexto da ordem jurídica em vigor. ${ }^{, 333}$ No Brasil, um bom caminho em direção ao discurso ideal já é estabelecido com as constantes discussões sobre a adoção de medidas de ação afirmativa baseadas no critério etnicorracial. O próprio STF, com a recente audiência pública sobre a constitucionalidade de políticas de ação afirmativa de acesso ao ensino superior ${ }^{334}$, demonstrou que busca se aproximar do ideal discursivo ao permitir a argumentação proveniente de diversos setores da sociedade - inclusive daqueles setores que dessas políticas mais necessitam -,

\footnotetext{
332 Cf. AleXY, Robert. Constitucionalismo Discursivo. $2^{\mathrm{a}}$ ed. Tradução Luís Afonso Heck. Porto Alegre: Livraria do Advogado, 2008, p. 13.

333 ALEXY, Robert. Teoria da argumentação jurídica. Tradução Zilda Hutchinson Schild Silva. São Paulo: Landy, 2001, p. 269.

334 A audiência pública sobre a constitucionalidade de políticas de ação afirmativa de acesso ao ensino superior foi convocada pelo Ministro Enrique Ricardo Lewandowski, relator da ADPF 186 e do RE 597.285/RS. Realizada nos dias 3, 4 e 5 de março de 2010, foi televisionada e contou com a presença de inúmeras autoridades acadêmicas e de representantes de diversos setores sociais que puderam expor livremente aos julgadores seus pontos de vista a respeito do tema.
} 
conferindo maior legitimidade a sua futura decisão que deve almejar ser "“[...] reconhecida pelos cidadãos em discussão e reflexão crítica como sua própria." ${ }^{\text {‘35. }}$

\begin{abstract}
O valor prático da teoria do discurso só se mostra em toda sua envergadura quando é transformada numa teoria básica das instituições da constituição democrática abordada na discussão, portanto, no contexto de uma teoria do Estado e do Direito. ${ }^{336}$
\end{abstract}

Uma observação final: não é o objetivo desta seção - nem deste trabalho - defender que um critério de diferenciação seja melhor que outro para a redução de certas desigualdades. O objetivo é deixar claro que qualquer critério é, em tese, juridicamente possível. É juridicamente possível a adoção de medidas de ação afirmativa que se baseiam exclusivamente no critério etnicorracial, se proporcionais, mesmo que não seja o "melhor" critério para se atingir determinado fim. Juridicamente não faz sentido, por exemplo, sustentar que os programas de ação afirmativa sob o critério etnicorracial "[...] não estariam utilizando os critérios mais adequados, porque estariam elegendo apenas o critério racial $[\ldots]]^{, 337}$, pois "[...] um tratamento desigual não deixa de ser arbitrário somente quando é a melhor ou a mais justa solução; ele já o deixa de ser se para sua admissibilidade há razões plausíveis." ${ }^{338}$ Se for escolhido o critério etnicorracial, o foro de discussão quanto a sua pertinência é na esfera política, e não na esfera jurídica, na qual só cabe discutir a proporcionalidade da medida. Políticas boas não se confundem com políticas válidas. Ademais, quem defende que a conjugação de critérios etnicorraciais com critérios socioeconômicos deva ser adotada para a redução das desigualdades entre os diferentes grupos etnicorraciais precisa ter em mente que, do outro lado, se operará uma restrição ainda maior ao princípio da igualdade jurídica: um branco rico, por exemplo, terá seu direito prima facie à igualdade jurídica restringido duplamente - por sua raça e por sua posição socioeconômica -, o que exige uma fundamentação ainda mais rigorosa.

\footnotetext{
335 AleXY, Robert. Constitucionalismo Discursivo. $2^{\mathrm{a}}$ ed. Tradução Luís Afonso Heck. Porto Alegre: Livraria do Advogado, 2008, p. 36.

336 ALEXY, Robert. Teoria da argumentação jurídica. Tradução Zilda Hutchinson Schild Silva. São Paulo: Landy, 2001, p. 312.

337 KaUfmann, Roberta Fragoso Menezes. Ações afirmativas à brasileira: necessidade ou mito? Porto Alegre: Livraria do Advogado, 2007, p. 271.

338 AlEXY, Robert. Teoria dos direitos fundamentais. Tradução Virgílio Afonso da Silva. São Paulo: Malheiros, 2008, p. 413.
} 
Fica, como conclusão desta seção, a importante noção de que, mesmo à luz da teoria dos princípios - que é a mais exigente quanto à fundamentação das restrições a princípios constitucionais -, o critério etnicorracial de diferenciação não é definitivamente proibido ainda que utilizado isoladamente. Por conseguinte, medidas de ação afirmativa baseadas nesse critério também não o são. $\mathrm{Na}$ análise casuística, é perfeitamente possível encontrar elementos fundamentadores desse gênero de política pública a sustentar materialmente a vulneração que se opera no princípio da igualdade jurídica ou em outros princípios constitucionalmente relevantes. 


\section{CONCLUSÃO}

"A melhor abordagem seria aquela que combina a aceitação da identidade humana genérica com a aceitação da identidade da diferença."

Kabengele Munanga

No estudo que ora se conclui, procurou-se delinear um modelo para a compreensão da possibilidade jurídica da adoção de medidas de ação afirmativa. Não se trata de um modelo único, muito menos definitivo, para a compreensão do tema: seria mais sugestão de um caminho coerente a ser seguido na análise jurídica das medidas de ação afirmativa, evitando-se os caminhos tortuosos da subjetividade e da intuição.

Percebeu-se que as medidas de ação afirmativa são, por sua própria natureza, medidas restritivas de direitos fundamentais, mas, por outro lado, também são formas de realização de direitos fundamentais. São medidas que se baseiam, por definição, no estabelecimento de tratamentos jurídicos desiguais e, portanto, vulneram o princípio da igualdade jurídica. Essa vulneração jamais seria legítima se não houvesse fundamentos constitucionais para tanto; na verdade, o próprio princípio da igualdade fática serve de sustentação material para o tratamento diferenciado estabelecido pelas medidas de ação afirmativa, que podem se servir, ainda, a depender do caso, de outros fundamentos contidos na CF.

Restrições a direitos fundamentais com a estrutura de princípio não são apenas possíveis, mas são comuns e frequentes. O mesmo se aplica ao princípio da igualdade jurídica. Tratamentos juridicamente desiguais são, desse modo, possíveis, ainda que seja ordenado o tratamento jurídico igual caso não haja razões suficientes que justifiquem o tratamento jurídico desigual.

Percebeu-se, ainda, que o critério de diferenciação, tomado isoladamente, é irrelevante para se aferir a constitucionalidade de tratamentos jurídicos desiguais. Qualquer critério pode ser, em tese, adotado, inclusive os critérios “suspeitos" elencados no art. $3^{\circ}$, 
IV da CF. A constitucionalidade do tratamento jurídico diferenciado só pode ser aferida mediante o exame da proporcionalidade em sentido amplo nos moldes apresentados neste estudo, que é a forma de resolução de colisões entre princípios. Essa aferição, portanto, só pode se dar no caso concreto.

Passa-se, agora, à confirmação das hipóteses iniciais que nortearam o estudo:

(i) As políticas de ação afirmativa estão fundamentadas em princípios contidos na CF (em especial no princípio da igualdade fática): as medidas de ação afirmativa operam mediante o estabelecimento de tratamentos jurídicos diferenciados de modo a fomentar o princípio da igualdade fática; ademais, outros princípios constitucionais também podem servir, conjuntamente, de fundamentos para medidas de ação afirmativa específicas.

(ii) As políticas de ação afirmativa, para serem constitucionais, devem ser proporcionais, pois restringem direitos: mediante o estabelecimento de medidas de ação afirmativa ocorrerão necessariamente vulnerações ao princípio da igualdade jurídica podem, eventualmente, ocorrer vulnerações também a outros princípios -; se a vulneração for proporcional, contudo, será constitucional ${ }^{339}$, ou seja, será uma restrição e não uma violação aos direitos fundamentais com a estrutura de princípio atingidos.

(iii) As políticas de ação afirmativa, em geral, são um meio facultativo para fomentar a realização de princípios constitucionais (em especial o princípio da igualdade fática), mas não são um meio obrigatório nem proibido: embora seja possível identificar excepcionais medidas de ação afirmativa obrigatórias de acordo com a $\mathrm{CF}$, esse gênero de políticas públicas é, em geral, um instrumento facultado ao Estado; apenas o exame da proporcionalidade em sentido amplo poderá definir os limites entre o facultado e o proibido.

(iv) A adoção (ou não) de políticas de ação afirmativa, se facultativas, é uma questão política, não encontrando respaldo jurídico apenas se as medidas forem desproporcionais: de acordo com o ordenamento constitucional brasileiro, percebe-se que há ampla liberdade de eleição de meios para se atingir os objetivos constitucionalmente determinados (espaços estruturais) e não há qualquer vedação geral para a adoção de medidas de ação afirmativa; a eleição de meios é uma questão política e só será juridicamente inaceitável se desproporcional.

\footnotetext{
339 “[...] intervir em um direito fundamental não é, por si só, algo constitucionalmente vedado; decisivo para se saber se a intervenção é constitucionalmente justificável é a análise dos princípios em colisão e das circunstâncias do caso concreto." SILVA, Virgilio Afonso da. Direitos fundamentais: conteúdo essencial, restrições e eficácia. $2^{\mathrm{a}}$ ed. São Paulo: Malheiros, 2010, p. 119.
} 
(v) O ônus argumentativo é de quem pretende o estabelecimento de políticas de ação afirmativa: por conta da assimetria entre o princípio da igualdade fática e o princípio da igualdade jurídica, o tratamento jurídico igual é ordenado se não houver razões suficientes para um tratamento jurídico desigual; não se trata, contudo, de uma relação incondicionada de precedência, mas apenas de uma questão de distribuição de ônus argumentativo decorrente da própria racionalidade do discurso.

(vi) Os argumentos empíricos (sociológicos, econômicos, culturais, etc.), geralmente oriundos de fora do círculo jurídico, são, nesse caso, de particular interesse: a argumentação jurídica, em especial nos "casos difíceis", não se resume a argumentos dogmáticos, mas absorve argumentos práticos gerais, inclusive empíricos; “[q]uando, e isso não é raro, não há disputas sobre (1) [o estado de coisas prescrito], a decisão depende unicamente de argumentos empíricos. Isso exemplifica a considerável importância da argumentação empírica no discurso jurídico."340

Neste trabalho, o que se procurou, acima de tudo, foi delinear um instrumento útil. Que seja útil tanto para o jurista, na elaboração de seus juízos sobre a constitucionalidade de medidas de ação afirmativa que se lhe apresentam, quanto para os não juristas, para que, ao desenvolverem estudos sobre medidas de ação afirmativa ou atuarem politicamente a favor ou contra a adoção de tais medidas, possam entender de que forma suas conclusões contribuem para a argumentação na área do Direito. Esse é o desejo do autor.

\footnotetext{
${ }^{340}$ ALEXY, Robert. Teoria da argumentação jurídica. Tradução Zilda Hutchinson Schild Silva. São Paulo: Landy, 2001, p. 234.
} 


\section{REFERÊNCIAS}

AARNIO, Aulis. La tesis de la única respuesta correcta y el principio regulativo del razonamiento jurídico. Tradução Josep Aguiló Regla. Doxa: cuadernos de filosofía del derecho, Alicante, n. 8, p. 23-38, 1990.

Agrawal, Purushottam. En Inde, des quotas pour les basses castes. Le Monde diplomatique, Paris, a. 54, n. 638, p. 12-13, mai 2007.

Aleinikoff, Thomas Alexander. Constitutional Law in the Age of Balancing. The Yale Law Journal, New Haven, v. 96, n. 5, p. 943-1005, Apr. 1987.

ALEXY, Robert. Sistema jurídico, principios jurídicos y razón práctica. Tradução Manuel Atienza. Doxa: cuadernos de filosofía del derecho, Alicante, n. 5, p. 139-151, 1988.

Derechos, razonamiento jurídico y discurso racional. Tradução Pablo Larrañaga. Isonomía, México, n. 1, p. 37-49, oct. 1994.

. Jurgen Habermas's theory of legal discourse. Cardozo Law Review, New York, v. 17, p. 1027-1034, Mar. 1996.

35,1999 .

La tesis del caso especial. Tradução Isabel Lifante. Isegoría, Madrid, n. 21, p. 23-

. Direitos fundamentais no estado constitucional democrático. Tradução Luís Afonso Heck. Revista de direito administrativo, Rio de Janeiro, n. 217, p. 55-79, jul./set. 1999.

; Bulygin, Eugenio. La pretensión de corrección del derecho: la polémica sobre la relación entre derecho y moral. Tradução Paula Gaido. Bogotá: Universidad Externado de Colombia, 2001.

. Teoria da argumentação jurídica. Tradução Zilda Hutchinson Schild Silva. São Paulo: Landy, 2001. 
Justicia como corrección. Tradução Ana Inés Haquín. Doxa: cuadernos de filosofía del derecho, Alicante, n. 26, p. 161-173, 2003.

. Tres escritos sobre los derechos fundamentales y la teoría de los principios. Tradução Carlos Bernal Pulido. Bogotá: Universidad Externado de Colombia, 2003.

On Balancing and Subsumption: a Structural Comparison. Ratio Juris, Malden, v. $\overline{16, \text { n. } 4}$, p. 433-449, Dec. 2003. $\overline{\text { Gedisa, }} 2004$.

. El concepto y la validez del derecho. $2^{\mathrm{a}}$ ed. Tradução Jorge Seña. Barcelona: . Sobre as Estruturas dos Princípios Jurídicos. Tradução Fernando Alves Gomes e Luiz Gonzaga Guimarães e Garcia de Carvalho. Revista Internacional de Direito Tributário, Belo Horizonte, v. 3, p. 155-167, jan./jun. 2005.

. Teoría del discurso y derechos humanos. Tradução Luis Villar Borda. Bogotá: Universidad Externado de Colombia, 2005.

. Discourse Theory and Fundamental Rights. In: MENÉNDEZ, Augustín José; ERIKSEN, Erik Oddvar (Edit.). Arguing Fundamental Rights. Dordrecht: Springer, 2006. p. $15-29$.

. Ponderación, control de constitucionalidad y representación. Tradução René de la Vega. In:___ _ IBÁÑEZ, Perfecto Andrés. Jueces y ponderación argumentativa. México: Universidad Nacional Autónoma de México, 2006.

. Teoria dos direitos fundamentais. Tradução Virgílio Afonso da Silva. São Paulo: Malheiros, 2008.

. Constitucionalismo Discursivo. $2^{\mathrm{a}}$ ed. Tradução Luís Afonso Heck. Porto Alegre: Livraria do Advogado, 2008.

. Direito, Razão, Discurso: Estudos para a filosofia do direito. Tradução Luís Afonso Heck. Porto Alegre: Livraria do Advogado, 2010. 
Alves, José Augusto Lindgren. Diferencialismo e igualitarismo na luta contra a discriminação racial. Revista USP, São Paulo, n. 69, p. 14-25, mar./mai. 2006.

AtChabahian, Serge. Princípio da igualdade e ações afirmativas. São Paulo: RCS, 2004.

Avi-YonaH, Reuven. Os Três Objetivos da Tributação. Tradução Luís Flávio Neto. In: Costa, Alcides Jorge (Org.). Direito Tributário Atual, v. 22. São Paulo: Dialética, 2008.

ÁvilA, Humberto. A distinção entre princípios e regras e a redefinição do dever de proporcionalidade. Revista Diálogo Jurídico, Salvador, a. 1., n. 4, jul. 2001. Disponível em: <http://www.direitopublico.com.br/pdf_4/DIALOGO-JURIDICO-04-JULHO-2001HUMBERTO-AVILA.pdf $>$. Acesso em: 29 de outubro de 2009.

. "Neoconstitucionalismo": entre a "ciência do direito" e o "direito da ciência". Revista Eletrônica de Direito do Estado, Salvador, n. 17, jan./mar. 2009. Disponível em: $<$ http://www.direitodoestado.com.br/rede/edicao/17>. Acesso em: 28 de outubro de 2009.

BALIBAR, Etienne. Le mot race n'est pas "de trop" dans la Constitution française. Mots: les langages du politique, Paris, v.33, n. 1, p. 241-256, 1992.

BArcellos, Ana Paula de. Neoconstitucionalismo, direitos fundamentais e controle das políticas públicas. In: CAMARGO, Marcelo Novelino (Org.). Leituras complementares de direito constitucional: direitos humanos e direitos fundamentais. $3^{\text {a }}$ ed. Salvador: JusPodivm, 2008.

BARreto, Paulo Ayres. Contribuições: regime jurídico, destinação e controle. São Paulo: Noeses, 2008.

Bastos, Celso Ribeiro. Curso de Direito Constitucional. São Paulo: Celso Bastos Editora, 2002

Belmonte, Cláudio Petrini. O sentido e o alcance do princípio da igualdade como meio de controle da constitucionalidade das normas jurídicas na jurisprudência do Tribunal Constitucional de Portugal e do Supremo Tribunal Federal do Brasil. Revista de Informação Legislativa, Brasília, a. 36, n. 144, p. 157-175, out./dez. 1999.

Berlin, Isaiah. Equality. Proceedings of the Aristotelian Society, London, new series v. 56, p. 301-326, 1955/1956. 
BÖCKENFÖRDE, Ernst-Wolfgang. Escritos sobre Derechos Fundamentales. Tradução Juan Luis Requejo Pagés e Ignacio Villaverde Menéndez. Baden-Baden: Nomos, 1993.

BorowsKI, Martin. La restricción de los derechos fundamentales. Tradução Rodolfo Arango. Revista Española de Derecho Constitucional, Madrid, a. 20, n. 59, p. 29-56, mayo/agosto 2000.

. La estructura de los derechos fundamentales. Tradução Carlos Bernal Pulido. Bogotá: Universidad Externado de Colombia, 2003.

Bossuyt, Marc. Prevention of discrimination: the concept and practice of affirmative action. Relatório final apresentado à comissão de Direitos Humanos do Conselho Econômico e Social das Nações Unidas. New York: ECOSOC, 2002.

Calves, Gwénaële. Égalité (Principe d'). In: Chagnollaud, Dominique ; Drago, Guillaume (Dir.). Dictionnaire des droits fondamentaux. Paris: Dalloz, 2006. p. 373-383. 2008.

. La discrimination positive. $2^{\text {ème }}$ edition. Paris: Presses Universitaires de France,

Canotilho, José Joaquim Gomes. Direito Constitucional e Teoria da Constituição. $7^{\mathrm{a}}$ ed. Coimbra: Almedina, 2003.

CARIGNAN, Pierre. L'égalité dans le droit: une méthode d'approche appliquée à l'article 10 de la Charte des droits et libertés de la personne. Revue Juridique Thémis, Montréal, v. 21, p. 491-539, 1987.

CARVAlho, José Jorge de. Inclusão Étnica e Racial no Brasil: a questão das cotas no ensino superior. São Paulo: Attar, 2005.

Carvalho, Paulo de Barros. Curso de Direito Tributário. 17 a ed. São Paulo: Saraiva, 2005.

. Direito Tributário, Linguagem e Método. $3^{\mathrm{a}}$ ed. São Paulo: Noeses, 2009.

COELHO, Inocêncio Mártires. As idéias de Peter Häberle e a abertura da interpretação constitucional no direito brasileiro. Revista de Informação Legislativa, Brasília, a. 35, n. 137, p. 155-164, jan./mar. 1998. 
Konrad Hesse/Peter Häberle: um retorno aos fatores reais de poder. Revista de Informação Legislativa, Brasília, a. 35, n. 138, p. 185-191, abr./jun. 1998.

COMPARATO, Fábio Konder. Igualdade, desigualdades. Revista trimestral de direito público, São Paulo, n. 1, p. 69-78, 1993.

. Precisões sobre os conceitos de lei e de igualdade jurídica. Revista dos Tribunais, São Paulo, a. 87, n. 750, p. 11-19, abr. 1998.

. A afirmação histórica dos direitos humanos. $2^{\mathrm{a}}$ ed. São Paulo: Saraiva, 2001.

CoRLeTt, J. Angelo. Race, Rights and Justice. [Dordrecht]: Springer, 2009.

DwORKIN, Ronald. Social Sciences and Constitutional Rights - The Consequences of Uncertainty. Journal of Law and Education, Baltimore, v. 6, n. 1, p. 3-12, Jan. 1977.

. No right answer? New York University Law Review, New York, v. 53, n. 1, p. 132, Apr. 1978.

. Uma questão de princípio. Tradução Luís Carlos Borges. São Paulo: Martins Fontes, 2000.

2002. . Levando os direitos a sério. Tradução Nelson Boeira. São Paulo: Martins Fontes,

. A virtude soberana: a teoria e a prática da igualdade. Tradução Jussara Simões. São Paulo: Martins Fontes, 2005.

ERBEL, Günter. Inhalt und Auswirkungen der verfassungsrechtlichen Kunstfreiheitsgarantie. Berlin: Springer, 1996.

ERIKSEN, Erik Oddvar. Democratic or Jurist-Made Law. In: MenÉndez, Augustín José; (Edit.). Arguing Fundamental Rights. Dordrecht: Springer, 2006. p. 69-99.

FERRAZ JR., Tercio Sampaio. Introdução ao estudo do direito: técnica, decisão, dominação. $4^{\mathrm{a}}$ ed. São Paulo: Atlas, 2003. 
FischMANN, Roseli. Educação, democracia e a questão dos valores culturais. In: Munanga, Kabengele (Org.). Estratégias e Políticas de Combate à Discriminação Racial. São Paulo: Editora da Universidade de São Paulo, 1996. p. 177-194.

FISCUS, Ronald Jerry. The Constitutional Logic of Affirmative Action. Durham: Duke University Press, 1992.

FORSTHOFF, Ernst. El Estado de la sociedad industrial. Tradução Luis López Guerra e Jaime Nicolás Muñiz. Madrid: Instituto de Estudios Políticos, 1975.

FrisCHEISEN, Luiza Cristina Fonseca. As idéias viajantes: igualdade formal e igualdade material. Boletim Científico - Escola Superior do Ministério Público da União, Brasília, a. 1, n. 3, p. 55-62, abr./jun. 2002.

FRY, Peter. A persistência da raça: ensaios antropológicos sobre o Brasil e a África austral. Rio de Janeiro: Civilização Brasileira, 2005.

Galuppo, Marcelo Campos; BAsile, Rafael Faria. O princípio jurídico da igualdade e a ação afirmativa étnico-racial no Estado Democrático de Direito: o problema das cotas. Revista de Informação Legislativa, Brasília, a. 43, n. 172, p. 99-108, out./dez. 2006.

GARCíA, Juan Carlos Utrera. Apuntes sobre la teoría de los derechos fundamentales de R. Alexy. Revista derechos y libertades: Revista del Instituto Bartolomé de las Casas, Madrid, a. 2, n. 4, p. 355-379, 1995.

Gomes, Joaquim B. Barbosa. A recepção do instituto da ação afirmativa pelo Direito Constitucional Brasileiro. Revista de Informação Legislativa, Brasília, a. 38, n. 151, p. 129-151, jul./set. 2001.

Renovar, 2001.

Ação afirmativa \& princípio constitucional da igualdade. Rio de Janeiro: O debate constitucional sobre as ações afirmativas. Revista de Direitos Difusos,

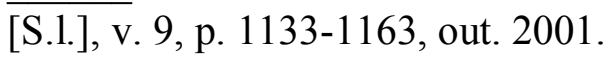

GUERRINI, Estela Waksberg. Ações afirmativas para negros nas universidades públicas brasileiras: o caso do Tribunal de Justiça do Rio de Janeiro (2001-2008). Dissertação (mestrado em Direito), Faculdade de Direito, Universidade de São Paulo, São Paulo, 2010. 
HÄBERLE, Peter. Hermenêutica Constitucional. Tradução Gilmar Ferreira Mendes. Porto Alegre: Sergio Antonio Fabris, 1997.

HABERMAS, Jürgen. Between Facts and Norms: contributions to a discourse theory of law and democracy. Tradução William Rehg. Cambridge: Massachusetts Institute of Technology Press, 1996.

HESSE, Konrad. A Força Normativa da Constituição. Tradução Gilmar Ferreira Mendes. Porto Alegre: Sergio Antonio Fabris, 1991.

- Elementos de Direito Constitucional da República Federal da Alemanha. Tradução Luís Afonso Heck. Porto Alegre: Sergio Antonio Fabris, 1998.

JONES, Jeffrey M. Race, Ideology and Support for Affirmative Action. [S.1.]: Gallup, 2005. Disponível em: <http://www.gallup.com/poll/18091/race-ideology-support-affirmativeaction.aspx $>$. Acesso em 22 de dezembro de 2009.

KARST, Kenneth L.; Horowitz, Harold W. Affirmative action and equal protection. Virginia Law Review, Charlottesville, v. 60, p. 955-974, 1974.

Kaufmann, Roberta Fragoso Menezes. Ações afirmativas à brasileira: necessidade ou mito? Porto Alegre: Livraria do Advogado, 2007.

Kellough, J. Edward. Understanding Affirmative Action: politics, discrimination and the search for justice. Washington: Georgetown University Press, 2006.

Kumm, Mattias. Who's Afraid of the Total Constitution? In: MenÉndeZ, Augustín José; ERIKSEN, Erik Oddvar (Edit.). Arguing Fundamental Rights. Dordrecht: Springer, 2006. p. 113-140.

LiMA, George Marmelstein. Alexy à Brasileira ou a Teoria da Katchanga. Direitos Fundamentais, [S.1.], 2008. Disponível em <http://direitosfundamentais.net/2008/09/18/ alexy-a-brasileira-ou-a-teoria-da-katchanga/>. Acesso em 23 de setembro de 2009.

LOCHAK, Danièle. La race: une catégorie juridique? Mots: les langages du politique, Paris, v.33, n. 1, p. 291-303, 1992. 
LOPES, José Reinaldo de Lima. Direitos humanos e tratamento igualitário: questões de impunidade, dignidade e liberdade. Revista brasileira de ciências sociais, São Paulo, v. 15, n. 42, p. 77-100, fev. 2000.

MANIACI, Giorgio. Algunas notas sobre coherencia y balance en la teoría de Robert Alexy. Tradução José Juan Moreso. Isonomía, México, n. 20, p. 137-177, abr. 2004.

Medeiros, Priscila Martins. "Raça” e Estado democrático: o debate sóciojurídico acerca das políticas de ação afirmativa no Brasil. Dissertação (mestrado em Sociologia), Centro de Educação e Ciências Humanas, Universidade Federal de São Carlos, São Carlos, 2005.

Mello, Celso Antônio Bandeira de. O conteúdo jurídico do princípio da igualdade. $3^{\mathrm{a}}$ ed. São Paulo: Malheiros, 1998.

. Curso de direito administrativo. 26a ed. São Paulo: Malheiros, 2009.

Mello, Marco Aurélio Mendes de Farias. Óptica constitucional - a igualdade e as ações afirmativas. Revista de Direito Bancário, do Mercado de Capitais e da Arbitragem, São Paulo, a. 5, n. 15, p. 13-20, jan./mar. 2002.

Melo, Monica de. O princípio da igualdade à luz das ações afirmativas: o enfoque da discriminação positiva. Cadernos de Direito Constitucional e Ciência Política, São Paulo, a. 6, n. 25, p. 79-101, out./dez. 1998.

MENDES, Gilmar Ferreira. O princípio da proporcionalidade na jurisprudência do Supremo Tribunal Federal: novas leituras. Revista Diálogo Jurídico, Salvador, a. 1., n. 5, ago. 2001. Disponível em: <http://www.direitopublico.com.br/pdf_5/DIALOGO-JURIDICO-05AGOSTO-2001-GILMAR-MENDES.pdf $>$. Acesso em: 29.10.2009.

MENÉNDEZ, Augustín José; ERIKSEN, Erik Oddvar. Introduction. In: (Edit.). Arguing Fundamental Rights. Dordrecht: Springer, 2006. p. 1-12.

MENEZES, Paulo. Ação afirmativa (affirmative action) no direito norte-americano. São Paulo: Revista dos Tribunais, 2001.

MesA, Gloria Patricia Lopera. Los derechos fundamentales como mandatos de optimización. Doxa: Cuadernos de Filosofía del Derecho, Alicante, n. 27, p. 211-243, 2004. 
MiLl, John Stuart. Utilitarianism. London: Parker, Son, and Bourn, West Strand, 1863.

MonoD, Jacques. $O$ acaso e a necessidade: ensaio sobre a filosofia natural da biologia moderna. Tradução Alice Sampaio. Mem Martins: Europa-América, 2002.

Montebello, Marianna. As Políticas de Ação Afirmativa sob a Perspectiva do Direito Internacional dos Direitos Humanos. Interesse Público, Porto Alegre, a. 6, n. 29, p. 117138, jan./fev. 2005.

MunANGA, Kabengele. Du blanchissement à la négritude: la dialectique de la question raciale au Brésil. Recherche, Pédagogie et Culture, [S.1.], n. 64, p. 20-25, oct./déc. 1983.

O anti-racismo no Brasil. In: (Org.). Estratégias e Políticas de Combate à Discriminação Racial. São Paulo: Editora da Universidade de São Paulo, 1996.

. Políticas de ação afirmativa em benefício da população negra no Brasil: um ponto de vista em defesa de cotas. In: SILVA, Petronilha Beatriz Gonçalves e, SILVÉRIO, Valter Roberto (Org.). Educação e ações afirmativas: entre a injustiça simbólica e a injustiça econômica. Brasília: Instituto Nacional de Estudos e Pesquisas Educacionais Anísio Teixeira, 2003.

2004.

Identidade étnica, poder e direitos humanos. Thot, São Paulo, n. 80, p. 19-30, abr.

Algumas considerações sobre "raça", ação afirmativa e identidade negra no Brasil: fundamentos antropológicos. Revista USP, São Paulo, n. 68, p. 47-57, dez./fev. 2005-2006.

. Os descendentes de africanos escravizados no Brasil na atualidade: realidades e problemas. Trabalho apresentado à International Conference on the Siddis of India and the African Diasporas in Asia, 2006, Goa.

. Política de Ação Afirmativa no Brasil: Consenso e Desacordo na Política de Cotas na Universidade Pública. In: RePetto, Maxim; Neves, Leandro Roberto; Fernandes, Maria Luiza (Org.). Universidade inconclusa: os desafios da desigualdade. Boa Vista: Editora da Universidade Federal de Roraima, 2008.

OPPENHEIMER, David Benjamin. Understanding Affirmative Action. Hastings Constitutional Law Quarterly, San Francisco, v. 23, p. 921-997, Summer 1996. 
. Why France Needs to Collect Data on Racial Identity... In a French Way. Hastings International and Comparative Law Review, San Francisco, v. 31, p. 735-751, Summer 2008.

PeCZENIK, Aleksander. Taking Laws Seriously. Cornell Law Review, Ithaca, v. 68, p. 660684, 1982-1983.

. On Law and Reason. Dordrecht: Springer, 2008.

PereirA, João Baptista Borges. Racismo à brasileira. In: MunAngA, Kabengele (Org.). Estratégias e Politicas de Combate à Discriminação Racial. São Paulo: Editora da Universidade de São Paulo, 1996.

PIOVESAN, Flávia. Implementação do direito à igualdade racial. Revista de Direitos Difusos, [S.1.], v. 9, p. 1123-1131, out. 2001.

. Ações afirmativas da perspectiva dos direitos humanos. Cadernos de Pesquisa, São Paulo, v. 35, n. 124, p. 43-55, jan./abr. 2005.

Ações afirmativas e direitos humanos. Revista USP, São Paulo, n. 69, p. 37-43, mar./mai. 2006.

. Direito Internacional dos Direitos Humanos e Igualdade Étnico-Racial. In: ; SouZA, Douglas Martins de (Coord.). Ordem Jurídica e Igualdade Étnico-Racial. Brasília: Secretaria Especial de Políticas de Promoção da Igualdade Racial, 2006.

Ações afirmativas no Brasil: desafios e perspectivas. In: CAMARGO, Marcelo

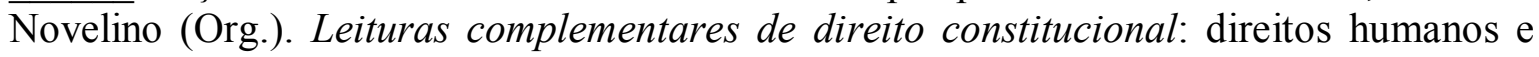
direitos fundamentais. $3^{\text {a }}$ ed. Salvador: JusPodivm, 2008.

; PIOVESAn, Luciana; SATO, Priscila Kei. Implementação do direito à igualdade. Cadernos de Direito Constitucional e Ciência Política, São Paulo, a. 5, n. 21, p. 139-145, out./dez. 1997.

PoIRIER, Marie-Pierre. Ações afirmativas e avanços sociais. Folha de S. Paulo, São Paulo, 4 abr. 2010. Caderno Brasil, p. 3. 
ProulX, Daniel. L'objet des droits constititionnels à l'égalité. Les Cahiers de Droit, Québec, v. 29, n. 3, p. 567-598, sept. 1988.

PRUDENTE, Eunice Aparecida de Jesus. Preconceito racial e igualdade jurídica no Brasil: a cidadania negra em questão. Campinas: Julex, 1989.

Experiências integradoras que o Brasil já conheceu: uma análise jurídica sobre a exclusão social dos afro-descendentes numa ordem constitucional integradora. In: Durham, Eunice R.; Bori, Carolina M. (Org.). Seminário: O Negro no Ensino Superior. São Paulo: Núcleo de Pesquisas sobre Ensino Superior, 2003.

Pulido, Carlos Bernal. Estructuras y límites de la ponderación. Doxa: cuadernos de filosofía del derecho, Alicante, n. 26, p. 225-238, 2003.

RAWLS, John. Collected Papers. Cambridge: Harvard University Press, 1999.

RochA, Carmen Lúcia Antunes. Ação afirmativa: o conteúdo democrático do princípio da igualdade jurídica. Revista de Informação Legislativa, Brasília, a. 33, n. 131, p. 283-295, jul./set. 1996.

RoDRIGUES, João Jorge Santos. Direito e ação afirmativa: as políticas de ação afirmativa para afro-brasileiros. Dissertação (mestrado em Direito e Estado), Faculdade de Direito, Universidade de Brasília, Brasília, 2005.

Rosenfeld, Michel. Affirmative Action, Justice, and Equalities: a Philosophical and Constitutional Appraisal. Ohio State Law Journal, Columbus, v. 46, p. 845-924, 1985.

Rossouw, Johann. "Embauche équitable" pour les sud-africains. Le Monde diplomatique, Paris, a. 54, n. 638, p. 13, mai 2007.

SARMEnTO, Daniel. Direito Constitucional e Igualdade Étnico-Racial. In: PIOVESAN, Flávia; SouZA, Douglas Martins de (Coord.). Ordem Jurídica e Igualdade Étnico-Racial. Brasília: Secretaria Especial de Políticas de Promoção da Igualdade Racial, 2006.

. A igualdade étnico-racial no direito constitucional brasileiro: discriminação "de facto", teoria do impacto desproporcional e ação afirmativa. In: CAMARGO, Marcelo Novelino (Org.). Leituras complementares de direito constitucional: direitos humanos e direitos fundamentais. $3^{\text {a }}$ ed. Salvador: JusPodivm, 2008. 
SCHLINK, Bernhard. Der Grundsatz der Verhältnismäßigkeit. In: BADURA, Peter; DREIER, Horst (Edit.). Festschrift 50 Jahre Bundesverfassungsgericht. Tübingen: Mohr Siebeck, 2001 .

SCHOLLER, Heinrich. Die Interpretation des Gleichheitssatzes als Willkürverbot oder also Gebot der Chancengleichheit. Berlin: Duncker \& Humblot, 1969.

Schwabe, Jürgen; MARTins, Leonardo. Cinqüenta Anos de Jurisprudência do Tribunal Constitucional Alemão. Tradução Beatriz Hennig et. al. Berlin: Konrad Adenauer Stiftung, 2005.

SCOLeSE, Eduardo. País terá mais negros que brancos neste ano. Folha de S. Paulo, São Paulo, 14 mai. 2008. Caderno Cotidiano, p. 1.

SEgATO, Rita Laura. Cotas: por que reagimos? Revista USP, São Paulo, n. 68, p. 76-87, dez./fev. 2005-2006.

SELL, Sandro Cesar. Ação afirmativa e democracia racial: uma introdução ao debate no Brasil. Florianópolis: Fundação Boiteux, 2002.

Silva, Alexandre Vitorino. O desafio das ações afirmativas no direito brasileiro. Jus Navigandi, Teresina, a. $7, \quad$ n. 60, nov. 2002. Disponível em: $<$ http://jus2.uol.com.br/doutrina/texto.asp?id=3479>. Acesso em: 13 de maio de 2006.

Silva, Maria do Socorro da. Ações afirmativas para a população negra: um instrumento para a justiça social no Brasil. Dissertação (mestrado em Direito), Faculdade de Direito, Universidade de São Paulo, São Paulo, 2009.

Silva, Ricardo Perlingeiro Mendes da. Teoria da Justiça de John Rawls. Revista de Informação Legislativa, Brasília, a. 35, n. 138, p. 193-212, abr./jun. 1998.

Silva, Sidney Pessoa Madruga da. Discriminação Positiva: Ações Afirmativas na Realidade Brasileira. Brasília: Brasília Jurídica, 2005.

Silva, Virgílio Afonso da. O proporcional e o razoável. Revista dos Tribunais, São Paulo, a. 91, n. 798, p. 23-50, abr. 2002.

. Princípios e regras: mitos e equívocos acerca de uma distinção. Revista LatinoAmericana de Estudos Constitucionais, Belo Horizonte, n.1, p. 607-630, jan./jul. 2003. 
- O conteúdo essencial dos direitos fundamentais e a eficácia das normas constitucionais. Revista de Direito do Estado, Rio de Janeiro, a. 1, n. 4, p. 23-51, out./dez. 2006.

. A constitucionalização do direito: os direitos fundamentais nas relações entre particulares. São Paulo: Malheiros, 2008.

Direitos fundamentais: conteúdo essencial, restrições e eficácia. $2^{\mathrm{a}}$ ed. São Paulo: Malheiros, 2010.

SKRENTNY, John. L' "affirmative action" américaine en déclin. Le Monde diplomatique, Paris, a. 54, n. 638, p. 14, mai 2007.

Sowell, Thomas. Affirmative Action Around the World: an Empirical Study. New Haven: Yale University Press, 2004.

StRAUSS, David. The Illusory Distinction between Equality of Opportunity and Equality of Result. In: Devins, Neal; DOUglas, Davison (Edit.). Redefining Equality. New York: Oxford University Press, 1998.

Sundfeld, Carlos Ari. Direito Público e Igualdade Étnico-Racial. In: PIOVESAN, Flávia; SouZA, Douglas Martins de (Coord.). Ordem Jurídica e Igualdade Étnico-Racial. Brasília: Secretaria Especial de Políticas de Promoção da Igualdade Racial, 2006.

TORRE, Massimo la. Constitutionalism and legal reasoning. Dordrecht: Springer, 2007.

TUORI, Kaarlo. Fundamental Rights Principles: Disciplining the Instrumentalism of Policies. In: MENÉNDEZ, Augustín José; ERIKSEN, Erik Oddvar (Edit.). Arguing Fundamental Rights. Dordrecht: Springer, 2006.

United Nations Development Programme. Human Development Report 2000. New York : Oxford University Press, 2000.

VIDAL, Dominique. Um faux débat à la française. Le Monde diplomatique, Paris, a. 54, n. 638, p. 15, mai 2007. 
VIEIRA, Andréa Lopes da Costa. Políticas de educação, educação como política: observações sobre a ação afirmativa como estratégia política. In: SILVA, Petronilha Beatriz Gonçalves e; SILVÉRIO, Valter Roberto (Org.). Educação e ações afirmativas: entre a injustiça simbólica e a injustiça econômica. Brasília: Instituto Nacional de Estudos e Pesquisas Educacionais Anísio Teixeira, 2003.

VIGO, Rodolfo. Balance de la teoría jurídica discursiva de Robert Alexy. Doxa: cuadernos de filosofía del derecho, Alicante, no 26, p. 203-224, 2003.

VILAS-BÔAS, Renata Malta. Ações afirmativas e o princípio da igualdade. Rio de Janeiro: América Jurídica, 2003.

ZuCCA, Lorenzo. Conflicts of fundamental rights as constitutional dilemmas. In: BREMS, Eva (Edit.). Conflics between fundamental rights. Antwerp: Intersentia, 2008. 